

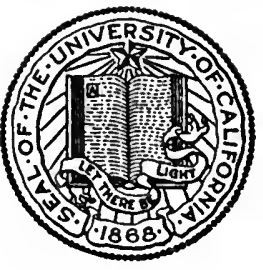

THE LIBRARY OF

THE UNIVERSITY OF CALIFORNIA

LOS ANGELES

Gift of

Dr. Roy Van wart 
Digitized by the Internet Archive in 2007 with funding from Microsoft Corporation 
. 


\title{
CRIMINAL RESPONSIBILITY
}

\author{
AND \\ SOCIAL CONSTRAIN'T
}




\section{-}




\section{CRIMINAL RESPONSIBILITY}

AN D

\section{SOCIAL CONSTRAINT}

\section{BY \\ RAY MADDING McCONNELL, Ph.D.}

INSTRUCTOR IN BOCIAL ETHICS, HARVARD UNIVERSITY, A UTHOR OF "THE DUTY OF ALTRUISM"

NEW YORK

CHARLES SCRIBNER'S SONS

1912 
Copyriget, 1912, BX CHARLES SCRIBNER'S SONS

Published March, 1912

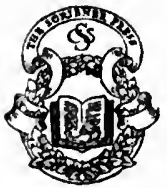




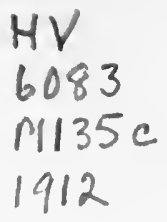

\section{CONTENTS}

\section{PART I.-THE AIM OF PUNISHMENT}

CHAPTER

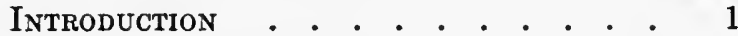

I. Punishment for Expiation • . . . . 6

II. Punishment for Retribution - • • 22

III. Punishment for Deterrence • • • 60

IV. Punishment for Reformation . - • 86

V. Punishment for Social Utility . . . 113

\section{PART II.-FREEDOM IN CRIME}

VI. Statement of Opposed Views . . . . 127

VII. The Psychology of Will, Motive, and Choice . . . . . . . . . . 135

Vili. The Nature of Mental Causation . 152

IX. Conception of Freedom Synonymous with Ignorance of Causes . . . . . 177

X. Determinism Assumed in Daily Life and in Scientific Procedure . . . . 183

XI. Concerning the "Testimony of SelfConsciousness" . . . . . . . 191 
CHAPTER PAQE

XiI. Freedom as Absence of External ConSTRAINT . . . . . . . . . 202

XIII. Character and Environment . . . 210

XIV. Determinism Not Essentially MaterialISTIC or Fatalistic . . . . . . . 219

XV. Reward and Punishment . . . . . . 228

XVI. The Nature of Laws . . . . . . . 239

XVII. Transcendental Freedom . . . . . . 258

\section{PART III.-RESPONSIBILITY FOR CRIME}

XVIII. Early Extremes and Present Practices 261

XIX. Arguments for Complete Irresponsibility of All Criminals . . . . . . 271

XX. Contrast of Moral Considerations and Soctal EXPEDIENCY • • • • . . 290

XXi. Assertion of the Criminal's Social ReSPONSIBILITY . . . . . . . . . . 296

XXII. The Basis of Personal Accountability 310 XXIII. The Basis of Social Constraint . . . 322 XXIV. Practical Procedures. Conclusion . . 333 


\title{
CRIMINAL RESPONSIBILITY
}

\author{
AND \\ SOCIAL CONSTRAINT
}





\section{PART I}

\section{THE AIM OF PUNISHMENT}

\section{INTRODUCTION}

Among the most expensive functions of government is that which is concerned with the detection, arrest, trial, and punishment of criminals. The expenditures in connection with police, courts, and prisons exceed in amount the outlay for the conservation and improvement of health, the necessities and conveniences of travel and intercourse, highways, parks, and playgrounds, and about equal the costs of education. ${ }^{1}$

When any one begins to philosophize about the raison d'être of this enormously expensive arrangement for dealing with crime and criminals, he naturally asks first for its purpose-What is the object of it all? What kind of return does this investment bring in? Society has schools for the ignorant. It has accident stations, ambulance corps, dispensaries, and hospitals for the injured and diseased. It has special educational institutions for the feebleminded, the blind, the deaf, and the dumb. It has homes for the aged, the infirm, and the incapacitated.

'Cf. Spalding, "The Money Cost of Crime," in Journal of the American Institute of Criminal Law and Criminology, May, 1910, pp. 86-102; and Eugene Smith, "The Cost of Crime," in Proceedings of the Annual Congress of the National Prison Association, 1900, pp. $308 \mathrm{ff}$. 
It has asylums and hospitals for the epileptic and the insane. But for the criminals, society has detectives, bureaus of criminal identification, police, judges, jailers, and executioners - houses of correction, penal colonies, jails, penitentiaries, the gallows, and the electric chair. What is the ground for the difference in treatment that is accorded to this last class?

Society has been treating criminals in very definite ways for quite a long time, and has been to almost infinite pains and expense to treat them precisely so. Hence it is perfectly reasonable to suppose that society must have some very specific reason for such methods. Perhaps the reason is so clear that any and every man could state it in few words. Let us make the experiment, and ask of a few men what object society has in view in its dealings with the criminal.

The lawyer replies that punishment is to compensate for damage, and to prevent further damage. The sociologist says that it is to restore the social equilibrium that has been disturbed, and to prevent further disturbance. The psychologist maintains that it is to work on the memory and imagination both of the person punished and of others who may learn of it, so that the crime may not be repeated. The moralist holds that it is to make the culprit see the error of his way, and to awaken his feelings of remorse and penitence, so that he may be converted into a good man. The priest declares that it is to expiate for sin, to make atonement to the moral governor of the universe through the sufferings of the guilty sinner. The physician says that it 
is to eradicate a plague-spot in the mind of the criminal, to prevent further spreading of the plague and the risk of social infection. The eugenist believes it a means of purifying the human race and of creating and maintaining the best social type, by rooting out the elements that have degenerated. The policeman affirms that it is to instil in the minds of the person punished and others who see his example a proper fear of those persons who make and enforce the laws. The soldier regards it as a public rejoicing over an enemy of the general interest, peace, and authority, who is at last overcome and mocked. The criminal himself considers it a fee stipulated by the power which protects the evil-doer against excess of revenge from the person injured a compromise which society accomplishes between the right of the person injured to take revenge and the right of the wrongdoer for social protection. The injured person looks on it as a payment by the injurer to the injured in some form or other, most frequently in the form of gratified feeling at seeing the damage-doer suffer in his turn.

These examples are enough to show how diverse are the opinions and how vague is the general idea concerning the specific object of punishment. There seems no general agreement as to whether punishment is retrospective or prospective-whether it is intended to requite the past or to mould the future.

If it be thought that the vagueness and diversity in these answers are due to the fact that we did not consult especially the experts whose chief concern is with punishment, a little investigation will show that this is not the case. Our legal statutes are 
indeed far removed from casual human sentiment. They are elevated above the whims, prejudices, and crude opinions of individuals. The law is supposed to have a definite purpose back of its prescriptions. But the learned doctors of the law really differ among themselves on this point as radically and fundamentally as do any other persons. A careful observer is soon forced to realize that the theories of criminal punishment current among our judges and legislators have assumed neither a coherent nor a stable form, and that the corresponding practical applications of punishment must be regarded as experimental and transitional.

This diversity and vagueness are to be accounted for by the fact that punishment is not a specially manufactured instrument, designed for a certain purpose, but is a complex social growth, having persisted through the changes of ages, places, and races. For thousands of years it has been developing, gathering accretions in some parts, undergoing dissolution in other parts, and all the while becoming more and more heterogeneous though more and more closely integrated.

Nevertheless, like all other social phenomena, it is subject to approach by science and philosophy. Science may investigate its origin and development, its place and functions in social life. Philosophy may consider its rationality, its right to continue in existence and to be consciously employed by society to accomplish its deliberate intentions. Now that human societies have become self-conscious and selfgoverning, their actions are in part at least subject to the control and direction of ideas. If a society 
conceives the notion that social punishment should never be designed to accomplish a certain purpose - to expiate religious sin, for example-then the cessation of punishment for that reason is sure to result as fast as the inertia of long-fixed social habits may be overcome.

All the variations in the object of punishment may be reduced to four fundamental types-expiation, retribution, deterrence, and reformation. The first part of this book will be devoted to a scientific weighing of the social merits and demerits of these ideas. Any prejudices derived from religious or moral partisanship should be absolutely dis-. carded. The investigation should be directed by a wholly scientific mind and by purely social considerations. 


\section{CHAPTER I}

\section{PUNISHMENT FOR EXPIATION}

\section{Statement of Theory}

WE are now to undertake a search for a satisfactory purpose in punishment. It would be well to have in mind from the start a precise understanding of what punishment is. It is definite suffering inflicted by, or in the name of, society upon an offending member. The intentional infliction of pain is an essential element. Treatment of the criminal by means of hypnotism, drugs, baths, and massage could not be called punishment.

The first view which we are to consider is that which regards the object of punitive treatment as the expiation of moral wrong or religious sin. This view may be summarized in a few paragraphs.

The moral order has been injured by the crime, and suffering on the part of the wrongdoer is the means of expiating the fault. The violated sanctity of the moral law can be repaired only through chastisement of the violator. The "ethical balance" or "moral equilibrium" of the universe has been disturbed by the act of the criminal, and can be restored only through his suffering. "Punishment is, in its essence, a rectification of the moral order of which crime is the notorious breach."1 Or, in

'Seth, "Ethical Principles," p. 317. 
Hegel's words, "Wrong negatives right, but wrong negatives the negation." ' Just human punishment avenges wrongs against the moral law, not from feelings of human vindictiveness, but as representing that which is the foundation of the universe. The moral law which the criminal has outraged asserts itself against him, to make him realize that he has done wrong, and to expiate his offence.

The general feeling of right and justice has been disturbed by the wrong, and can be set at rest only by the knowledge that the merited punishment has been received. Everywhere must exist an active consciousness and realization that guilt is an evil which reacts upon the guilty. Suffering expiates guilt-that is, it satisfies the general moral consciousness of mankind. The sinful individual will has offended against the righteous universal will; it is necessary, in the very nature of the moral universe, that expiation be made and bear a quantitative correspondence with the guilt-the greater the guilt, the greater the suffering.

That punishment must be, above all else, an expiation for past fault is proved by society's minute precautions to apportion the penalty as exactly as possible to the gravity of the crime. This endeavor is explicable only on the principle that the culpable ought to suffer because of, and in proportion to, his wrong. Considered in itself, that is, entirely apart from social interests and usefulness, punishment of wrong is just. Its justice consists in the fact that there is in the very nature of the moral universe a necessary relation between guilt and pain. The 
guiding principle is that offences should be punished according to the badness of character they imply. This is the explanation why the poisoner is dealt with more severely than the adulterator-the harmful social effects of the adulteration may be more widespread and detrimental, but the character of the poisoner is the more heinous. The builder of unsafe bridges and the insurer of dangerous houses may cause greater social damage than the assassin, but they are adjudged morally superior to him and are subjected to milder penalty. The ravisher shows greater moral depravity than the professional enticer of maidens, although the amount of social injury may be less, hence his treatment is the more stern. The death penalty cannot be explained on the basis of being intended for the criminal's reformation-it is a testimony in favor of the view that punishment is to give the offender what he deserves for having violated the sanctity and majesty of the law. What is achieved may be simply and solely the actual suffering. This shows that it was a medium to expiate guilt. "By his suffering he expiates his wrong, and appeases the rightful indignation of the law which he has transgressed." 1

Crime is primarily and essentially an offence against God, who demands the chastisement of the offender as the appropriate expiation. The fundamental aim of punitive dealing is moral atonement. The criminal is made to undergo suffering out of the recognition of the obligation to expiatory sacrifice to the injured sanctity of the divine law. The function of the worldly authorities, deriving their sanc'Alexander, "Moral Order and Progress," p. 332. 
tion and their power from on high, is to adjust suffering to sin. The criminal is, from the religious point of view, a being impure, unclean, wicked, sinful, a moral leper. The punishment imposed upon him is to be regarded in the character of a penance imposed by a priest of God, in order to make expiation and atonement. It is absolutely necessary and reasonable. To deal with a physical leper in the same way as with a healthy person would be absurd; similarly, it would be unreasonable to treat a sacrilegious and morally tainted person like one whose heart and hands are pure.

God, in his absolute justice, cannot allow one guilty sinner to escape; else his authority would crumble; his subjects would see that his rule was based on favoritism and partiality; and revolt would shake to its foundations the firmament of heaven and earth. If the moral governor of the universe should permit one wrong act to go unpunished and unexpiated, then the whole moral universe would tumble to pieces, and the world would become the abode of demons. The divine law and authority can be upheld only through punishing the guilty.

Human law is, or should be, but a replica of the divine law. Hence human punishments can have no higher or different aim than that of upholding the sanctity of the divine law, and of seeing to it that when this has been violated by crime and sin the violation shall be expiated by the suffering of the guilty. 


\section{Objections to Theory}

To administer punishment for the object of expiating moral or religious guilt is an impossible task. The principle that the penalty inflicted on the criminal must be made proportional to the wickedness of his character cannot be accomplished by human administrators of justice. They would have to penetrate into the will and measure its badness in order to know how much pain to inflict as an offset. But the thoughts of man are not open to other men. What judge is able to inspect the heart and to estimate the amount of moral depravity there, and is entitled to speak in the name of God and say that a certain amount of suffering is due as expiation? He would have to be able to foreknow the inward feelings of each individual prisoner throughout the whole period of his imprisonment, and to determine in advance what length of time in prison would be exactly a sufficiency of pain to satisfy, for atonement, the offence which had been experienced by God. Civil punishments cannot be meted out as God's justice. Legal penalties must be concerned only with the social significance of acts, motives, and dispositions. They must have no concern with the intrinsic or extrasocial qualities, such as the moral and religious character of the heart. The state must not punish the criminal for immoral or irreligious deeds, as such, but for anti-social deeds. Legislators and judges must not regard themselves as adjusters of the derangements in the moral order, but as guardians of the social well-being. Punishment must be considered as ad- 
ministered, not to "a moral and religious reprobate," but to a social damage-doer-an incendiary, a forger, a burglar, an assassin.

This theory maintains that the crime which implies the greatest moral depravity should be visited with the punishment that involves most pain to the sufferer. But no tribunal is capable of making the pain of punishment proportionate in each case to the depravity of the crime. In the first place, the degree of moral turpitude in an act is unascertainable. It depends on motives and on the general character of the agent. No one can calculate exactly the moral quality of his own acts. Much less can a judge or jury measure the moral value of an act of an unknown criminal. In the second place, no punishing authority can regulate the amount of pain caused to the culprit. The degree of suffering experienced in a particular case depends upon the temperament and circumstances of the person, which cannot be ascertained. Still further, this theory entertains a false view of the relation of the state to morality, implying that it is the business of the state to punish wickedness, as such. But the state has no such business. It has no concern with the moral depravity of the criminal. It can punish only in its capacity as the sustainer of social rights. Punishment is founded essentially on the relation of a man's conduct to the security and freedom of other members of society. Its kind and amount are determined by considerations wihich are prospective rather than retrospective. It cannot undo the harm that has been done, but it can make less likely a repetition of the injury. Its object, 
therefore, is to make the criminal suffer, not for the sake of the suffering, but in order to associate such terror with the contemplation of the crime, either by himself or others, that the terror will restrain from the crime. There is no reference to moral good or evil. The state in its punitive dealings with criminals looks not to individual virtue and vice but to social rights and wrongs. It aims to protect society. This object is in the main attainable; but the object of making the pain of punishment commensurate with the guilt of the criminal is not attainable. ${ }^{1}$

In man there is a tenacious sentiment, making it psychologically impossible for him to rest content with virtue unrewarded and vice unpunished. Man is moral by nature; he will not believe that the last word is to be with the bad, and that evil and injustice are to triumph over good. But we need to realize that this sentiment has a purely social and earthly origin, development, and utility. Man's nature is such as has been furnished him by heredity and environment, evolution and natural necessity. His system of punishment has been developed under the necessities of social life and intercourse. It should be recognized for what it is, a purely human institution and instrument. It should not be regarded as of use in the service and worship of the gods.

Punishment for expiation alone is without any social utility, and, being administered out of regard for the past, is futile. It cannot make the

"Cf. T. H. Green, "Principles of Political Obligation," "Works," vol. II, paragraphs 192, 193, 196, 197, 204. 
past any different, or cause that what has happened shall not have happened. Just punishment must be administered out of regard for the future.

Evil cannot be expiated with evil. We cannot neutralize one ill by the addition of another. For people to be morally bad is enough of evil without the addition of physical pain. Inflicting suffering for the suffering's sake is a mere triumphing over wrong by wrong, though in the name of good. Any pain inflicted by society which is not an act of goodwill and intended to do good is blameworthy. At the basis of the view which regards the object of penalty as expiation there lies a demand for the suffering of the victim-not for the sake of the feelings of the avenger, not for the sake of protecting society from harm, not for the sake of bettering the sufferer, but solely in order that suffering may exist for its own sake. The single point of view is that he who does wrong deserves to suffer for it. The whole collection of these old views should be thrown away together-free wickedness, the social demerit of personal badness, and punishment as expiation.

Kant's doctrine that punishment is "the logically necessary consequence of wrong," and "is demanded by the categorical imperative," is empty formalism, and must be rejected by all who maintain that a law is valid, not because it is a "formal" imperative, but because it has a "content" of empirical good. Similarly, no real meaning can be given to Hegel's dictum that "wrong negatives right, but punishment negatives the negation." How can punishment affect the past and make naught what has been? If his dictum does not mean this, does it mean simply 
that "even if wrong did happen, it ought not to have happened"? Is society arresting, fining, imprisoning, hanging, and electrocuting criminals simply in order to illustrate such a tautologous statement? Carried out to its logical conclusion, this view maintains that punishment would be just even though it had absolutely no social effect, and could have none, in the very nature of things. But let us exercise a little common-sense and realize that thieves would not be lodged in jails and penitentiaries if that did not prevent them from stealing and deter others from theft. Society would not go through the enormous expense of building and maintaining prisons if the existence of such institutions had no influence upon the commission of crime. It would not inflict punishment for the sake of "manifesting and abrogating the wrong that has been done." 1

In determining punishment we simply cannot fix our attention upon how much suffering is the rightful equivalent for the badness of character that has been revealed, and neglect the question concerning the effects of the treatment. Science is to ascertain, not how many days or years in jail "ought" to be imposed as the expiation for the wrong done, but the kind and amount of penalty requisite to prevent crime and protect society. Our legislators and judges are not called on to decide what suffering will "make manifest the wrong" and "satisfy the idea of the right." They are to determine what punishment will hinder crime and work for the good of society. "Justice" is, and must perforce be, a social term; and there is no justice in the infliction

${ }^{1} C f$. Paulsen, "System der Ethik," Bd. I, S. 145-147. 
of suffering for no social purpose. No social justification can be found for the view which holds that "there is a natural affinity between the two ideas of guilt and punishment, which makes it intrinsically fitting that wherever there has been wrong pain should be inflicted by way of expiation."

None of the advocates of the expiation theory of punishment would admit that the diverse faculties of man are linked together, so that the will may be regarded as the product of the sensibility. Now since, in their opinion, the sensibility is not the real centre of the human being, it is difficult to comprehend why they would hold it responsible for the badness of the will. If the will has freely chosen wrong-doing, it is not the fault of the sensibility. To add a physical evil to the moral evil, under pretext of expiation, is only doubling the sum of evil without remedying it at all. Without the justification of social necessity, punishment would be as blamable as crime; and legislators and judges, in striking the culpable, would be their equals. When abstraction is made of its social utility, what difference is there between murder committed by the assassin and murder committed by the sheriff? The latter has not even the justification of personal interest or vengeance. The legal murder would be more absurd than the illegal murder. It is impossible to see in "expiation" a sanction which is at all a rational consequence of crime.

When one speaks of "the moral order" as having been "troubled by a rebellious will," and as needing to be re-established by the suffering of the rebel, one is entirely outside of the social question and the 
proper sphere of social punishment. But looking at the matter a moment ourselves from this extrasocial point of view, we remark that it is repugnant to say that moral wrong can be repaired by bodily pain, and that the price of a morally wrong act can be paid with a certain amount of physical suffering - a purchase of "indulgences," as it were. No, the moral evil remains, in spite of any physical pain which can be added to it.

According to the champions of the expiation theory, moral evil is a sin of the free-will, altogether undetermined by the sensibility. It is as if one pan of a balance-scale were in the moral world, the other in the world of sense. In the one is the free-will; in the other is the sensibility. When the balance is disturbed by the wrong act of the free-will, the addition of suffering to the sensibility is expected to restore the equilibrium. But if the will is free, it cannot be seized or punished, it remains altogether unaffected by the suffering of the sensibility. It can be punished only if it wills to punish itself, for its badness. It can do this only in case it has already so profoundly changed for the better that it no longer deserves to be punished. Suffering cannot make expiation for wrong-doing unless it is selfinflicted and recognized by the agent as merited. This cannot be caused externally. A man may be overwhelmed with punishment and still regard it as an accidental misfortune and not as a desert. This is the antinomy of the expiation theory. As long as the sinful free-will remains sinful, it is beyond punishment and expiation. Before it can be punished and made to expiate its fault, it has to convert 
itself; and after conversion, why should it be punished? The free and sinful will is beyond the reach of punishment and beyond the possibility of a forced expiation. It is irrational cruelty when suffering is inflicted upon the innocent body of the victim; the guilty will remains unpunished and unpunishable. ${ }^{1}$

Expiation simply cannot be the object of punishment in those cases where the law diverges from ethics, as when it refuses to punish the mere intention to commit a crime, and punishes but slightly, if at all, the attempt to commit a crime. "Public opinion will sanction capital punishment when the blood of a brother man seems to cry for vengeance from the ground; it would not tolerate an execution for an attempted murder which has failed through a pistol missing fire." 2 But in intention and attempt the moral guilt may be just as great as if the wicked scheme had not happened to become frustrated. "In ethics, of course, [a vicious will] would of itself suffice to constitute guilt. . . . But there is no such searching severity in the rules of law. They, whether civil or even criminal, never inflict penalties upon mere internal feeling, when it has produced no result in external conduct. So a merely mental condition is practically never made a crime. If a man takes an umbrella from a stand at his club, meaning to steal it, but finds that it is his own, he commits no crime." 3 Looked at from the moral

\footnotetext{
${ }^{1}$ Cf. Guyau, "Esquisse d'une morale sans obligation ni sanction," pp. 190-192.

" Rashdall, "The Theory of Punishment," in International Journal of Ethics, vol. II, p. 26.

"Kenny, "Outlines of Criminal Law," revised American edition, 1907, pp. 33-34.
} 
stand-point, his intention is wicked, and may be said to need expiation through suffering. But it would be socially inexpedient and unjust to punish him. This shows that punishment is not for expiation.

That punitive affliction is aimed at social protection and not at expiation of moral iniquity is shown also by the fact that the decrees of the law sometimes differ greatly from the rules of ethics. The legal code often refuses to go with the ethical code. The state sees no social harm in some of the personal vices which moral sentiment condemns, and hence would regard it as unjust to inflict penal suffering. On the other hand, the legal code often passes beyond the moral code. The insight of the social legislators discerns evils and dangers to the general welfare not yet perceived by the common consciousness. New inventions and modern exigencies of travel and intercourse sometimes render customary forms of conduct harmful to society. Then these ways of acting are made crimes before they have had time to become wrong or sinful; and fine or imprisonment is visited upon offences which bring neither moral blame nor social shame; for example, driving on the one side of the street instead of on the other, killing game out of season, getting on or off cars while in motion. If the object of punitive treatment were expiation, it would be wrong for society to punish a person who damages it without moral guilt.

Let any one who thinks that punishment is not sufficiently justified by its being inflicted for the protection of social rights attempt to reconcile his 
sense of justice with the punishment of crimes committed in obedience to a perverted conscience. Many fanatical murderers have been executed, who regarded themselves, not as criminals, but as heroic martyrs. Were they rightly put to death? If so, the justice of their punishment had nothing to do with the expiation of badness in their minds and hearts. Their outrage of the social obligation to respect life was solely an act of self-sacrifice to what was considered a higher and more sacred obligation. They regarded their acts as possessed of sublime virtue. Out of supposed duty to God or to humanity fanatics have been guilty of the most abominable deeds, such as the assassination of rulers or the slaying of supposedly heretical enemies of God. Their punishment cannot have been justified as an expiation for internal demerit, a sinful state of mind, moral and religious guilt. Punishment for crimes of moral and religious fanaticism can be justified on no other ground than its necessity for the attainment of social ends. ${ }^{1}$

The advocates of punishment for the purpose of expiation would superimpose upon the principle of social necessity a "regulator," abstract justice, as superior to social necessity. But the only just basis of penal responsibility is that of "the dangerousness of the criminal to society." 2 The kind and amount of punishment necessary can justly be determined only by its utility.

There can be established no connection between

'Cf. Mill, "Examination of Sir William Hamilton's Philosophy," 4th edition, pp. 596-597.

"Cf. Parmelee, "The Principles of Anthropology and Sociology in Their Relations to Criminal Procedure," chap. V. 
the statements, "You are morally and religiously good"- "Therefore you ought to be rewarded by society"; or "You are morally and religiously bad"- "Therefore you ought to be made to suffer by society." Virtue and vice are affairs of the individual conscience; and so long as they are considered apart from their social utility, any reward or punishment which they may deserve is the concern of God, and not of social administration. Society's object is to look after itself, without attempting to usurp the place of God in distributing happiness and unhappiness in accordance with moral and religious merit and demerit.

The fundamental principle of punishment is that it should be restricted to social interests. Individual liberty must not be violated by laws and penalties concerning offences against morality and religion. Man cannot be held responsible for his beliefs and personal character except by his own conscience. Society cannot rightly inflict pain except for being anti-social. For it to punish for the sake of expiating internal faults is certainly not to convince the punished one of social justice. Just civil punishment can regard only the evidence of social damage, and must not pass the limits of social utility. ${ }^{1}$

It has long been a pet notion of theology that human sinfulness will have to be expiated by misery in a future life. This woe is conceived in some cases to be eternal. The fundamental notion is that wickedness must be expiated by suffering. This theological idea of expiation was brought over into social laws and produced evil results. Human judges,

${ }^{2} C f$. Mill, "On Liberty," chap. II. 
speaking in the name of God, believed that they could penetrate both into the infinite depths of the individual will, in order to measure its malignity, and into the infinite depths of the divine will, in order to ascertain and apply its just decrees. Moreover, since expiation, and consequently penalty, had to be proportional to the crime, it was necessary to invent varieties of punishment and refinements in suffering. Such results cannot fail to occur whenever any one attempts to institute expiation for "the disturbed balance between the absolute justice of God and the absolute freedom of the human will." We ought never to pretend, in our penal laws, to apply this principle. If social punishment could be justified on no other grounds than those of the absolute immorality of the bad will and the absolute justice of expiatory suffering, then we should be entirely disarmed with reference to the criminal." 1

${ }^{1} C f$. Fouillée, "La liberté et le déterminisme," p. 38. 


\section{CHAPTER II}

\section{PUNISHMENT FOR RETRIBUTION}

\section{Explanation of Theory}

According to the retribution theory, punitive suffering is to even up, to compensate, to requite for evil done. Justice requires that the wrongdoer be paid back for his wrong-doing. If anything else happens, it lies outside of the object of punishment as such. "We pay the penalty because we owe it, and for no other reason; and if punishment is inflicted for any other reason whatever, than because it is merited by wrong, it is a gross immorality, a crying injustice, an abominable crime, and not what it pretends to be. We may have regard for whatever considerations we please-our own convenience, the good of society, the benefit of the offender; we are fools, and worse, if we fail to do so. Having once the right to punish, we may modify the punishment according to the useful and the pleasant, but these are external to the matter; they cannot give us a right to punish, and nothing can do that but criminal desert. . . . Punishment is also an end in itself. Yes, in despite of sophistry, and in the face of sentimentalism, and with well-nigh the whole body of our self-styled enlightenment against them, our people believe to this day that punishment is inflicted for the sake of punishment." "Judicial

${ }^{1}$ Bradley, "Ethical Studies," pp. 25-26. 
punishment (pona forensis) is not the same as natural (prna naturalis). By means of this latter, guilt brings a penalty on itself; but the legislator has not to consider it in this way. Judicial punishment can never be inflicted simply and solely as a means to forward a good, other than itself, whether that good be the benefit of the criminal or of civil society; but it must at all times be inflicted on him, for no other reason than because he has acted criminally. . . . He must first of all be found to be punishable before there is even a thought of deriving from the punishment any advantage for himself or his fellow-citizens. The penal law is a categorical imperative." " Where crime has been committed, loss or suffering should be inflicted upon the criminal in return for the loss or suffering which he has caused his victims, even though the punishment may not be needed as a deterrent to other persons, and even though the wrongdoer may be so hardened that no punishment could reform him or even awaken him for a moment to a sense of the wickedness of his deeds. He ought, nevertheless, to be made to suffer as a matter of retribution for his misconduct. $^{2}$

Punishment is inflicted upon the criminal as an act of justice, because he merits it. The fundamental principle of morality is reciprocity. I must give my neighbor an equivalent for what I get from him; and he has no right to take from me that for which he renders no equal return. We are to repay

'Kant, "Werke," ix, 180, 183, "Rechtslehre," \& 49.

${ }^{2} C f$. Sharp and Otto, "Retribution and Deterrence in the Moral Judgments of Common Sense," in International Journal of Ethics, July, 1910, p. 447. 
both benefits and injuries on the same basis. ${ }^{1}$ The law of retaliation is well stated in the law of Moses: "Thou shalt give life for life, eye for eye, tooth for tooth, foot for foot, burning for burning, wound for wound, and stripe for stripe." "The principle that punishment should be merely deterrent and reformatory is, we think, too purely utilitarian for current opinion. That opinion seems still to incline to the view that a man who has done wrong ought to suffer pain in return, even if no benefit result to him or to others from the pain; and that justice requires this." 2

Some light is thrown on the purpose of punishment when we consider the process in which the judicial penal system developed out of the previous systems of private revenge and lynch-law. As long as retaliation was in the hands of private individuals, there was no guarantee either that the offender had to suffer or that the act of retaliation was sufficiently discriminate. On the one hand, the injured party may have been too weak, or otherwise unable, to avenge himself. His readiest course then was an appeal to the chief or the entire community for help. On the other hand, the sympathy naturally felt for the object of an improper and immoderate revenge undoubtedly tended also to bring about the establishment of a central judicial and executive authority. Indiscriminate revenge had to be restricted by referring the case to a judge who was less partial, and more discriminating, than the sufferer himself or his friends. Besides the desire that the offender

${ }^{3} C f$. Wines, "Punishment and Reformation," pp. 31-32.

"Kenny, op. cit., p. 30. 
should suffer and the desire that his suffering should not exceed his guilt, there was a third factor of great consequence which contributed to the substitution of regulated punishment for revenge and to the rise of the judicial organization. This was the necessity of maintaining the general peace. For every society it was a matter of great importance to have peace between its various members. At first, of course, every man took care of his own property and guarded his own life. If he received an injury, he retaliated or sought such redress as was possible. Though this system of private revenge helped to keep down crime, it also had a tendency to cause disturbance and destruction. Any act of vengeance which went beyond the limits fixed by custom called forth retaliation in return, and the disturbance constantly grew and extended in the community. Blow brought blow, revenge bred revenge. A whole series of murders took place. Society was afflicted with chronic feud and disorder. The state of affairs was literally a state of private war. Such a condition was incompatible with public well-being, and was injurious to society as a whole.

So, by slow degrees, private revenge yielded to social punishment. The infliction of retributive injury, forbidden to the individual, was simply transferred to the group. Society, being impersonal, could strike without provoking counter-stroke. Law gradually displaced private vengeance and steadily narrowed the field of self-defence. The king deemed every aggression an affront to him. The state regarded all outrages as breaches of the peace. It appropriated itself to the grievances of its sub- 
jects. All wrongs became crimes. It was the public peace that had suffered, and not A or B. Crime was a public more than a private wrong, and did greater injury to society than to the individual; the state, therefore, being the supreme sufferer from crime, was also the rightful avenger. Moreover, it was generally an inconvenient, and in large communities an almost impossible, procedure for the whole group to administer justice in common. Hence the dispensation of punishments naturally tended more and more to pass into the hands of a few leading men or one man. Thus a special authority came to be commissioned with the administration of justice. Ultimately, it is the district attorney who prosecutes the law-breaker, and not his victim. The private avenger is succeeded by the judge and the public executor of his sentence. ${ }^{1}$ Thus has triumphed the idea of a paramount, social interest in the repression of crime. The state of private war "has been superseded by one in which a third, a public and impartial authority (1) takes cognizance of offences against another individual as offences against the commonwealth; (2) apprehends the supposed offender; (3) determines and applies an objective standard of judgment, the same for all, the law; (4) tries the supposed offender according to rules of procedure, including rules of evidence or proof, which are also publicly promulgated; and (5) takes upon itself the punishment of the offender."

This brief sketch suffices to show how and why

${ }^{1} \mathrm{Cf}$. Westermarck, "Origin and Development of the Moral Ideas," vol. I, pp. 175-176, 180-183, 490-491; and Ross, "Social Control," pp. $40,120$.

${ }^{2}$ Dewey and Tufts, "Ethics," p. 456. 
organized retribution became substituted in place of individual vengeance. Crime came to be regarded, not merely as a private or personal matter, but as an offence against the community and its established authority, and calling for corporate chastisement. The most important thing to bear in mind while contemplating this historical transition from revenge to punishment is this: that the fundamental principle of retribution remains the same throughout. Even after the establishment of a judicial authority to regulate punishment, the principle is still that of returning evil for evil, and in proportionate measure. Indeed, the state, with its unrestrained power, has proved an even more terrible avenger than the individual. The most cruel and vindictive punishments that malignant ingenuity could devise have been administered under the sanction of law and in the name of justice. ${ }^{1}$

\section{Arguments in Favor of the Theory.}

THE ordinary discussion of the propriety of retribution as the aim of punishment is rather brief and dogmatic. The subject is simply dismissed with a dictum based on authority and the declaration, "Retribution is barbarous - the protection of society is the only scientific ground for inflicting pain upon a wrongdoer," or "Retribution is characteristic of the punitive ideals of primitive peoples, while deterrence and reformation are characteristic of the most highly civilized ones." Now, in the following discussion, I propose to mass on each side all the

${ }^{1} C f$. Smith, "Criminal Law in the United States," pp. 57-58. 
arguments I can find on that side, without endeavoring in the least to give the preference to either.

The sentiment of retribution is naturally strong in every one of us, and needs but a suitable occasion to manifest its tremendous force. Let us test its strength by an example. ${ }^{1}$ About a hundred years ago a shipload of emigrants was wrecked upon an uninhabited island in the Pacific Ocean, far from all trade routes. There they and their descendants have lived, unvisited by other men, until finally a ship appears to carry them back to England. At the time of the arrival of this ship there is in their prison a man who has just been sentenced to be hanged for murder. The circumstances of the crime were these: A physician, widely beloved and trusted, had been called in to attend some men who had been seriously wounded in a blood feud. Soon after, he was met on a lonely road by one of the feudists. The latter informed the physician that, in revenge for the services rendered to his enemies, he was about to kill him. The doctor pleaded for his life, not for his own sake, for he was over sixty, and, in any event, had not many more years to live, but for his wife and family. His wife was much younger than he, and his children-all daughters-were not yet grown. In reply the murderer only laughed at him, and, after rendering escape impossible with a single shot, proceeded in leisurely fashion to shoot him to pieces,

${ }^{1}$ This illustration is made by combining two examples given by Professors Sharp and Otto to students in the University of Wisconsin in order to find out what per cent. of them approved of retribution. The results are published in the International Journal of Ethics for April and July, 1910. Cf. also Kant, "Werke," ix, 180,183 , or Kant's "Philosophy of Law," tr. Hastie, pp. 195 ff. 
making the less vital parts of the body his first target in order to lengthen his victim's agony as much as possible, jeering at him all the while. Now is the community, before breaking up, its members to scatter to different parts of the world, bound to hang this murderer, or is it at liberty to set him free? It being understood: (1) that a failure on the part of the islanders to punish the crime will create no precedent which might lead to future murders by other persons; (2) that while the murder was in every respect unjustifiable, there are no grounds for the fear that the murderer, if freed, will ever commit another similar crime (the circumstance that removes the danger of the commission of a second similar crime is an accident, or an attack of paralysis, which will render him a helpless invalid for the remainder of his days, but has no causal connection with the crime); and (3) that the murderer is incorrigible, a man whom no punishment could reform or even awaken temporarily to a sense of the enormity of his guilt. He feels no compunction or sorrow of any kind at the deed; in fact, if he escapes punishment, he will feel genuine satisfaction at having committed it.

The conditions of the example are intended to make it plain that those who approve of the punishment of this man do so on what can only be grounds of retribution. Having inflicted injury upon another or others, he ought to be subjected to injury himself, as a just return. The punishment of the wicked is demanded for no other reason than the infliction of pain itself. There lies at the basis of retribution the demand for harm for its own sake. 
The judger's moral ideal demands that a person who commits certain acts shall suffer in consequence, whether his suffering subserves any other end or not.

Another example, equally strong for arousing the sentiment of retribution, may be made out of "the story of a seduction by means of a mock marriage and of the abandonment of the woman, leaving her without money, help, or friends, with the most terrible ordeal of her life immediately before her." ${ }^{1}$

Adam Smith approved of punishment on grounds of retribution. He maintained that it is justified by the fact that it satisfies men's natural resentment, a sentiment "which most immediately and directly prompts us to punish, or to inflict evil upon, another." "To punish is to recompence, to remunerate, . . . it is to return evil for evil that has been done. . . . $\mathrm{He}$, therefore, . . . appears to deserve punishment, who ... is to some person or persons the natural object of a resentment which the breast of every reasonable man is ready to adopt and sympathize with. To us, surely, that action must ... appear to deserve punishment which everybody who hears of it is angry with, and upon that account rejoices to see punished." " "I affirm, that it is not the view of ... utility or hurtfulness which is either the first or principal source of our approbation and disapprobation. These sentiments are, no doubt, enhanced and enlivened by the perception of the beauty or deformity which results from this utility or hurtfulness. But still, I say, they

${ }^{1}$ Sharp and Otto, in International Journal of Ethics, April, 1910, p. 350 .

${ }^{2}$ Adam Smith, "Theory of the Moral Sentiments," part II, "Of Merit and Demerit: or, The Objects of Reward and Punishment." 
are originally and essentially different from this perception." 1

Westermarck champions the position that punishment is, in the main, an expression of public indignation, and intended as retribution for the wrongdoing of the culprit. ${ }^{2}$ The question at issue is this: Is punishment the result of the sense of justice, or is the sense of justice the result of punishment? Are certain acts punished by the state because regarded as morally wrong and worthy of punishment; or do certain acts come to be regarded as morally wrong and worthy of punishment because they are punished by the state? He maintains that punishment always requires the sanction of the retributive emotion of moral disapproval. "Punishment, in the ordinary sense of the word, always involves an express intention to inflict pain, whatever be the object for which pain is inflicted. We do not punish an ill-natured dog when we tie him up so as to prevent him from doing harm, nor do we punish a lunatic by confining him in a mad-house. . . . First of all, moral resentment wants to raise a protest against wrong. And the immediate aim of punishment has always been to give expression to the righteous indignation of the society which inflicts it. ... Whether its voice inspire fear or not, whether it wake up a sleeping conscience or not, punishment, at all events, tells people in plain terms what, in the opinion of the society, they ought not to do. ... It must not be overlooked that the infliction of punishment upon the perpetrator of a grave

${ }^{1}$ Ibid., part IV.

${ }^{2}$ Westermarck, op. cit., vol. I, pp. 77-93, 169-201. 
offence gratifies a strong general desire. ... Retaliation is such a spontaneous expression of indignation, that people would hardly realize the offensiveness of an act which evokes no signs of resentment. ... The retributive desire is so strong, and appears so natural, that we can neither help obeying it, nor seriously disapprove of its being obeyed. . . . Since the remotest ages the aggressive attitude toward this cause has been connected with an instinctive desire to produce counter-pain; and, though we may recognize that such a desire, or rather the volition into which it tends to develop, may be morally justifiable only if it is intended to remove the cause of pain, we can hardly help being indulgent to the gratification of a human instinct which seems to be well nigh ineradicable. It is the instinctive desire to inflict counter-pain that gives to moral indignation its most important characteristic. . . . Without it, we should no more condemn a bad man than a poisonous plant. The reason why moral judgments are passed on volitional beings, or their acts, is not merely that they are volitional, but that they are sensitive as well; and however much we try to concentrate our indignation on the act, it derives its peculiar flavor from being directed against a sensitive agent." 1

Kenny also, in discussing the aim of criminal punishment, says that one purpose which the legislator may legitimately desire to attain as a result of punishment, "distasteful as is the suggestion of it to the great majority of modern writers, is the gratification of the feelings of the persons injured. In early law

${ }^{2}$ Westermarck, op. cit., vol. I, pp. 82-92. 
this was undoubtedly an object, often indeed the paramount object, of punishment. . . . The current morality of modern days generally views these feelings of resentment with disapproval. Yet some eminent Utilitarians, like Bentham (and not without support from even so dissimilar a writer as Bishop Butler), have considered them not unworthy of having formal legal provision made for their gratification. Hence, no less recent and no less eminent a jurist than Sir James Stephen maintains that criminal procedure may justly be regarded as being to resentment what marriage is to affection - the legal provision for an inevitable impulse of human nature. 'It is highly desirable,' says Stephen, 'that criminals should be hated, that the punishment inflicted upon them should be so contrived as to give expression to that hatred, and to justify it so far as public provision by means of expressing and gratifying a healthy natural sentiment can justify and encourage it.' . . . The modern community, like those ancient ones which Maine depicts, measures here its own public vengeance by the resentment which the victim of the crime entertains. The right to punish must ever remain founded, in part at least, upon the idea of retributive justice. Pain must ever follow wrong-doing. . . . It remains, therefore, not only the right, but the duty of the state, to punish those acts which are deemed subversive to society, quite apart from motives merely prudential or reformatory."

The argument of Adam Smith, Westermarck, and Kenny may be expressed briefly in the sentence,

${ }^{1}$ Kenny, op. cit., pp. 28-29. 
A sentiment which is so natural in all human nature as is the demand for retributive justice must needs be right, and worthy of being acted upon. This argument might be strengthened by extending our consideration beyond human nature to all animal nature. Retribution is instinctive in all animal life, a fact which argues for the propriety of the principle. Injure an animal, and it bites back. Even after its brain has been removed, it attempts to bite any one who injures it. This shows how deeply the instinct is inwrought into its nature. The presence of this instinct is accounted for by its having been necessary for survival in the struggle for existence. The instinct is grounded ultimately in "the will to live," which is primary in every living thing, leading it to defend itself against attack. All life is a constant overcoming of things that would hinder or destroy it. Vengeance has been biologically necessary for survival. In human nature, certain refinements in the instinct have taken place. There are marked differences in the kind and degree of reaction provoked by injury to a wild animal, a savage man, and a civilized man. The revenge of the savage and the animal attempts to pay back more than it receives. But the retribution of the civilized man attempts to be just. Justice would requite good with good, and evil with evil, and in proportionate measure. Those people who would condemn all retribution are going straight against a fundamental trait of human and of all other life, - an instinctive trait which has been called into being by the necessities of the struggle for existence, and which has received the approval of the evolutionary cosmic process. 
In order to live, in any society, it is necessary to be able to bite him who bites you, to strike him who strikes you. The individual who is incapable of returning the evil done to him is a being poorly endowed for survival, and destined to disappear sooner or later in the struggle for existence. The spirit of retribution lies so deep in human nature, that if you ask of a child, or a common man, whom you see beating some one, why he is doing it, he will consider his action fully justified if he is able to say that he was struck first. Whoever strikes another may expect, according to both natural and social laws, to be struck in return. This is true from top to bottom of the scale of life. Man comes to formulate a general law: It is natural that any one who interferes with the happiness of his fellows should in return be deprived of the means of being happy. Hence, we have, as the law of punishment, that he who does evil should receive evil in return and in corresponding measure.'

It might almost be said that retributive punishment is the order of all nature. The same relation of evil consequences to evil deeds exists when those consequences take place as the result, not of human laws, but of natural laws; as when, for example, dissolute sexual habits bring on horrible disease and suffering. ${ }^{2}$

Another argument in favor of regarding the aim of penalty to be retribution is found in the fact that punishment, in order to be recognized as just, must not be inflicted on innocent persons. For example,

${ }^{1}$ Cf. Guyau, op. cit., pp. 203-205.

"Cf. Schopenhauer, "Die zwei Grundprobleme der Ethik," S. 102. 
as the result of our knowledge concerning the working of the laws of heredity, we may feel quite sure that the children of certain parents will develop into criminals, and that the best thing society could do for its own good would be to imprison or exile these children. But such a procedure cannot take place, because it conflicts with the general sense of retributive justice. These children have done no wrong; and punishment of them could not be regarded as a just requital for wrong-doing. So it is impossible to deal with them in this manner. Punishment is not proper and just unless it is for retribution.

That moral indignation lies at the basis of penal treatment is indicated also by the fact that men cannot possibly feel the same sympathy for a criminal who suffered punishment as the consequence of his wrong-doing as for an innocent man who was punished by mistake, no matter how good deterrent effects were realized. Suppose two prisoners are being released after twenty years of imprisonment, the one having served out his term for a heinous crime of which he was the perpetrator, the other, however, having been pardoned because evidence which has just come to light proves him to be absolutely innocent of the crime with which he was charged. The sense of retributive justice allays our feeling of sympathy in the one case, while it increases it in the other.

Our laws try to find out the state of the will that lay behind the harmful act. If the deed was caused by a bad will, it is subjected to penalty; but if it was involuntary or purely accidental, it is excused. 
This shows that the object of chief consideration is the badness of the will displayed, and that the regard is toward the past. Discrimination in the treatment of harmful acts rests on the principle of retribution: society wishes to pay back evil for evil and in proportionate measure. That we should regard retribution as the proper aim of punishment is evidenced by our general recognition of the principle that punishment must be proportionate to the guilt. "Equality before the law" is a cardinal tenet of our legal faith. Two persons who commit exactly the same crime must be punished equally, no matter whether the judge is certain that for the one case a hundredth part of the punishment for the other would be just as efficacious in deterring from future crime. If the one criminal were sent to prison for one week, and the other for two years, there would arise from the people of the country a terrific storm of protest on account of the outraged sense of retributive justice. The general principle of gradation of penal suffering according to the magnitude of the crime argues for retribution as the proper basis of punishment. ${ }^{1}$

An equally significant testimony that punishment is for retribution is borne by the principle that it must not transgress the limits set down by moral disapproval. Our sense of what is morally just has established a fairly definite code of penalties, showing the relation of suffering to offence. Whenever a judge imposes a sentence that is regarded by the people generally as either too light or too severe, our sense of retributive justice is outraged, and we

${ }^{1} C f$. Durkheim, "Division du travail," pp. 93 ff. 
protest; and we are not appeased by references to reformation, deterrence, and social protection. In the case of an assassination, the great intellectual and moral value of the victim constitutes an aggravating circumstance. We are more violently indignant over the murder of a great man than over that of a drunkard or a rascal. On the other hand, courage, worth, and genius on the part of the criminal constitute an attenuating circumstance. These facts go to show that punishment has regard for the past, and is intended to pay back for wrong-doing and in proportionate measure. ${ }^{1}$

Again, it is the principle of retributive justice which accounts for the demand that offenders who are amenable to discipline and reformation must not be treated more severely than incorrigible criminals. If reformation were the proper aim of punishment, as so many people maintain, we might be led to conclude that since in the case of an incorrigible offender punishment would be absolutely useless, it should not be at all severe; but in the case of an offender whom punishment would reform it might be made to reach any degree of severity necessary to effect the reformation. It is the demand for retributive justice that shackles the ardent reformationist, and keeps even him from regarding incorrigibility as a legitimate ground for exempting a person from penalty, and corrigibility as a legitimate ground for severity.

Further, the retributive object is clearly shown by the fact that we regard it proper to punish the ac-

${ }^{1} C f$. Mruxion, "Éléments et évolution de la moralité," in Revue philosophique, 1903, pp. 1 ff., $150 \mathrm{ff}$. 
complished crime more severely than the attempt that has failed. If deterrence were the aim, the same amount of suffering would be needed to restrain from the attempt as to restrain from the actual offence. And society is equally endangered by the successful and the unsuccessful criminal, when the lack of success is due solely to mere chance. The reason for the difference in punishment is because our indignation is not so deeply stirred, and we do not see as just cause for retribution in the case of an ineffectual attempt as in the case of an accomplished crime.

The retributory aim appears in all those laws which leave it to the damaged person to decide whether the damager shall be punished or not, and what punishment (within certain limits) shall be inflicted upon him. The penalty is regarded as an indemnification to the injured party and as an expression of indignation and sympathetic resentment on the part of society.

The retributive aim is attested also by the peculiar aspect that suffering has when borne as penalty. If we told the punished culprit that he was undergoing suffering for the benefit of society, he would have a right to regard himself as a hero, a devoted martyr. But this is not what we wish him to think, and it is not our thought. Punishment always involves opprobrium. It expresses the detestation of society. The acts which the law punishes are, in general, acts which society condemns as wrong; and it is their wrongness which is regarded as the cause and justification of their being punished.

Men have always affirmed that there ought to 
be an intrinsic connection between punishment and resentment. This affirmation is recognized most clearly in the primitive law of talion-an eye for an eye, a tooth for a tooth, a life for a life, but it exists also in nearly all other laws. Since the retributive principle has received the approval of practically all peoples in all ages, it is not lightly to be rejected as improper.

\section{Arguments against the Theory}

RETRIBution is very generally condemned; but it is surprising how seldom the condemnation is supported by reasoned argument. As a rule, if a book or a teacher discusses the subject at all, there is simply an appeal to authority or a disgraceful ad hominem argument. Now, the considerations which have been massed together in favor of retribution are very powerful, and require to be met by others of equal force. In fact, the question seems rather more open to doubt than most lecturers or writers would have us believe. Let us present the various arguments against retribution with as great force as we can, realizing, however, that readers may divide in opinion as to which set is the more convincing.

The considerations against regarding punishment as retributive may be divided into three groups, according to whether they look at the matter from the stand-point (1) of the person punishing, or (2) of the person punished, or (3) of society in general. The first group of arguments condemn the sentiment of resentment and the motive of vengeance as being unworthy in the persons punishing. The second 
maintain that the criminal is a diseased person and in need of treatment rather than punishment. The third consider punishment out of regard for the past as socially useless and morally unjust. Let us look at the various arguments more in detail.

In the first place, then, the motive of punishing for retribution is unworthy of a moral person.

Those theorists who seek to justify retributive punishment on the ground that resentment is a natural instinct in man, as well as in all other creatures, are able to prove neither the legitimacy of the generalization nor the validity of the conclusion drawn. As a matter of fact, the generalization that every living thing naturally tends to return blow for blow is illegitimate. The reflex action which takes place in case of sudden attack is not always toward counter-attack. The snail draws back into his shell and remains motionless; the dove endeavors to hide herself; the gazelle attempts to flee. Among men, the same traits are often found. Archeologists agree in declaring that our primitive ancestors were endowed with piety, industrious activity, honesty, justice, and kindness. Travellers, geographers, and ethnologists testify that present-day savages are generally "good." Finally, the scientists concerned with the study of animal life tell us of the kind co-operation, mutual assistance, and heroic selfabnegation to be seen among simian families and even among ants and bees. ${ }^{1}$ In view of such testimony, we are led to doubt the correctness of the view that regards vengeance and ferocity as natural and instinctive in every living being. But, more to the ${ }^{\prime} C f$. De Quiross, "Modern Theories of Criminality," pp. 43-44. 
point, the human individual is not simply one instinct. The tendency to return evil for evil is simply one among many other tendencies; and may be entirely overcome by these others. Still further, man is guided more by intelligence and reason than by instinct. So, when he concludes that it is unreasonable and unjust to give play to the vengeful impulse, his acts follow in accordance with that conclusion.

It is characteristic of rude communities that the administration of justice is influenced by the general feeling of sympathy with the victim of wrong, and that the avenging punishment is in accordance with the impulses of the aggrieved. But the developed moral consciousness cannot regard with indifference the infliction of pain, even on a criminal. It pronounces it both unreasonable and cruel that any one should be tormented to no purpose. When suffering is inflicted, it must not be as an end in itself, but as a means of attaining some good. It must be given, not because wrong has been done, but in order that wrong may not be done. The object must be either to reform the criminal or to deter from crime and protect society. ${ }^{1}$

Plato said that a reasonable man punished either for the sake of deterring from wickedness, or with a view to correcting the offender. ${ }^{2}$ Aristotle regarded punishment as a moral medicine. ${ }^{3}$ Seneca taught that the law, in punishing wrong, aims at three ends: "either that it may correct him whom it punishes,

${ }^{1} C f$. Westermarck, op. cit., vol. I, p. 80.

${ }^{2}$ Cf. Plato, "Protagoras," p. 324; "Politicus," p. 293; "Gorgias," p. 479; "Laws," ix, 854; xi, 934; xii, 944.

${ }^{3}$ Cf. Aristotle, "Nicomachean Ethics," ii, 3, 4. 
or that his punishment may render other men better, or that, by bad men being put out of the way, the rest may live without fear." 1 Hugo Grotius maintained that "Man is not rightly punished by man merely for the sake of punishment"; advantage alone makes punishment right - "either the advantage of the offender, or of him who suffers by the offence, or of persons in general." 2

The moral inadequacy of the retributive principle was well stated by Hobbes in his "Leviathan." "A seventh law of nature is, that in revenges, that is, retribution of evil for evil, men look not at the greatness of the evil past, but the greatness of the good to follow. Whereby we are forbidden to inflict punishment with any other design than for correction of the offender, or direction of others. For this law is consequent to the next before it, that commandeth pardon, upon security of the future time. Besides, revenge, without respect to the example and profit to come, is a triumph, or glorying in the hurt of another tending to no end; for the end is always somewhat to come; and glorying to no end is vainglory and contrary to reason, and to hurt without reason tendeth to the introduction of war which is against the law of nature, and is commonly styled by the name of cruelty." 3

If the proper aim of punishment were retribution - the returning of evil for evil and in proportionate measure-how could the amount of punishment due be determined in case of such offences as perjury,

'Seneca, "De clementia," i, 22; of. "De ira," i, 19.

'Grotius, "De jure belli et pacis," ii. 20, $4 \mathrm{ff}$. Cf. Westermarck, op. cit., vol. I, pp. 80-81.

"Hobbes, "Leviathan," chap. XV. 
deception, and treason ${ }^{1}$ Must society lie to the liar, deceive the deceiver, and betray the traitor? Seneca asked wittily, "Would any one think himself to be in his perfect mind if he were to return kicks to a mule or bites to a dog?" 2

Punishment based on vengeance usually exceeds justice. Whenever the spirit of vindictiveness has ruled, retaliation has not been regulated by the principle of proportionate measure to the injury. A punishment was proportioned, not according to the magnitude of the harm, but according to the dignity and power of the person harmed. The avenger did not content himself with returning blow for blow; he was apt to be satisfied only by the death of the offender. A slight offence against the king was avenged by death. In countries where slavery existed, law and punishment treated quite differently the slave and the free man. Where one race had another under subjection, the murder of a member of the superior race was apt to be recompensed by the slaughter of a number of the members of the inferior one. In order to punish for the murder of an Englishman or a Frenchman or a German, a whole village in South Africa was liable to be burned, or an entire population massacred. The caste system in India has a penal code that is minutely regulated according to the value of the individual. Penalties for crime are arranged in direct proportion to the rank of the victim and in inverse proportion to the rank of the culpable. These facts go to show that when punishment is motived by the desire for retali-

${ }^{1}$ Cf. Wundt, "Ethik," Bd. II, S. 145.

'Seneca, "De ira," iii, $26 f f$. 
ation, it is apt to exceed the limits of equity. The spirit of vengeance is incapable of administering justice. It cannot judge calmly and wisely what measures will best serve the social interests. Vindictive legal procedure tends to carry to excess the authority of society over the individual and to violate the rights of personality.

In the superior social state in which we live, the individual has no need of defending himself. Hatred and vengeance are unjustifiable. If any one is robbed, or struck, or hurt in any way, he may complain to the police and the law, who will redress his wrongs and preserve the general social interest. ${ }^{1}$

The principle that he who injures society should be injured by society is wrong. Good acts call for good return. Bad acts call also for good return. The vicious man and the criminal, then, are not to be visited with evil as evil. The pain that may be inflicted is not to be inflicted merely as such. It is to be regarded as a means to good. As Plato said, the physician sometimes causes suffering to the patient with a view to healing or curing him. The vicious man and the criminal are to be regarded as sick, and are to be treated accordingly. Retributive justice partakes of the nature of vengeance. In its place there ought to be substituted charity or love. The final aim of all action, public as well as private, should be charity, - charity for all men, no matter what their individual value in moral, intellectual, or physical attainments. Vengeance is not a proper principle in social action. One harm cannot be evened up by the infliction of another. ${ }^{2}$

${ }^{1} C f$. Guyau, op. cit., p. $211 . \quad{ }^{2} C f$. Fouillé, op. cit., pp. 328-328. 
Man has long outgrown the stage at which the normal reparation given to the injured consisted in retribution inflicted on the wrongdoer. He once thought it as clearly right to requite injuries as to repay benefits; but now he thinks it never right to harm any one, however he himself may have been harmed. Though this is his view of resentment in individual action, he keeps the old idea of retaliation in collective action, that is, in criminal punishment. Current opinion inclines to think that justice requires that a man who has done wrong ought to suffer pain in return, even if no benefit result to him or to others. $^{1}$

The principle of retaliation could be admitted to be proper for private life, that is, for the regulation of relations between individual and individual, much more easily than for public life and state action. The state is too exalted to be able to inflict evil on an individual solely to get even with him. It cannot administer punishment to retaliate. It would itself be immoral and criminal if it attempted to requite the brutality of murder with the same brutality. Hatred and revenge are affections which should have no place in the collective will and action. That public administration of justice is, or should be, wholly free from passion constitutes its infinite superiority over private administration of justice. The public judicial decision concerning right and wrong must be above all influence from emotion. ${ }^{2}$

Punishment, even though it be severe, may be used to improve the wrongdoer and to serve as a

${ }^{1}$ Cf. Sidgwick, "Methods of Ethics," p. 280.

${ }^{2}$ Cf. Wundt, op. cit., Bd. II, S. 145. 
warning to those who might be tempted to imitate him. But brutal repression, which regards only the act and closes its eyes to the circumstances in which it was produced, is revolting to the moral conscience. Punishment is the more apt to be accepted and to prove efficacious according to the degree in which it is just and is meted out by the desire to lead back to the right way. It is sure to meet with revolt and to provoke further evil when it is dictated by the spirit of vengeance. ${ }^{1}$

Punishment under the sway of the impulse for revenge, for gratification of hatred and spite, is altogether degrading to man. It lowers the punisher to the same level with the culprit. What difference is there in intrinsic moral value between the criminal when he strikes his enemy out of hatred and the desire to make him suffer, and society when it strikes the criminal out of hatred and the desire to make him suffer? Yet this is to be the motive of penal action, according to the theory of retribution. Punishment is to have the character of a passionate reaction, a brutal gratification of vengeance. The offender must be made to smart for the sake of the pain. It is precisely the same unworthy and savage incitement which led the less civilized peoples to punish animals, infants, the relatives and friends of the offender, with never a thought of responsibility or of social utility. The one and only incentive was the desire of vengeance, of causing suffering. It is the same motive, still, in the somewhat more refined theory of punishment for retribution. This theory raises not the questions of responsibility, of deterrent p. 73 .

${ }^{1}$ Cf. DuBois, "The Psychic Treatment of Nervous Disorders," 
and reformatory effects, and of social utility. But is there any great difference between the joy of the savage as he dances around his tortured enemy and the joy experienced by us as we read of the arrest, condemnation, and punishment of a criminal?

The second group of arguments against regarding retribution as the aim of punishment look at the matter from the stand-point of the victim. They maintain, in brief, that the criminal is a diseased person needing treatment and not punishment.

The retributory aim is founded on a wrong principle. It is based on belief in freedom and responsibility. Every man is regarded as free, both in acting and in choosing. If he commits a crime, he is responsible, and should be made to suffer for it. He ought not to have done it. The degree of his badness and the amount of punitive affliction due are measured by the magnitude of the harm. The basis of reference in determining the punishment is the gravity of the crime. The criminal is lost sight of, except as being the suitable object for the chastisement decided on. This is the philosophy on which the retributive idea rests.

But science and reason have about concluded that freedom and responsibility are conceptions which cannot be used as a basis for treatment of the wrongdoer. The principle that the malefactor is such by free and deliberate choice and therefore deserves to be punished is a gratuitous assumption. A criminal act is as much an inevitable result of certain necessary causes as is a flash of lightning or an ebb of the tide. ${ }^{3}$ The criminal merits nothing but pity, certainly not cruelty.

${ }^{1}$ See part II for amplification of this idea. 
Free or not, the offender is a being endowed with intelligence. He rightly demands of the laws that they be reasonable. In consulting his reason, he ought to be able to be of the same mind as the judge who decides his punishment. Unless our laws and penalties are such that reason may be convinced of their justice, they are not different from the procedure among brutes, with whom there reigns no law but that of the strongest. "What erring human nature deserves or merits, it is just it should have. But in the end, a moral agent deserves to be a moral agent; and hence deserves that punishments inflicted should be corrective, not merely retributive. Every wrongdoer should have his due. But what is his due? Can we measure it by his past alone; or is it due every one to regard him as a man with a future as well? as having possibilities for good as well as achievements in bad? Those who are responsible for the infliction of punishment have, as well as those punished, to meet the requirements of justice; and failure to employ the means and instrumentalities of punishment in a way to lead, so far as possible, the wrongdoer to reconsideration of conduct and reformation of disposition, cannot shelter itself under the plea that it vindicates law. Such failure comes rather from thoughtless custom; from a lazy unwillingness to find better means; from an admixture of pride with lack of sympathy for others; from a desire to maintain things as they are rather than go to the causes which generate criminals." 1

The work of the Italian school of criminal anthropologists and sociologists has contributed a great

${ }^{1}$ Dewey and Tufts, op. cit., p. 417. 
deal toward establishing the opinion that the criminal is a necessary product of abnormal biological conditions and adverse social circumstances. This fact constitutes a very strong argument against the retributive notion of punishment. Morrison, in his introduction to Lombroso's "Female Offender," gives an excellent statement of this position, which may be epitomized as follows: The retribution theory rests on the belief that the criminal is such as the result of free choice, that originally his physical and mental constitution was made up of the same elements as those of the law-abiding men of the community. But this belief is erroneous. Vast numbers of the criminal population live under anomalous biological and social conditions; and it is these conditions acting upon the offender either independently or, as is more often the case, in combination, which make him what he is. Retributive punishment, however, pays little attention to these facts. It assumes that the wrongdoer was existing under the same circumstances as an ordinary man. It is administered on this hypothesis, which is fundamentally false. It would subject all offenders convicted of the same offence to the same length of sentence, the same penal treatment, the same punitive regulations in every shape and form. But the principle of equality of sentences is fundamentally erroneous. The duration and nature of corrective treatment must be adjusted to the character of the wrongdoer as well as to the nature of the wrong. In other words, judicial sentences and disciplinary affliction must be determined by the social and biological conditions of the malefactor quite as much 
as by his misdeed. According to the maxim that the punishment should be adjusted to the crime, offenders who have been guilty of the same offence should be sentenced to exactly the same penal treatment. But this maxim is departed from even now if the one culprit is a child while the other is of mature years, or if the one is a man and the other a woman, or if the one is feeble-minded while the other is perfectly sane. In these instances justice sets aside the notion that two misdemeanors of equal gravity are to be dealt with by awarding the same amount of penalty to each. But this principle of adjusting the methods of treatment to the nature of the delinquent as well as to the nature of the offence is practically ignored in all other cases. Except in glaring instances of lunacy the court takes little or no cognizance of the individual and social conditions of the transgressor. Uniformity of penal dealings rests upon the assumption that all evil-doers are of the same type and are produced by exactly the same causes. A practical acquaintance with criminals shows that this is not the fact. The criminal population is composed of many types: casual offenders who differ buit little from ordinary men; juvenile delinquents; weak-minded, insane, and epileptic offenders; drunkards, beggars, and vagrants; professional thieves, etc. It is useless applying the same method of penal correction to each and all of these classes of offenders. The treatment must be differentiated, and determined as far as practicable by the kind of type to which the criminal belongs. ${ }^{1}$

'Cf. Morrison, in introduction to Lombroso's "Female Offender," pp. viii-xx. 
Guyau gives a forcible statement of the argument based on consideration of the criminal, which may be summarized as follows: The principle of retributive justice is "To each according to his works." He who does much should receive much. He who does little should receive little. He who does evil should receive evil. Notice first that the last statement cannot be deduced from the preceding. From the proposition that the less service calls for the less recognition, it does not follow that an offence calls for vengeance. But even the two preceding propositions are contestable as formulations of the moral ideal. They confuse the moral and the social points of view. "To each according to his works" is a good working principle to regulate the economic order and social contracts; but it cannot be regarded as the standard of moral appraisal. It simply means that in economic intercourse, independently of good and bad intentions, objects should exchange for their equals in value - the individual who gives a product of considerable worth should not receive in exchange something insignificant. This is a principle of economic exchange, of interested action. It is not the criterion of disinterested action or moral virtue. In the moral realm, where the will is the principal object of consideration, and where infinite value attaches to all personality, the law of retributive justice loses its force. In the material and economic order, evil unrequited shocks us as something anti-social, a disturbing element in the social equilibrium. But in the moral order a different condition exists. That goodness should receive the approval of all, and that 
badness should receive the disapproval of all, is most rational. But moral approval and disapproval as such must not be changed into coercive and afflictive social action. To the affirmation "You are good" or "You are bad" we must not add, "Therefore we must make you rejoice" or "We must make you suffer." Virtue and vice are affairs of the individual conscience. The moral ideal would be to make all men good and happy. In accordance with this principle, criminals and wild human beasts should be treated with indulgence and pity. No matter whether their ferocity be regarded as fatal or free, they are always to be pitied. Why should we add to their moral evil a physical evil as well? In place of the narrow retributive justice, which refuses good to those who are so unfortunate as to be bad, there must be substituted a larger justice, which would give good to all, considering neither which hand gives nor which hand receives. This is the only legitimate principle from the point of view of pure morality. The criminal retains even before our own laws certain rights. Before the moral law he possesses all the rights of personality. Just as no man can sell himself into slavery, so no moral being can forfeit his right of moral attainment. To take away from any one, or to refuse to furnish to any one, the chance of attaining the moral good cannot be justified. You say that it is a sufficient reason that the criminal is bad. Is it in order to make him better that you take recourse to punishment? No; that is an end which may be attained better by some other means. Your principal aim is retribution, to produce suffering without further 
object. As if it were not already evil enough to be bad! From him that has not is taken even the little that he has. ${ }^{1}$

The third group of arguments against regarding retribution as a right principle look at the matter from the stand-point of society, and maintain that retribution is socially useless and even harmful. The only proper grounds for administering legal chastisement are out of regard for the future. When the criminal is made to suffer, it should not be on account of what he has done and because he merits suffering, but in order that he may not do anything similar in the future. Punishment is to consider, not past realities (they could not have been other than they were, and nothing done now can make them any different), but future possibilities. It is to be a force toward making the future what society desires it to be. Society has a right to restrain the liberty of a criminal only in so far as he is capable of doing further harm. If he should go voluntarily to some desert island, from which a return would be impossible, then society would be without rights over him. Its future protection would be guaranteed. It would have no right to follow him and cause him to undergo a certain amount of suffering merely for the sake of the affliction.

In fact, we may even push this principle to the extreme and yet affirm its validity. Let us suppose that the state of human affairs should become so changed that punishment would not be socially necessary, and that rewarding an offender would be a more effectual means of improving his character

${ }^{2}$ Cf. Guyau, op. cit., pp. 192-197. 
and protecting society than chastising him, then punishment would be superseded, and even the sentiment of vengeance and retribution, having no further use in the changed circumstances of mankind, would die away. ${ }^{1}$ If a term in a hospital, with liberal diet, genial company, free communication with the outside world, artistic rooms, abundant leisure, and varied amusement were found in practice to be more deterrent and more reformative than solitary confinement, a plank bed, and diet of bread and water, then who would forbid the institution of a code of graduated rewards in place of our present system of pain-giving punishments? ${ }^{2}$

The retribution theory would afflict the offender without reference to social utility. But why increase the amount of suffering in a world that is already too full of it? Considered entirely apart from its effects, there would be no moral propriety in the infliction of pain for its own sake. When a crime is committed, a double evil enters the world: the victim's pain and the criminal's moral pollution. Is the matter improved by the addition of a third evil-the pain of punishment, which by hypothesis is to do no good to the victim, the offender, or society? ${ }^{3}$

The retributive theory cannot account satisfactorily for the principle that unintentional harm is not requited. The real reason is that society recognizes that in the case of accidental or involuntary in-

${ }^{1}$ Cf. Mill, "An Examination of Sir William Hamilton's Philosophy," 4th edition, p. 594.

"Cf. Rashdall, "The Theory of Punishment," in International Journal of Ethics, vol. II, p. 22.

Cf. ibid., p. 22. 
jury the will of the damage-doer is not a source of future danger, and that to punish such an offender would be socially inefficacious. It is this matter of efficacy for future protection that is the criterion. In fact, when society believes that the involuntary or accidental harm was the result of lack of attention, it may decide to administer punishment in order that in future the attention may be mechanically excited or sustained by the fear of punishment. Society wishes greater carefulness in social intercourse, so it gives the punishment in order to develop it. It is the principle of social protection that leads society to threaten (and to inflict, in order to make its threats believed) a very severe punishment in certain kinds of negligence; for example, the negligence of a train despatcher or a railroad engineer which has caused serious injury, no matter how much or how little moral blame may be involved.

Another fact going to show that the justification of punishment is not retribution for the past, but is social necessity of prevention, is the fact that to certain classes of offences, like political and military ones, extremely grave penalties are attached. Society does not want soldiers to be guilty of insubordination or sentinels to be negligent while on duty, and so it sometimes punishes beyond all proportion to the moral blame and actual damage in the particular case.

A further argument to the same effect is that the law sometimes punishes acts which in themselves could not arouse any moral resentment, and punishes other acts with much greater severity than would correspond with the moral resentment which 
they evoke. The state is intent on securing the socially most desirable end. In order to do this it has the right to sacrifice the welfare of individuals; and it does this sometimes even in cases where no crime has been committed. If social interest and expediency are justifiable principles of social action in such cases as these, why do we seek for a different ground in the treatment of criminals? ${ }^{1}$

The impracticability of adjusting punishment to offence is also an argument against the retributive conception. On the one hand, it is impossible to obtain any accurate or satisfactory measure of the wrong done by the malefactor. How can we scale, with reference to each other, the amount of damage caused in the case of a libel, a deception, a perjury, a seduction, a breach of promise to marry, a watchman's negligence of duty? On the other hand, the amount of suffering experienced by the punished victim cannot be exactly calculated. It depends on the individual's temperament. The infamy of even the most trivial arrest and mention of it in the newspapers causes one offender more intense suffering than ten years of imprisonment cause another. Let any one sit down and attempt to write out a list of crimes with the number of months' imprisonment which they intrinsically merit as retribution, and he will soon conclude that the retributive principle of returning evil for evil and in proportionate measure is thoroughly impracticable.

There can be no real equivalence between the amount of suffering inflicted by the criminal and that which he sustains in punishment. It is im-

${ }^{2} C f$. Westermarck, op. cit., vol. I, p. 199. 
possible for society to calculate either the amount of pain which the criminal's victims have experienced or the amount of pain which the criminal undergoes in his punishment. The death penalty for murder is the only case where there is even an apparent uniformity between the two sufferings. But even here the likeness is only superficial. The amount of suffering in death depends almost wholly upon the circumstances; and the circumstances of the murdered victim and of the executed murderer are entirely different. In the case of imprisonment with hard labor as the penalty for robbery, or attempted robbery, there is obviously no equivalence between the suffering caused by the crime and the suffering caused by the punishment. So, when this theory maintains that the justice of punitive affliction consists in equality between the gravity of the crime and the severity of the punishment, it is weakened by the consideration that neither a crime nor its punishment admits of quantitative measurement. ${ }^{1}$

Society gains nothing by the principle of retribution and can lose nothing by abandoning it. Retaliation is not only useless; it works against deterrence and reformation. Society needs not that its criminals should suffer, but that it should be effectually protected and that they should be changed into constructive social forces. Instead of revenge for past damage, it requires security from future injury, which the retributive principle not only fails to achieve, but tends to defeat, by hardening the young delinquent and strengthening the

${ }^{2}$ Cf. T. H. Green, "Principles of Political Obligation," "Works," vol. II, pp. 494, 502, paragraphs 184, 190. 
purpose of the faltering. By meeting violence with violence it arouses a vindictive and retaliatory spirit. Our jails and prisons seem but to manufacture criminals, and "the worst prison sends out the worst prisoners." Thus vengeful severity operates as an incentive to further crimes. It kindles fires of resentment where they did not exist, and fans the flames of criminal mania. 


\section{CHAPTER III}

\section{PUNISHMENT FOR DETERRENCE}

\section{Explanation and Defence of Theory}

Punishment, according to the theory of deterrence, is not an end in itself, but is a means of attaining an end. It is inflicted, not because wrong has been done, but in order that wrong may not be done. The theory is based on sociology and psychology. Sociology furnishes the ultimate aim - the protection of society; psychology furnishes the means the influence of intimidation in restraining from crime. Penal practice is to be regarded as purely a means of intimidation for social preservation. In punishing the criminal, whether by fine, imprisonment, or execution, the aim is simply that of deterring him from further crime and at the same time frightening others who might be tempted to imitate him.

Plato put into the mouth of Protagoras these very reasonable words: "No one punishes those who have been guilty of injustice solely because they have committed injustice, unless indeed he punishes in a brutal and unreasonable manner. When any one makes use of his reason in inflicting punishment, he punishes, not on account of the fault that is past, for no one can bring it about that what has been done may not have been done, but on account of a fault 
to come, in order that the person punished may not again commit the fault and that his punishment may restrain from similar acts those persons who witness the punishment." 1

Beccaria expressed the purpose of punishment as follows: "The end of punishment is simply to prevent the criminal from doing further injury to society and to prevent others from committing the like offence. Such punishments, therefore, and such a mode of inflicting them, ought to be chosen as will make the strongest and most lasting impression on the minds of others with the least torment to the body of the criminal." 2

Hobbes said that "the aim of punishment is not a revenge, but terror." 3 Hume's conception of the deterrent influence of penalty was expressed thus: "All laws being founded on rewards and punishments, it is supposed as a fundamental principle, that these motives have a regular and uniform influence on the mind, and both produce the good and prevent the evil actions." " Bentham maintained that "example is the most important end of all."s

Schopenhauer's view of the principle that ought to lie at the basis of criminal law was that it is not really the man, but only the deed which is punished, in order that it may not recur. He said that the crimi-

"Plato, "Protagoras," p. 324. See also "Gorgias," p. 479; "Politicus," p. 293; "Laws," ix, 854; "Laws," xi, 934; "Laws," xii, 944.

2 Beccaria, "Traité des délits et peines," chap. XII.

" Hobbes, "Leviathan," chap. XXVIII.

"Hume, "Enquiry Concerning Human Understanding," ed. SelbyBigge, 2d edition, 1882, section VIII, part II.

"Bentham, "Principles of Morals and Legislation," p. 170. See also his "Rationale of Punishment," pp. $19 \mathrm{ff}$. 
nal is merely the subject in whom the deed is punished, in order that the law may retain its deterrent power. The measure of the penalty is determined by considerations of the magnitude of the injury to be guarded against and the strength of the inducements which impel to the forbidden action. The criminal code should be simply a register of countermotives for possible criminal deeds, each of these motives decidedly outweighing those which lead to the undesirable behavior. If the legal threats fail to accomplish their object in particular cases, the threatened chastisement must be given; otherwise the law and its penalties would be impotent in all future cases. That penal suffering ought to bear a proper proportion to the crime does not depend upon need of expiation or retribution, but rather on the fact that the pledge ought to be proportionate to the value of that for which it answers. ${ }^{1}$

The predominance of the deterrent idea over the retributive idea is well illustrated in the following story: A prisoner, condemned for horse-stealing, when asked by the judge why capital sentence should not be pronounced against him, answered, "It is hard to hang a man for only stealing a horse"; whereupon the judge replied, "Man, thou art not to be hanged only for stealing a horse, but that horses may not be stolen." 2

The deterrent operation of punishment may be sketched as follows: Punishment may affect the body of the offender, through imprisonment or exe-

${ }^{1}$ Cf. Schopenhauer, "Die Welt als Wille und Vorstellung," Bd. II, S. 685; "Ueber die Freiheit des Willens," S. 101.

${ }^{2} C f$. Kenny, op. cit., p. 27. 
cution, so as to deprive him, either temporarily or permanently, of the power to repeat the offence. It may influence his mind, counteracting his criminal habits, or even eradicating them, by the terror which it inspires, and may train him to habits of industry and a sense of duty. It may, in addition, act on the minds of others, deterring them by fear. ${ }^{1}$ "It is supposed that the sad fate of the condemned criminal will lead him to give up his unlawful career upon liberation in order to escape future discomforts; while the dread spectacle of his fate should restrain possible offenders by arousing in them fear of a like suffering." 2

Punishment's sanction lies in the fact that as a promise or threat preceding action it tends mechanically to produce it. This accomplished, its value is exhausted and its justification ended. It is simply a means of protection, and is based on belief in determinism. The idea of future pain enters as a causal motive to prevent crime. This explains why idiots are no longer punished. The practice was given up after trial showed that fear of penalty had no efficacious influence upon them. An act contrary to the social order is proof that neither the motive of respect for the interests of society nor the motive of letting reason control passion has been strong enough. Hence the judge has the function of applying punishment so as to strengthen these motives. Man is a machine that thinks, and has ideas for springs. Each thought is a force. The thought of future punishment is a force as truly as

${ }^{1}$ Cf. ibid., p. 28.

${ }^{2}$ Parsons, "Responsibility for Crime," p. 61. 
any other idea, and is per se no less fatal or less powerful. It may counteract other forces in the mind of man. Hence punishment may be threatened and used as a means of efficacious influence upon action. The fear of punishment will tend to cause a man to avoid the act with which the idea of punishment is associated." 1

The deterrent aim appears most clearly in contrast with the retributive or "retrospective" theory. When we admit that penalty is inflicted because a crime has been committed, we mean simply that this because is the occasion of punishment; we do not mean that it is the ground of punishment. The latter is to be sought in the effect; and the effect is necessarily in the future - punishment is inflicted upon the criminal in order that crime may not be committed. We cover up a well because a child has fallen into it, and in order that a similar event may not occur again. We lock our houses because houses have been entered and robbed, and in order that loss may not occur to us. If it were not for the in order that, the because would not determine us to act as we do. If there were no future, there would be absolutely no aims and no acts. ${ }^{3}$

Punishment is prospective rather than retrospective. It aims to prevent harm. This object gives the true measure for determining the amount required. This is found in the importance of the interest harmed, relatively to the system of rights of which it forms a part, and in the degree of terror

${ }^{2}$ Cf. Fouillée, op. cit., p. 41, and Guysu, "Is morale anglaise contermporsine," pp. 212, 361-362.

${ }^{2}$ Cf. Psulsen, op. cil., Bd. II, S. 147 . 
which must be associated with the crime in order to protect the interest in question. The amount of punishment is measured by social necessity; and this is a changing standard. A punishment which may be needed at an earlier stage of social progress - for example, the death penalty for theft - becomes unjust, because no longer a social necessity, at a later stage.

Society, in dealing with a damage-doer, aims principally at protecting itself from further damage. It seeks protection from this offender and from wouldbe offenders. It regards the infliction of pain on the malefactor and the threat of similar pain for future malefactors as the most rational and efficacious means of warding off harm, and as thereby justifiable. The sole justification for afflictive treatment of the criminal is its deterrent effect. If punishment intimidated nobody, it would sink from the plane of rational action to the level of senseless cruelty. The social scientist rejects absolutely the retaliatory aspect of punishment. The only scientific ground for inflicting pain is protection. This practical aim, under one form or another, already shapes penal practice in a slight degree. The sooner it comes to prevail and to be unreservedly adopted by legal writers and penologists, the better. "A scientific penology will graduate punishments primarily according to the harmfulness of the offence to society, and secondarily, according to the attractiveness of the ofjence to the criminal. . . . The social mission of the law is not to make evil-doers smart, but to deter from evil doing. Whatever the cave-men may say, not the ' $C f$. Seth, op. cit., p. 305. 
crimes punished, but the crimes prevented should measure the worth of the law; and such a standard, were the statistics forthcoming, might show our courts and jails to be ten times as useful as they appear." 1

The deterrent aim is seen clearly in those cases where criminal law and punishment assume a severity far beyond the moral gravity of the offence. For instance, ${ }^{2}$ the punishment of death has been inflicted on the man who dressed himself like a woman or the woman who dressed herself like a man; on persons who carried off or changed the boundaries placed in the fields by public authority; on counterfeiters, thieves, pick-pockets, horse-stealers, cattlestealers, sheep-stealers, forgers; and on many other persons guilty of crimes no more serious than these mentioned. The laws given in the books of Exodus and Leviticus impose the punishment of death for such offences as breach of the Lord's day, going to wizards, eating the fat of a beast of sacrifice, eating blood, approaching unto a woman "as long as she is put apart for her uncleanness," and various kinds of sexual outrages. In England, in 1837, the death penalty was removed from about two hundred crimes. The severity of punishment had evidently been regarded as beneficial to society. The aim was that of deterrence.

The deterrent purpose appears clearly in the practice of punishing criminals in public. It was once the custom in England for offenders to be whipped

${ }^{1}$ Ross, op. cit., pp. 110, 124.

${ }^{2}$ For the examples cited, as well as for many others, see Westermarck, op. cit., vol. I, pp. 186-191. 
in the streets, and for murderers, after execution, to be left hanging for days and weeks as an example to deter others from capital offences; and in order that the bodies might last longer, they were saturated with tar. During the Middle Ages, mutilation was a popular punishment, because such a striking example of justice was considered to have great deterrent effects. ${ }^{1}$

Society punishes a good many harmful acts which were unintentional. No bad motive lay behind them. They were produced involuntarily, from lack of forethought. Society inflicts suffering, not for the sake of the past, but out of regard for the future. It desires attention on the part of its members in social intercourse. Carefulness has to be exercised lest the rights of others be damaged. Attention may be mechanically excited and sustained by the fear of punishment; so it is on this account that penalty is threatened in case of carelessness. Punishment is to develop attention and thus to protect society.

Similar considerations dictate the severity with which "criminal negligence" is in some cases punished. The severity is justified by the principle that crime should be punished according to the importance of the interest which it harms and to the degree of terror which needs to be associated with the crime in order to protect the interest. The carelessness of a locomotive engineer who overlooks a signal and causes a fatal accident may contain no more moral depravity than is contained in such negligence as all of us are constantly guilty of. Mul-

${ }^{1}$ Cf. Westermarck, op. cit., vol. I, p. 192. 
titudes of actions and omissions involving a more depraved state of mind are not punished at all. Yet the engineer would be pronounced guilty of manslaughter and would be sentenced to penal servitude. The justification is to be found simply in the effect of the negligence in different cases upon the rights of others. In the case supposed, the most important of all rights, the right to life on the part of railway passengers, depends on the watchfulness of the engineer. Failure in vigilance needs to have sufficient terror associated with it in the mind of other engineers to prevent its recurrence. The punishment is just, however generally virtuous the victim of it is, because it is necessary for the security of interests, the protection of which is necessary to social well-being. ${ }^{1}$ Similarly, in times of war, a sentinel found negligent of duty is most severely punished, even though no actual harm has resulted. Society cannot afford that sentinels shall be negligent. The punishment aims to prevent any recurrence of the crime.

\section{Arguments against the Theory}

IF the sole or principal object of punishment is deterrence, why should not the law deliver its heaviest threats where the strongest motive is needed to restrain? To keep a man from committing a crime under great temptation or in a fit of passion a very grave penalty needs to be threatened; whereas to deter from killing one's father does not require the threat of as severe punishment as other kinds of murder, because filial affection operates to the same

${ }^{1}$ Cf. Green, op. cit., vol. II, paragraph 198. 
effect as the menaced consequences. The principle of deterrence is this: The punishment should be neither more nor less severe than is necessary for protection from crime. But if this rule were really acted upon, the penalties for some minor offences would certainly have to be made much heavier than they are at present; those for some serious crimes, much lighter. In fact, it is more difficult to deter men from petty crimes than from grave ones; - then should penalties be severer for petty than for grave crimes? For example, there is no class of offenders more difficult to restrain from repeating their offences than habitual drunkards and vagrants, whereas the chances are slight that a man who killed another in a fit of passionate jealousy or suspicion of adultery would ever repeat the offence. According to the principle that the object of punishment is deterrence from crime, should not the law let off the murderer with a light penalty and imprison the petty offender for the whole of his life? ${ }^{1}$

If deterrence were the object, then where it was impossible punishment would have to be renounced. The absolutely hardened and incorrigible offender would have to go scot-free instead of being the most severely punished of all. At present, judges consider a weakened capacity of self-control to be a mitigating circumstance - as where a sunstroke has left a man with a will-power so feeble that he pursues any passing pleasure with little regard for consequences. According to the principle of deterrence, however, insanity, when not of such a form as to destroy responsibility, ought to aggravate the pun-

${ }^{2} C f$. Westermarck, op. cit., vol. I, pp. 82-83, 200. 
ishment; for the weaker a man's will, the more sternly does it need to be braced by the fear of penalty. ${ }^{1}$

In agreement with the principle of deterrence it might be argued that a theft committed by a starving man ought to be punished very severely in order to have the strong inducement to theft offset by a strong inducement to honesty. Instead of the hunger of the thief being a reason for lightening his punishment, it is a ground for increasing it, so that the great temptation to steal when in agonizing hunger may be neutralized by the great terror associated with the commission of theft under such conditions. Now, the fact that "extenuating circumstances" are taken into account and modify punishment shows that this is not solely for deterrent purposes, but represents the moral disapproval of the community. "Extenuating circumstances" are held to lessen moral guilt and penal desert.

If the sole object were deterrence, then punishment should be much harsher in the case of first and young offenders, with whom it is most likely to be efficacious, than with old and hardened criminals, with whom no amount of it could be effective.

Penalty administered on the principle of deterrence would be completely disarmed in the case of the penitent offender. Repentance would have to be followed by liberation. There could be no crime for which it would not secure immunity from punishment.

The principle of deterrence would justify a practice of inflicting on an unsuccessful attempt to commit

$$
{ }^{1} C f \text {. Kenny, op. cit., pp. 30, } 53 .
$$


crime as grave a punishment as on the actual crime. The would-be criminal who has failed to accomplish his object simply on account of mere chance failure of the pistol to fire, or age and weakness of the poison - is just as dangerous to society as the criminal who has been more successful. And just as severe a penalty is needed to deter from attempting murder as to deter from murder. Yet society would not consent to the execution of the man whose pistol had missed fire, while it would demand the execution of the same man if his brother's blood cried from the ground for vengeance. This fact goes to show that punishment is justified not by deterrence but by moral justice.

It is a generally accepted principle that punishment must be graduated according to the degree of the misconduct. A petty offence must not be visited with grievous affliction; a grave crime must not be met with trivial recompense. This principle is entirely independent of the efficacy of the punishment in deterrent effects. If two similar thieves were brought before a judge, and the one were sentenced to five years at hard labor while the other escaped with a mere reprimand, the people's moral sense would feel outraged at such a miscarriage of justice.

If the aim were deterrence, every punishment would have to be made as public as possible. But this is directly contrary to the movement of historical development. In earlier times, the maximum of publicity was sought; nowadays, the minimum. Punishments tend more and more to be kept from the public. It is the desire of the makers and 
executors of the laws to admit the public as little as possible into the knowledge of penal sufferings. This tendency militates against the notion that the object of legal chastisement is deterrence. How can punishment be expected to have deterrent effects on possible criminals when knowledge of it is kept from them?

The acts which the law forbids and penalizes are acts which are condemned by the general moral consciousness as wrong. And it is their wrongness which has always and in all places been regarded as the justification of their being punished. Penal treatment cannot mean simply that the person subjected to it suffers for the sake of society. It implies necessarily moral opprobrium. Unless this moral opprobrium attaches to the pain inflicted, it cannot be called punishment.

The theory of deterrence refers, and pretends to refer, only to outward conduct. It has no concern with the internal moral nature from which that behavior springs. When punitive awards are declared to be just in so far as they accomplish good deterrent effects, justice is reduced to the level of simple social expediency. It is made to depend on its practical value to society. This implies that if some more economical means of deterring from crime is discovered, then punishment will be no longer justifiable. All this amounts to saying that the rightness of punishment is not its ethical justice.

A distinction between the legal and the moral should be recognized. The legal aim of punishment may be deterrence or prevention; but the 
moral aim must be justice. Punishment always has been, and always will be, the result of the moral sense of justice. It is not because certain acts have been penalized by the state that they have been considered morally wrong; but it is because they have been regarded as morally wrong that they have been corrected by the state. The sense of justice is not the result of punishment, but punishment is the result of the sense of justice. Or, as the same truth was tersely expressed in the epigram of Victor Cousin, "Punishment is not just because it deters, but it deters because it is felt to be just." 1

Another fact indicating that the correct principle is not deterrence is the generally accepted view that punishment must not outrun the moral approval of the community and must not be so harsh as to outrage the moral sentiment of justice. Society will not tolerate the chastisement of something which it does not condemn; and it will not permit greater severity than that dictated by the degree of its condemnation. "Experience shows that the fate of all disproportionately severe laws which make too liberal use of punishment as a deterrent is that they come to be little followed in practice and are finally annulled. As Gibbon says, "whenever an offence inspires less horror than the punishment awarded to it, the rigor of penal law is obliged to give way to the common feelings of mankind." " 2 Thus, taken in the large, punitive affliction faithfully reflects the emotion of social resentment for acts already committed. It has strict reference to the sense of justice, and can-

"Cousin, preface to the "Gorgias" of Plato.

'Westermarck, op. cit., vol. I, p. 199. 
not be explained mainly from considerations of determent.

Deterrence is shown to be not the end of punishment by the refusal of English and American law to treat necessity as an excuse for homicide. Penalty is inflicted even where the fear of it could not suffice to deter. "In the extreme case of a starving crew of shipwrecked men, who slew and fed on one of their number deemed least likely to survive, and in the ... case where the accused lightened a sinking boat by throwing overboard a superfluous passenger to save himself and the rest," punishment was given nevertheless. ${ }^{1}$

The passionate emotion into which an entire community is thrown upon the commission of some heinous crime, the eagerness with which all the people join in the hunt for the perpetrator, the satisfaction that is felt by all upon his apprehension, the demand that he be summarily punished, all have their cause, not in a vague desire for social protection, but in the specific demand that justice be done, thus showing that the aim is not deterrence but satisfaction of the sense of justice.

If punishment be justified by its efficacy in deterring from crime and thus promoting the general welfare, why sacrifice only the offender? His children also are sources of danger to society. Our knowledge of the working of the laws of heredity makes us quite sure that the offspring of certain parents will be a burden and harm, and that the best thing we could do for the protection of society would be to isolate or deport them. So far as the

${ }^{1} C f$. Kenny, op. cit., p. 31. 
principle of deterrence is concerned, the innocence of the children can count for nothing. Imprisonment or deportation would be perfectly right. ${ }^{1}$

The principle of deterrence has no intrinsic connection with the infliction of suffering. It involves no inherent desire to cause pain to the offender. The administrator of justice, according to this theory, could feel no more sympathy with the person who suffered innocently, yet benefited society thereby, than with the person who suffered on account of his badness for the benefit of society.

The conclusions from the principle of deterrence would lead us to the position that punishment should be measured, not by the gravity of the crime, but by the likelihood of a repetition. The son who murdered his irate father, the husband who killed his adulterous wife, the trustee who squandered the funds intrusted to him and then relinquished his position and all opportunity of doing so again, might all be left in freedom, while the tramp and the pickpocket, who the judge knows will certainly repeat their offences at the first chance, should be imprisoned for life. Thus, the deterrent theory is refuted by the considerations that punishment is given even though there is no danger of repetition of the offence, and that punishment is not given in many instances where society is endangered. Indeed, if the aim of punishment were to restrain all who, through hereditary inclination to crime, habitual carelessness and recklessness, drunkenness, mental aberration, etc., could presumably be regarded as dangerous, then the entire population would have ${ }^{1} C f$. Westermarck, op. cit., vol. I, p. 82. 
to be divided into two groups - the one to sit behind bars and locks, the other to keep guard and watch. ${ }^{1}$

How could the aim of punishment be deterrence when it is so evident to any careful observer that punishment has so little deterrent effect? The practice of meeting force with force and violence with violence can only arouse the spirit of retaliation and vindictiveness. Severity, instead of proving a deterrent, operates rather as an incentive to further crime. It kindles and fans the fires of resentment. Drähms says, "The most enlightened penologists and jurists confess to the entire inadequacy of punishment as either a preventive or repressive measure. ... The traditional belief that punishment is a cure for wrong-doing is based upon a fallacious generalization that has not the verification of experience back of it." 2 Brockway's experience at Elmira furnished ample opportunity for observation and study of the principle of deterrence. He said: "The uncertainties and delays of punishment in the actual practice of the courts, the solace to the criminal of his notoriety, and the familiarity of the public with crimes and penalties, must considerably diminish the deterrent effect." 3

Henderson's testimony is similar. "This power of punishment to intimidate has very narrow limits. It is well known by students of the subject that the danger of being caught and of serving time acts as a stimulant to many adventurous criminals, and since

${ }^{1} C f$. Wundt, op. cit., Bd. II, S. 146-147.

- Drähms, "The Criminal," pp. 340-341.

"Brockway, in "The Reformatory System in the United States," edited by S. J. Barrows, p. 20. 
most of them are essentially gamblers, they regard the chance of being detected and convicted among the risks of the game which they are playing. The vital connection between gambling and crime is well established, and it has great significance in estimating the real value of the deterrent agencies of society. The criminal is also characterized by narrow views of life, by want of foresight, and certain groups of them, by slavery to passion. These characteristics explain the small deterrent influence of our penal machinery upon the criminal class. At any rate, most of the sentences are short and have no deterrent effect upon a vast number of very degraded and even dangerous men." 1

The inefficacy of punishment as a deterrent has been conclusively proved by the work of criminal anthropologists and sociologists. If the criminal population were composed of ordinary men, afflictive penalties might constitute an effective check on the tendency to crime. But it is not composed of ordinary men. The great army of wrongdoers who are passing in a ceaseless stream through our prisons, penitentiaries, and penal servitude establishments is not made up of the same elements as the lawabiding sections of the community. Vast numbers of the criminal population live under abnormal biological and social conditions, which act upon the offender either independently or, as is more often the case, in combination, and make him what he is. Penal laws are framed and administered on the hypothesis that the criminal lives under the same set

'Henderson, "Ethical Problems of Prison Science," in International Journal of Ethics, April, 1910, vol. XX, p. 284. 
of conditions as an ordinary man, that all offenders are alike and are affected in exactly the same way and to the same extent by penal discipline. The result is a continuous growth of the recidivist class; a failure of penal law and penal administration to protect society; a steady increase of expenditure in connection with the repression of crime. ${ }^{1}$

Ferri gives a very explicit denial of the deterrent value of punishment. "The penalties hitherto regarded, save for a few platonic declarations, as the best remedies for crime, are less effectual than they are supposed to be. For crimes and offences increase and diminish by a combination of other causes, which are far from being identical with the punishments lightly written out by legislators and awarded by judges. History affords us various impressive examples. .... Even apart from statistics we can satisfy ourselves that crimes and punishments belong to two different spheres; but when statistics support the teaching of history, no doubt can remain as to the very slight (I had almost said the absence of any) deterrent effect of punishments upon crime." ${ }^{2}$

The theory of deterrence displays an ignorance of the character of the born criminal. This offender lacks foresight, and will not usually measure the gains of crime with the ills of punishment in order to determine whether it is worth while to commit crime. Furthermore, powerful forces in the organism of the congenital wrongdoer lead him to misdeeds regardless of whether or not he is conscious

${ }^{1}$ Cf. Morrison, in introduction to Lombroso's "Female Offender," pp. viii, ix, xviii.

${ }^{2}$ Ferri, "Criminal Sociology," pp. 82, 84. 
of the consequences, and minimize considerably the deterrent influence of punishment on him. Upon other classes of criminals, intimidation by punishment is also slight. An evil that is so uncertain and so distant does not often serve to prevent a vicious man from indulging his propensities, especially if his motives are violent and sudden. The criminal of passion is the victim of an "explosion" that is subversive of reason. The professional criminal calculates the possibilities of escape, and deliberately plans to run the risk of having to endure the penalty for his crime. These facts indicate how slight is the deterrent value of punishment.

If society's aim in punishing its criminals had been that of deterrence, it would long ago have discovered that punishment cannot accomplish that aim and ought to be abandoned or, at any rate, profoundly modified. Such facts as have just been presented have been known for a long time, but they have caused very little change in penal procedure.

Nearly all the champions of the deterrent theory make the good effects apply to other persons besides the culprit himself. They maintain that punitive suffering should be administered in order to restrain those who might be inclined to commit crime. They believe that the chastisement of one wrongdoer acts as a deterrent upon would-be criminals. Now, before discussing the injustice of punishing one person in order to influence others, it is worth while to call attention to the fact that the belief that correction of one offender is efficacious in checking others has very slight foundation in practical experience. As has just been shown, penal affliction 
does not even restrain the victim himself. The steady growth of the recidivist class shows that there is something fundamentally ineffective in the system of punishment. Almost two-thirds of our prison population is composed of recidivists. Many of these have been subjected to penalty a great number of times, but without avail toward stopping their crimes. Now, if punishment has such slight deterrent influence on the persons experiencing it, is it not absurd to think that it will have great efficacy on those who are not at all affected by it? It is more reasonable to suppose that if it has so little preventive effect on the culprit undergoing the suffering it will have practically none on those who are not at all touched by it.

Besides this matter of practical inefficacy, it may be further argued that it is essentially unjust to punish one person for the sake of influencing the behavior of others. The criminal has certain rights which cannot be disregarded. His personality and his future must be taken into account. He cannot be used merely as a means. Society is itself guilty of a crime if it punishes any one who does not deserve it on his own account, that is, solely out of regard for his own wrong-doing. And it is also criminal if it adds one whit to his suffering beyond the requirements of his own just desert, whether it be added for the sake of good effect on others or for any other reason.

This principle of punishment for restraining influence on possible criminals often leads to injustice and gross brutality. A crime has been committed - let us say that a negro has raped a white 
woman - people think that a negro must be lynched in order to prevent other outrages. If the guilty one cannot be found, there is grave danger that some other one will be sacrificed for the sake of the "good deterrent effects." Seignobos, in his "Political History of Europe Since 1814," relates an incident in French history which shows the pernicious extent to which the principle of deterrence may be carried. "After the discovery of the Republican plot of 1853 , and three attempts to assassinate the emperor, the administration obtained the passage of the general security act (1858), which 'gave government the power to detain, exile, or transport, without trial, any person previously condemned for political offences, and to imprison or exile any person so condemned in the future.' Espinasse, a general, well-known for his share in the coup d'etat, was appointed minister of the interior to apply this law. He sent an order to each prefect to arrest a certain number of persons, using his own choice in the selection. According to Blanchard this number varied from 20 to 41 ; it was 'proportioned to the general spirit of the department.' Each prefect interpreted the order in his own way - some limiting themselves to men condemned at the time of the Republic, others taking those who seemed to them dangerous, chiefly working-men, lawyers, and doctors. The object was simply to intimidate the people." 1

If punishment were made just by its usefulness to society in deterring from crime, the punishment of innocent persons would often be justified. Guyau regarded this argument as impotent. He quoted ${ }^{1}$ Seignobos, "Political History of Europe Since 1814," p. 176. 
Victor Cousin's statement, "Punishment in striking the innocent might produce as much or more terror and be as preventive," and then proceeded to criticise it adversely. He said, "The objection is infantile. Take an example. Society wishes to prevent incendiary fires - to do this it arrests and punishes people who have never been guilty of incendiarism - how could such a course exercise deterrent influence? For punishment to prevent crime, it must punish crime and not its opposite. It is absurd to say, We wish to frighten the guilty, let us punish the innocent." 1 Did not Guyau miss the point? His argument concerns the deterrent utility of the practice of punishing the innocent; it does not apply to the moral justification of such a course provided it were useful. It has force against the efficacy of the practice, not against the justice of the principle. But by hypothesis the punishment of the innocent is regarded as efficacious. Then, it is claimed, the principle would justify such a procedure. The courts would be justified in inflicting penal suffering upon an innocent person provided he was generally regarded as guilty, and his punishment would exercise good deterrent effects upon would-be criminals.

Acceptance of the theory that the criminal is caused to undergo pain solely for the sake of the general good leads logically and inevitably to acceptance of the principle that any one whosoever may be made to suffer without his consent, and indeed against his will, for the sake of more important or comprehensive interests; that, for instance, the death of one man may be justly demanded where it is be'Guyau, op. cit., p. 362. 
yond question the only possible means of saving the lives of many. In order to test their students and find out how many of those who professed to find in deterrence the rationale of punishment really accepted the principle in its purity, Sharp and Otto submitted to them the following example, ${ }^{1}$ which is reproduced here to test the reader's reaction on the same problem. "Long ago, when Green Bay [Wisconsin], was a little community of two or three hundred people, situated in the midst of vast forests, an Indian chief, accompanied by a formidable band of warriors, one day suddenly made his appearance before the stockade and demanded the surrender of a certain one of its citizens. This citizen, the chief believed, on what he regarded as the best of evidence, had, a few days before this, killed a member of his tribe. The murderer, he accordingly declared, must be turned over to him for punishment. The citizens, however, pointed out to the chief, - what was the truth, - that the man in question had been busy with a piece of work for the past two weeks, and had not left the settlement in all that time, so that it was impossible he should be the guilty person. The chief, however, believed they were all lying and threatened that he would attack the town and kill every soul in it if they did not comply with his demand inside of twenty-four hours. The whites knew that the chief was a man of his word; that, accordingly, if he promised to withdraw and molest them no further upon the surrender

${ }^{1}$ Sharp and Otto, "A Study of the Popular Attitude Towards Retributive Punishment," in International Journal of Ethics, April, 1910, vol. XX, pp. 352-353. 
of their fellow-citizen, he would do so; that, in like manner, if he threatened an attack in case of their refusal, he would certainly carry out his threat. In deliberating over the matter, they concluded that the chances were good that they could hold out until help could be obtained from a distance. But they recognized at the same time that, in the event of an attack, a large loss of life was inevitable, amounting, perhaps, to fifty or more of their number. On the other hand, they also recognized that to give up their fellow-citizen meant for him certain death. The man in question was unwilling to surrender himself. What ought they to do? . . . It is to be understood that the surrender of the citizen would not be imprudent as creating a dangerous precedent, or exhibiting a real or apparent weakness of which advantage might be taken. . . The conditions, then, being as described, how many of our champions of deterrence will justify the sacrifice of the one for the many in the case before us?"

The theory of deterrence rests on the view that punishment exists, not on account of the actual criminals, but because of possible wrongdoers. The murderer is executed and the thief imprisoned in order to set up an example. Now, aside from the fact that this result, as statistics teach, is not usually accomplished, since with the cruelty and publicity of executions and punishments the number and gravity of crimes increase rather than diminish, the object is in and of itself irrational. It is both unjust and unreasonable to administer penalty in order to produce an effect, not on the victim, but on some third person. The basis of such an absurd view of 
punishment's object lies in confusing the general existence of the legal and penal order with a particular instance of its application. The general legislative and punitive order exists for the good of society, or because it is the will of the individuals that it should be. Each individual wills that his will be subordinate to the general or collective will; therefore the legal and penal order exists. It is a confusion to think that it exists in order to frighten any would-be damage-doer. If he does not will to serve the general interest, he cannot be frightened into willing it. The fear of punishment will not be able to restrain him from crime. The criminal, like any other man, believes what he hopes, and so reckons on escaping detection and punishment. ${ }^{1}$

${ }^{2}$ Cf. Wundt, "Ethik," Bd. II, S. 151-152. 


\section{CHAPTER IV}

\section{PUNISHMENT FOR REFORMATION}

\section{Explanation and Defence of Theory}

According to this view, the supreme aim of punishment is the reformation of criminals. Penalty is designed to effect the betterment and cure of those who come under its operation. Society is not restricted to justice; it should engage also in beneficence. It is to administer legal correction out of benevolent regard for the good of the criminial himself. Justice is not the only word nor the final word. Fraternity or universal brotherhood is its completion. Love is the complement of justice.

It is worthy of remark that in the conception of punishment held by Plato and Aristotle the element of retribution was almost entirely absent. They regarded the proper object of punitive treatment as either deterrence or reformation, and assigned the greater importance to the latter. They thought of penal affliction as a moral medicine to purge the soul of wickedness. And ever since the time of Plato and Aristotle the doctrine of reformation has been emphasized by moralists who could not rest content with the idea that the state, in punishing, was concerned merely with the infliction of so much suffering, and had no responsibility in regard to the moral effect of the punishment on the criminal. 
Are we right in hating the criminal? He is born into crime, predetermined and necessitated to wrong. $\mathrm{He}$ is already a prisoner-held in chains and weights. If these were removed, he would rise to higher things and be lovable as any human being is lovable. If we could descend into the heart of the person seeming to merit hatred we should discover good human possibilities held in fetters. Our hatred would change to pity, because, instead of finding there a will or character that was bad from freedom of choice, we should behold one enslaved to evil and yet capable and desirous of the higher life. Must we not love such? Is it not such that merit most especially our pity and love?

Crime is the result of the operation of the laws of heredity and environment. The criminal is born a criminal or is made one. He is diseased, and needs to be cured, not punished. If crime is a pathological phenomenon, a form of insanity, an inherited or acquired degeneracy, then the proper treatment of the criminal is that which seeks his cure rather than his punishment. Hospitals, asylums, and reformatories must take the place of prisons. The hard, blind desire for justice and the unrelenting and unreasonable spirit of vindictiveness must yield to a gentler and wiser humanity. Society is now so securely organized that it can afford to be not merely just but generous as well.' $\quad$ The human individual, even though a criminal, must not be treated as a thing - to be destroyed without consideration of personality. He must be convinced of the righteousness of his punishment; his slumbering conscience ${ }^{1} C f$. Seth, op. cit., pp. 314-315. 
must be awakened. If punishment does not aim at this, it is not moral. To be moral, it must not simply restrain the wrongdoer, by external force, from a particular act on a particular occasion, but must attempt to extirpate his depraved instincts and to convert his evil nature. It is not even truly deterrent unless it is reformative, unless it remoulds the character of the criminal, unless it causes him to see the wrongness of his ways, to repent, and to lead a better life.

Punishment is thus not designed to be an evil. The criminal's estimation of it as an evil is due to the fact that he does not recognize it in its real character of a blessing. His ignorance of his true interest is like that of the sick man when he detests the medicine, or that of the school-boy when he complains at being forced to go to school.

The philosophy on which the principle of reformation rests may be sketched as follows. Punishment is shown by experience to be one of the most effectual ways - and in some cases the only effectual way - of producing the amendment of offenders. It does not simply induce them to abstain from wrongful acts for fear of the consequences, but actually makes them better. There is a higher self, as well as a lower self, in every person; and if the lower self is kept down by the terror of punishment, the higher self is able to assert itself. The contention that mere pain cannot produce moral effects is seen to be absurd when recognized to involve the assertion that no external conditions have any moral effect upon character. It is a matter of common experience that great moral changes in men's char- 
acters are often brought about by misfortune, poverty, calamity, bereavement, disgrace. The result is sometimes direct, sometimes indirect, through the awakening of religious emotions. In either case, however, all that the suffering does is to create a state of mind favorable to the action of higher motives and considerations, or to remove conditions unfavorable to their action. Punishment for reformation aims at an artificial creation of circumstances conducive to moral improvement, and has an advantage over ordinary misfortune in that it is seen to be the consequence of wrong-doing. ${ }^{1}$

The reforming influence of good environment must not be underrated. Every man has within him both good and evil tendencies. Many men are criminal because their surroundings have been such as to repress the development of the good tendencies and to favor the development of the evil. To transplant such natures into good environments may lead to "reformation" in their characters and habits. Of course heredity exerts a strong influence. The child of a criminal man and a woman of a low order of mental and moral development naturally partakes of the characteristics of both parents and has vicious inclinations. If he should grow up in the environment of a home presided over by a man and woman of this type, he would probably follow in the steps of the parents. On the other hand, however, if he should be lifted out of it, surroundings of culture and cleanliness, both physical and moral, would probably more than balance the evil heredity and make of the child an honest man. The reformatory

${ }^{\prime} C f$. Rashdall, op. cit., pp. 22, 27, 28. 
methods in our prisons are simply attempts on the part of the law to change the whole trend of the criminal's life by a temporary environment supplied by the state. If heredity were the major cause of the criminal's obliquity, surely prison or reformatory discipline could do little to make him a better citizen. But if criminality be an acquired rather than a natural characteristic, due more to environment than to heredity, then attempts at reformation may be efficacious. $^{1}$

E. C. Wines, in the resolution which he drew up for the International Congress on Penitentiary Discipline, held at Cincinnati in 1870, said: "The treatment of criminals by society is for the protection of society. But since such treatment is directed to the criminal rather than to the crime, its great object should be his moral regeneration. Hence the supreme aim of prison discipline is the reformation of criminals, not the infliction of vindictive suffering." 2

F. H. Wines also should be reckoned among the champions of the supremacy of the reformative aim. He regards the establishment of reformatory institutions as "the landmark which divides two civilizations or two historical epochs." 3 "Subjugation was the old idea; conversion is the new." " "The criminal law is also, when it is rational and equitable, and is administered with intelligence and humanity, designed and adapted to effect the amendment of those subjected to its afflictive penalties. The

"Cf. Thayer, "What May We Do With Our Criminals?" in The Survey, July 9, 1910, p. 567.

"Henderson, ed., "Prison Reform," p. 39.

${ }^{3}$ F. H. Wines, op. cit., p. 121.

‘ Ibid., p. 208. 
model of human government is found in the divine order, in which we are chastened for our profit." 1 "The theory of social protection is hardly broad enough to cover every case that may arise in the administration of the criminal law. It ignores too much the moral aspects of crime, and has too little analogy to the divine government, which always has in view the recovery of the prodigal son or daughter, in an unselfish spirit, as taught in the Christian religion by the sacrifice of the Son of God for the redemption of the race." 2

Brockway was one of the stanchest supporters of the principle of reformation. "The reformatory prison system," according to him, " . . . is ranged under a motto which reverses that of the classical school of penologists, its motto being 'Prevention the principle; punishment the incident.' It seeks the public protection through the reformation of criminals, and counts it of small moment whether the prisoner undergoing the reformative process is pleased or displeased thereat. It is held by the advocates of this system that all the ends sought by punishment for crimes, by all the schools, are best attained when protection by reformation constitutes the whole purpose and method of prison treatment; and that by this means there is incidentally reached the nearest possible realization of justice, the equitable adjustment of pain to sin. The real reformation demanded by this reformatory system is necessarily a rigorous experience for prisoners, so irksome that they would scarcely choose it; yet because the purpose of it is to accomplish a remedial result, it can scarcely be
${ }^{1}$ Ibid., p. 288.
${ }^{2}$ Ibid., p. 290. 
considered, either by the subject of such experiences or by the observer, as an unjust penalty." 1

Boies also speaks in the highest terms of the principle of reformation. "The substitution of the reformative treatment of criminality in the place of the pre-Christian codes of the lex talionis is a logical development of the law of redemption by conversion to righteousness, taught by the precepts and illustrated in the life of Christ. It relegates the punishment of sin, wickedness, vice, and immorality to God, to whom it belongs, who always and everywhere proclaims, by word and acts which cannot be misunderstood, 'Vengeance is mine, I will repay'; and restricts the functions of human laws to the protection of humanity from wrong and harm by the confinement of evil-doers until their disposition to crime is removed. It replaces vindictive cruelty toward criminals with humane efforts to cure the disease which causes criminality. . . . The reformation of criminals is not alone a Christian theory which cannot be fully verified in human life, but is now a positive and actual science, based upon facts and principles as well established as any human therapeutics. Indeed, the scientific observations of criminologists, and the recorded results of the experiments of the last twenty-five years, particularly those of Mr. Brockway at Elmira, have not only demonstrated the reliability of these fundamental facts and principles, but they have actually constituted the science of Penology. ... The uncontrollability of the criminal class is due to an unnatural or

'Brockway, in "The Reformatory System in the United States," edited by S. J. Barrows, p. 22. 
abnormal condition of the personal character of its members, which is properly designated a disease; just as insanity, inebriety, prostitution, idiocy, and epilepsy are diseased conditions of the human system. ... The prognosis of the disease of criminality is quite as hopeful as that of any of the serious diseases which afflict humanity. Information secured in 1899 concerning 274,763 reported cases of smallpox, typhoid, diphtheria, and croup, showed a fatality, in small-pox of 25.8 per cent., in typhoid fever of 19 per cent., and in diphtheria and croup of 22.7 per cent., during the years 1894 to 1898, inclusive, as compared with the $\mathbf{1 6 . 6}$ per cent., of failures in the reformation of criminals recorded as the actual results of the twenty-five years' practice of $\mathrm{Mr}$. Brockway at Elmira. This percentage of failures, moreover, was the result of a system of Penology which limited the time of treatment to a specific maximum of duration previously fixed by law as adapted to a single symptom, the crime, instead of more rationally committing its determination to the physician in charge. Such a system necessarily caused the discharge of many of the most difficult and obdurate cases uncured, thus reducing the possible average of recoveries. It may, then, be regarded as scientifically proved that the disease of criminality can be cured." 1

1 Boies, "Science of Penology," pp. 158-160. 


\section{Arguments against the Theory}

THE reformationist tells us that the criminal is a diseased person, needing treatment and cure, not punishment. But this analogy is an attempt to delude us by obscuring the main point at issue. Its inadequacy is disclosed by the touchstone, What is the chief concern? In the treatment of sickness, even the comparatively small amount of contagious sickness, the main object of consideration is the welfare of the sick person; but in the treatment of crime, it is the welfare of society. First of all, society must be protected and its resentment appeased.

The criminal, whether rightly regarded as "sick" or not, will not submit to treatment for "cure" and reformation. He insists that he is not a thing to be moulded according to your ideas of what change ought to be effected. He is a person with his own will, aims, and ideas. His will, his character, is his own, and is inseparable, inalienable. He will not give it up to society to have it operated on and to have part of it removed. Society is absolutely powerless over against the individual's will. It may force external behavior, but it cannot force changes in character.

Before punishment could be "morally" efficacious, before it could ameliorate the sufferer's spiritual nature, it would have to be affirmed by him as a just desert and desired as a good. It would have to be administered by himself. It would have to follow in accordance with his own internal ideal of what is right and just. Unless he regarded the inflicted suffering as merited, you might overwhelm him with 
it without any efficacious moral results. He would consider it an accidental misfortune due to a miscalculation in his reckoning and plans. It could not possibly serve to improve his character. Thus punishment is impotent over against the inner nature. The man must himself will the punishment as a "moral" medicine and must himself will the good which it is supposed to bring him. But he could not have such a will unless his character was already amended; and then the punishment would be unnecessary, unfitting, unjust. Thus the aim at reformation is completely disarmed. Penal affliction could have no moral effect on the culprit unless his character were already moral. But if his character were already moral, "reformation" would not be needed and punishment for such an end would be unjust.

The state has no concern in trying to estimate the intrinsic worth of an individual's character. The object of its consideration is not internal virtue and vice, but external acts and behavior. Its concern is with actions, not with motives; with conduct, not with character. It regards not religious sin and moral evil, but social wrong and crime.

The ordinary man, who is not accustomed to abstractions of thought, finds it difficult to make the discrimination between moral virtue and vice on the one hand and social beneficence and injury on the other hand. But this abstract distinction needs to be made in this connection in order to ascertain the object of punishment. Let us conceive abstractly a man whose character was bad but whose acts were in harmony with the needs and demands of society. 
Of course such a case is an abstraction. In reality, from an evil character there follow evil deeds. But to discover the real object in punishment we must consider these elements separately. Could society punish such a man? No. It can never punish a man because his character is morally bad and in order to make it better, but solely because his acts are socially harmful and in order to protect itself.

There are several reasons why it is difficult to realize that society has not the right to try to compel moral goodness. Men instinctively feel that vice unpunished is a monstrosity in the universe, a reproach to the ruler of the moral world; so they are inclined to help the moral governor give the proper punishment.

Furthermore, man has a natural impulse to correct moral deformity just as he has a natural impulse to correct physical deformity. Moral ugliness excites his repulsion as much as, or even more than, physical ugliness; and he instinctively turns away from it or tries to remedy it. He cannot rest indifferent and inactive in the presence of the incorrect, the inappropriate, the wrong, the bad. He wants to do something to set the matter right. He does not realize that there are some things which he would better not touch. Those who first found in excavations in Italy and Greece a Venus with an arm or a leg missing experienced this natural impulse to repair the damage and attempted to supply what was lacking. To-day, more timid, we leave these works of art superbly mutilated - we prefer to let our impulses suffer rather than profane and desecrate. Conditions are the same when we find ourselves in 
the presence of something morally defective. There is a mighty impulse to try to correct it. But how can immorality be remedied from the outside? Man lays hold of punishment, an instrument ready-made and at hand. But the endeavor is futile. Only the original makers of those marble statues could repair them; and only the original possessors of these individual wills can reform them. We must turn our expectations toward the future. Instead of trying to repair the irreparable, let us try to make our works that are to follow us as good and beautiful as possible. ${ }^{1}$

We have been looking at the matter with particular regard to the person to be reformed. Let us now look at it a moment with special reference to the reformers. What right have the persons administering the punishment to regard themselves as properly constituted to judge of moral good and evil and to attempt to make over the bad? It would be interesting to consider this question first in connection with Mill's philosophy. Mill was the great champion of the supremacy of the doctrine of social utility; so it is surprising to find him professing to be an adherent of the doctrine of punishment for reformation. He said: "There are two ends which, on the Necessitarian theory, are sufficient to justify punishment: the benefit of the offender himself, and the protection of others. The first justifies it, because to benefit a person cannot be to do him an injury. To punish him for his own good, provided the inflictor has any proper title to constitute himself a judge, is no more unjust than to administer medicine.

${ }^{1} C f$. Guyau, op. cit., pp. 201, 202. 
As far, indeed, as respects the criminal himself, the theory of punishment is, that by counterbalancing the influence of present temptations, or acquired bad habits, it restores the mind to that normal preponderance of the love of right, which many moralists and theologians consider to constitute the true definition of our freedom." I If what makes punishment just is the profit which the punished person himself derives from it, would not this justify often the acts of the offender himself? It may well be that the suffering which the criminal causes his victims may issue in good to them. Adversity is often the cause of moral benefit; hence, the criminal in plunging his victims into adversity may be leading them to a spiritual good. If so, according to this principle that the infliction of suffering is justified by the moral profit which the afflicted person derives from it, the criminal must be declared free from guilt or blame. ${ }^{2}$

When the criminal is told that suffering is to be inflicted on him for his good, he may revolt, he may see fit to dispute the widsom of the infliction, and may regard it as unjust. He may rebel against such a sanction even though forced to submit to it. Mill said that to punish a man for his own good is no more unjust than to administer medicine. Now, what is this supposed good, this pretended benefit, which the punished person is to derive from his punishment of, say, ten years in prison? According to Mill, "by counterbalancing the influence of present temptations, or acquired bad habits, punishment re-

${ }^{1}$ Mill, op. cit., p. 592.

${ }^{2}$ Cf. Guyau, "La morale anglaise contemporaine," p. 358. 
stores the mind to that normal preponderance of the love of right, which many moralists and theologians consider to constitute the true definition of our freedom." The profit which the criminal may expect, then, is the "normal preponderance of the love of right." Who can guarantee that "preponderance of the love of right" is something normal? And what is meant by "love of right"? What is the right? According to Utilitarianism, it is the useful. And what is the useful? It is that which produces pleasure. And what is pleasure? According to Utilitarianism, each man can know and can desire, in reality, only his own. Then why punish the criminal? He loves his own pleasure. You love yours. Where is there any difference? Plato might pronounce the criminal "sick," in comparison with the ideal man, the pattern of perfect goodness; but the Utilitarian cannot declare him "sick" other than as the Utilitarian himself is sick and as all other men are sick; that is to say, all are unable to will the least bit of real disinterestedness. Of this malady, the Utilitarian cannot hope to cure the culprit, or any one else, either by punishment or by any other means. The Utilitarian cannot talk to the offender about "freedom." He recognizes that the wrongdoer, like all other men, is a slave to motives, impulses, desires, interests, and that he seeks, and can seek, simply his own good. Now no one can be bad solely in and by himself. He can be bad only in relation to some one else. Therefore it is impossible to legitimize a sanction which considers merely the individual himself. You must renounce punishment if you are to administer it solely for the cul- 
prit's own good. Just because he has caused you suffering, you cannot declare him sick and in need of remedial treatment with suffering. He has indeed caused harm to you. But do not pretend that you are going to treat him with medicine for recovery from a malady. Deal with him as violently as you will, but do not make a pretext of his moral health, and do not try to persuade him that the sheriff or executioner is a physician. If the criminal asks, "Why do you put me to death,?" do not tell him the lie, "For your own good." The criminal's interest is not, and never will be, punishment; and punishment has not for its object, and never will have for its object, the good of the criminal. ${ }^{1}$

No one who approves of capital punishment can legitimately profess to be an adherent of the principle of reformation. If the supreme aim of punitive treatment is the amendment of the person punished, then that treatment cannot go to such an extreme as to cut off forever all chance of amendment. This fact seems so clear that it comes as a great surprise to find Alexander maintaining that the death penalty is administered to make the victim better. He says: "In some cases the wrongdoer's mind is so perverted that only loss of his life (at least in the judgment of society) will suffice. Here, too, paradoxical as it may seem, though perhaps the chief object of our punishment is the indirect one of bettering others, we punish with death in order to make him a good man and to bring him within the ideal of society. It is true that we give him no chance of showing his reformation by a further usefulness, but

${ }^{1} C f$. Guysu, op. cit., pp. 358-361. 
the penalty of death is thought necessary to bring home to him the enormity of his guilt." 1 This notion that even the death penalty is administered in order to reform the culprit is almost the height of absurdity. It shows the extreme lengths to which enthusiasm may carry one. There is a real dilemma here. If capital punishment is retained, the principle of reformation must be rejected; if the principle of reformation is accepted, capital punishment must be abandoned. The attempt to reconcile the two is futile and absurd.

Penal affliction does not cause the victim to respect it and to derive from it a moral benefit. On the contrary, it simply leads him to fear it, and to exert himself to elude it. Its efficacy can never be anything more than external. So penalty cannot be regarded as the instrument of morality; it simply causes one to fear and avoid it, but not the action to which it is attached.

If the aim of punishment be reformation, then the degrce of amelioration that is accomplished in the process is made the basis of the judgment as to how long the convict shall be kept imprisoned, or when he shall be set at liberty. That not even the keenest judge of human nature in the world could tell with any measure of probability whether or not the prisoner's decision made under the conditions of prison life would be really kept under conditions of freedom, we need not emphasize. But it is certain that genuine repentance takes place oftener among the great criminals than among the petty ones. It frequently happens that the perpetrator of some very

${ }^{1}$ Alexander, op. cit., p. 331. 
serious crime sincerely and bitterly repents, and would never commit another if released. According to the principle of reformation, such a man would have to be set free at once. On the other hand, as is well known, there is no more obdurate and incorrigible set of offenders than petty thieves, habitual vagrants, and drunkards. Hence, the establishment of the principle of reformation would lead to the barbarous result that pistol fiends, poison mixers, and murderers would, after a short and effective imprisonment, enjoy again their freedom, while petty offenders like beggars and tramps would have to be maintained for life at the public expense. An absurd result like this is fatal to the supposition that punishment is merely a means to reformation. ${ }^{1}$

We all demand that the penalty shall not be out of proportion to the gravity of the crime committed. What ardent reformationist, even, would maintain that an offender, convicted of having violated the game-laws, unrepentant, asserting that regardless of game-laws to the contrary he proposed to continue to shoot birds at any time or season he found them damaging his trees, ought to be sentenced to hard labor in the stone quarries until reformed, while a repentant and reformed murderer might be let off with a fine of fifty dollars or a short term in jail? The generally accepted principle that punishment must not exceed the limits set by moral disapproval of the damage done argues against acceptance of the aim at reformation.

The doctrine of reformation would lead to much

${ }^{1}$ Cf. Wundt, op. cit., Bd. II, S. 150, 151; Morrison, "Crime and its Causes," pp. 202, 203. 
severer punishment in a hopeful case than in a hopeless one, regardless of whether the offence of the first had been trivial in comparison with that of the second. But we should all be shocked if a slight offender were subjected to intense suffering while a great incorrigible criminal were let off easy. The reformationist shows an inconsistency in his doctrines in the case of the incorrigible offender. $\mathrm{He}$ would no more than any one else advocate the idea that the incorrigible criminal ought not to receive any punishment whatever. But if reformation were the sole object of penal treatment, the person who could not be reformed would have to be exempt from it. If not the slightest hope of reforming the culprit could be entertained, there would be no reason for chastising him at all. Incorrigibility would excuse from punishment.

If punishment is viewed as intended for the moral amendment of the criminal, can it be proved to be the best way of improving him? Would not a gentler education accomplish better results? Punishment renders hard, insensible, vengeful, and stupid.

The reformationist would have the means of punishment accomplish moral instruction and cause the criminal to become conscious of the immorality of his life. So long as such an undertaking be a sideissue, a mere accompaniment of the main process, little objection need be raised. If the criminal accepts the chastisement as merited by him, and is reformed, this is an agreeable and satisfactory result. Society may rejoice at it, but cannot make it the chief object. When the whole conception of punishment is embraced in the idea of reformation, then punish- 
ment ceases to be an evil, and thereby loses much even of the moral effect which is hoped for from it.

The deterrent principle, as truly as the reformative, would educate the offender. It aims to punish, and through punishment to instruct, and through instruction to restrain from further crime. The emphasis, however, is on deterrence through punishment, that is, through the infliction of suffering, an evil. The reformationist would improve instead of punish. He places the emphasis on education; and through education would bring to the culprit a good. Now the advocate of the principle of deterrence not only doubts the deterrent efficacy of the principle of reformation, but regards it as a relinquishment of a fundamental part of his idea, since, if the end is instruction, punishment as means may fall away, and one half of the deterrent aim be lost. For this principle would dissuade through punishment. A restraint accomplished by means of hypnotism or through drugs, baths, and massage, would not be called punishment. Similarly, when a man is induced to forswear crime through the ministrations of a prison chaplain, through education, through a book from the prison library, he is not reformed by punishment at all. Deterrent punishment means necessarily the infliction of evil, and hopes through the infliction of this evil to prevent further crime. The reformationist would substitute in place of penal correction attendance upon school, instruction in music and gymnastics, mastery of a trade, and acceptance of religion. The advocate of the deterrent motive would also have these things, but only as an accompaniment of the punitive process, not instead 
of it. There is a fundamental difference of emphasis in the two theories, due to the essential difference in purpose. The principal aim, as conceived by the one theory, is the protection of society through punishment; while according to the other, it is the amendment and good of the person punished. Punishment, in the judgment of the one, is to be an evil; while according to the other, it is to be a good. But if prison is to be primarily an educational institution, and admission to it a good for the person admitted, it is a pity that entrance can be gained only by committing a crime.

Grave objections to the theory of reformation may be raised on the ground that trial has shown it to be barren of results. Drähms says that it is becoming constantly more apparent to all students along these lines that punishment has little reformative effect. The principle which encounters force with force meets with but slight moral responsiveness in the subject, but serves rather to arouse the latent retaliatory and vindictive spirit that contains little of regenerative power. Punishment does not reach the springs of human motives, or in any sense affect the sources of responsible conduct. ${ }^{1}$

The testimony of Ferri, concerning the present attitude of scientific criminologists toward reformation, is very explicit. "No doubt the principle that punishment ought to have a reforming effect on the criminal survives as a rudimentary organ in nearly all the schools which concern themselves with crime. But this is only a secondary principle, and as it were the indirect object of punishment; and besides, ${ }^{2}$ Cf. Drähms, op. cit., p. 340. 
the observations of anthropology, psychology, and criminal statistics have finally disposed of it, having established the fact that, under any system of punishment, with the most severe or the most indulgent methods, there are always certain types of criminals, representing a large number of individuals, in regard to whom amendment is simply impossible, or very transitory, on account of their organic and moral degeneration. Nor must we forget that, since the natural roots of crime spring not only from the individual organism, but also, in large measure, from its physical and social environment, correction of the individual is not sufficient to prevent relapse if we do not also, to the best of our ability, reform the social environment. The utility and the duty of reformation none the less survive, even for the positive school, whenever it is possible, and for certain classes of criminals; but, as a fundamental principle of a scientific theory, it has passed away."

Parsons criticizes adversely a statement from Barrows to the effect that prison systems of the future must demonstrate their value and utility through the reformation of the prisoners. "Conditions which warrant Mr. Barrows in making such a statement lead us to expect that, for many years to come, millions in state money and private funds will be expended in carrying on a well-nigh hopeless experiment which, if even moderately successful, must work untold injury upon subsequent generations. Science has shown and is showing more and more the narrowing field of reformation."

' Ferri, op. cit., pp. xviii, xix.

"Pareons, "Responsibility for Crime," p. 63. 
McKim believes that criminality rests on defective brain structure and organization, and that hence reformation of the criminal is hopeless. "Toward softening the flint-like obduracy of the moral imbecile all remedies remain unavailing. We may in some measure restrain but can never reform him. The general public has not grasped the truth, now so well established, that "moral sense," like every other mental capacity, requires a fitting basis of brainstructure, and that if this has never existed, or has been destroyed by disease, a moral sense is impossible." 1

The weakness of the reformative theory of punishment, on account of the impossibility of reforming a truly bad man, was strongly brought out by Schopenhauer at various places in his writings. He said that the aim to amend the culprit proceeds on the assumption that ignorance and distress are the principal cause of crime. Yet, however large a share these may have in many crimes, we dare not regard them as the essential cause, for innumerable persons living in the same ignorance and under absolutely similar circumstances commit no crimes. The real source of crime lies in the personal moral character, which is original and unalterable. So moral reformation is really not possible, but only deterrence from the deed through fear. In order to understand the problem in its full extent, let us recall how incredibly great is the inborn difference between man and man, in a moral and in an intellectual regard. Here nobleness and wisdom; there wickedness and stupidity. In one the goodness of the heart shines out of

'McKim, "Heredity and Human Progress," p. 21. 
the eyes, or the stamp of genius is enthroned in his countenance. The base physiognomy of another is the impression of moral worthlessness and intellectual dulness, imprinted by the hands of nature itself, unmistakable and ineradicable; he looks as if he must be ashamed of existence. But to this outward appearance the inner being really corresponds. We cannot possibly assume that such differences, which involve the whole nature of the man, and which nothing can abolish, which, further, in conflict with his circumstances, determine his course of life, are merely the work of chance and instruction. How could the untiring goodness of one man and the incorrigible and deep-rooted badness of another, the character of an Antonine, a Hadrian, a Titus, on the one side, and the character of a Caligula, a Nero, a Domitian, on the other side, have come from without, have been the work of accidental circumstances or of mere knowledge and education? Indeed, Nero had Seneca for his teacher. Rather, in the inborn nature lies the real kernel of the whole man, the seed of all his virtues and vices. The real will of a man, according to Schopenhauer, cannot be reformed.

At the same time, the correction of knowledge and the awakening of the desire to work can certainly be accomplished, and will be productive of good social results. A sensible reformatory system would not undertake to amend the heart of a man, but would attempt rather to set his head right and to show him that the aims which he inevitably seeks on account of his character could not be attained by the previous way of dishonesty except with much greater difficulty, struggle, and 
danger than by the way of honesty, labor, and thrift. Thus, in knowledge alone lies the sphere and province of all improvement and amendment. The character is unchangeable; motives work with necessity, but have to go through knowledge as a medium. This, however, is capable of innumerable degrees of the most diverse development, extension, and continual correction. To this end works all education. The development of the understanding through learning and information of every sort, is morally important, because it opens the way for motives to which, without it, the man would have remained closed. So long as he could not understand these, they were not present to his will. Thus, in similar external conditions, the action of a man can be entirely different the second time from what it was the first, if he has in the meanwhile become capable of rightly and fully comprehending these circumstances, whereby motives now affect him, to which he was earlier inaccessible. But with all this, it needs to be definitely understood and remembered, that moral influence extends no further than setting one's knowledge to rights. The endeavor to remove defects of character through preaching and moralizing, and thus to reform the real morality of a man, is just like the attempt, through external influences, to convert lead into gold, or through careful culture to cause an oak tree to bear apricots. ${ }^{1}$

The utter inability of punishment to effect the moral reformation of the persons punished was asserted also by Nietzsche, with characteristic em-

${ }^{1} C f$. Schopenhauer, "Die Welt als Wille und Vorstellung," Bd. II, S. 685-687; "Ueber die Freiheit des Willens," S. 52-54. 
phasis and irony. He said that while punishment is brimful of utilities of every sort, it need not be expected to accomplish reformation. When punishment is intended to awaken the feeling of guilt, to become an instrument for effecting that reaction of soul which is called "guilty conscience," "the sting of conscience," "the gnawings of remorse," man errs therein, in ignorance of psychology. The real gnawings of conscience are extremely rare precisely among criminals and prisoners. Prisons and houses of correction are not the breeding-places in which this species of gnawing worm flourishes readily. In this opinion all earnest observers agree, even though in many cases such a judgment is arrived at unwillingly and in opposition to fond wishes. Taken in the large, punishment chills and hardens, it intensifies the feeling of alienation, it strengthens the power of resistance. If it happens to break the will and produce prostration and humiliation, the result is indeed less satisfying than the usual effect of punishment. If we think of the thousands of years in which the punishing authorities have sacrificed their victims, we may realize how the development of the feeling of guilt has been most effectually restrained. We must not underestimate the extent to which criminals, through seeing the judicial and executive procedures, have been hindered from regarding their own deeds and ways as reprehensible. For they perceive exactly the same kind of actions practised in the service of justice and called good and carried out with a good conscience - such acts as spying, deceiving, corrupting, bribing, intriguing, entrapping, the tricks and underhand dealings of 
the police in impeaching and indicting, and then the unrestrained spoliation, suppression, dishonor, disgrace, imprisonment, torture, murder - the various forms of punishment. Criminals see that these things, when done by others, are not all base or condemnable actions in themselves, but only in a certain aspect and employment.

The "guilty conscience," that most unearthly, most uncanny, and most interesting plant of our earthly vegetation, does not, according to Nietzsche, grow in such a soil. In fact, in the consciousness of the judge and punisher, there was for the longest time no trace of having to do with a "guilty" person, but only with a damage-doer, with an irresponsible piece of destiny. And he on whom the punishment, like a stroke of destiny, fell, had no "inner pain" other than what the sudden happening of some unexpected, horrifying, natural calamity, a crushing block of stone, an invincible fate, would give. For thousands of years the evil-doers who have been overtaken by punishment have felt concerning their "faults" or "transgressions": "Here is something that has unexpectedly turned out badly," but not "I ought not to have done that." They have submitted to the punishment, just as any one would submit to sickness, or misfortune, or death, with cheerful fatalism without revolt. If there happened to be any criticism of the deed, it was on the part of shrewdness. Without doubt, we must look for the real effect of punishment especially in a sharpening of cleverness, in a lengthening of memory, in a determination to go to work hereafter with greater foresight, secrecy, and distrust, in a recogni- 
tion that for many undertakings a man is simply too weak, in a kind of improvement of self-judgment. What can be attained, in general, by punishment, whether of man or animal, is the increase of fear, the sharpening of cleverness, the mastery of desire and passion. In this wise, punishment tames a man; but it does not make him "better" - the opposite is nearer the truth. ${ }^{1}$

${ }^{2} C f$. Nietzsche, "Zur Genealogie der Moral," S. 375-378. 


\section{CHAPTER V}

\section{PUNISHMENT FOR SOCIAL UTILITY}

THE preceding discussion has doubtless shown the difficulty of discovering a satisfactory purpose in punitive treatment. It may have convinced some readers that punishment can be justified by no object, but is essentially wrong. It may have led others to the conclusion that there is an element of truth in nearly every one of the theories which we have examined, even though the theory be inadequate as a statement of the main design in inflicting penalty. The latter persons would say that it is impossible to restrict punishment to one determinate aim. Its aim is complex. It is not an instrument invented to accomplish one specific purpose, but is a historical growth, which has taken into itself many diverse, almost incompatible, elements. An adequate conception of punishment must be large enough to include, and to do justice to, the various elements that have combined in it.

This notion is often maintained; and there have been one or two attempts to state the object of punishment in such a large conception that all the various elements could find a suitable place. The most important of these is the one which sets up the general formula: Punishment is administered for the sake of its social utility. Let us analyze this idea in order to see exactly what it means. And 
let us first make out as strong a case for this theory as possible, leaving for later consideration the question as to whether it needs modification in any respect.

Some other statements of this view are: Punishment is given for social defence, for social protection, for social security, for the prevention of disturbance in the economic, political, and general social order, for the realization of the social ideal, for the promotion of the general well-being, for the attainment of the greatest happiness of the greatest number.

It will be noticed that all of these relinquish the idea of concern with the individual per se. Punishment does not function as a spiritual guide for the individual. Its object is not moral or religious goodness. It is not concerned with individual personal virtue. Its notion is wholly social. It is justified on account of its utility, its necessity for the intercourse of men. It is given because essential to the preservation of organized society. If crime were not subjected to corrective discipline in a regular and orderly way by the collective authority, society would soon become disorganized. Punishment is necessary in order to enable people to carry on business peaceably, to live in security, and to enjoy life. The system of social rights and obligations can be maintained only through afflictive penalties. The criminal violates the conditions of general well-being; and in so far as he injures the common good, he forfeits his rights at the hands of the public. His punishment is justified by its social necessity. Thus society resembles a mutual insurance association, in which the members unite their strength against a common danger and insure each 
other against harm. It must eliminate what is prejudicial to its existence. The degree of the dangerousness of the criminal is the consideration by which society should be guided in determining the corrective treatment for him. Punishment, therefore, has no meaning except as intended to secure the greater and more perfect organization of society.

With the general formula of social utility in mind, let us see what measure of validity can be ascribed to each of the more specific objects which we have already considered.

In the first place, it seems that no validity can be assigned to the aim at expiation. So far as social protection is concerned, expiation may be a matter of indifference. Let injuries to the gods be the concern of the gods. No man must attempt to be the vicegerent of God on earth to avenge supposed offences against the divine. No man has the social right to force his religious views on others who think differently. Conscience is a sacred part of the individual's rightful liberty. In the case of religious belief, the claim of some individual, or of the whole of society, to exercise authority over a person who dissents is to be denounced as a violation of social right. No restrictions must be placed on conduct on the ground that such conduct is religiously wrong. The notion that it is one man's duty that another should be religious, and that the first fulfils his duty in compelling the second to be religious, was the foundation of the great persecutions. Incalculable social harm has been done by man's attempt to conduct a theocracy on earth and to punish for heresy. History abounds in mistakes of this nat- 
ure. Socrates was put to death on the charge of impiety and immorality - impiety in denying the gods of the state, and immorality in his teachings to the young men of the state. Jesus was put to death on the charge of blasphemy, and was regarded as the personification of impiety. The Inquisition persecuted and put to death on religious and theological grounds thousands of good persons. ${ }^{1}$ Only social harm can result from basing the state and its punishments upon religious belief. It means the exaltation of a priestly ruling class who must be accounted the vicegerents of God; it means the impossibility of experiments in government and the correction of mistakes through experience; it means the deterioration of the individual's powers - he is deprived of self-government and made the slave of a despot.

Punishment, then, must be founded, not on a religious creed, but simply on social well-being. The collective welfare is the only proper aim for the collectivity. The common good lies in bringing about such conditions that each member shall have full scope for realizing himself without diminishing other men's spheres of activity. The general weal consists in the largest amount of collective freedom with the least individual restraint. That organization of society should be sought which will make possible the full development and expression of human nature, the perfect realization of human capacities and possibilities. This is the aim that society should have in view in its corporate activity, and this prin-

${ }^{1} C f$. Mill, "On Liberty," chap. II, "The Liberty of Thought and Discussion." 
ciple of social well-being may be given as the ground for punishment or interference with the liberty of action of any offending member. "On this basis society has a reasonable justification to offer to the individual. This interference is necessary for the social well-being - the well-being of the individual himself and of all other individuals. The State exists not for one, not for a few, not for the majority, but for all. The true function of the State is to secure the fulfilment of the personal life of its citizens. The State is the vehicle by which the citizens attain to their full personal development. The State does not "interfere"; the State intervenes to protect the person and maintain the possibility for unhindered development of personality, by seeing that no individual encroaches upon other individuals, but that all have full opportunity of ethical self-realization. The principle of State action should be this: To secure such an organization of society that in it all persons may have full opportunity to live their largest lives." 1

The aim at expiation, then, is irrational, antisocial, and unjustifiable. Let us see next what measure of validity, when social utility is our criterion, can be ascribed to the principle of punishing for retribution.

Retribution is justified in part. That punishment should have regard for the past seems to be socially necessary. There is rather a fine point of discrimination here. Retributive infliction of pain

'McConnell, "The Ethics of State Interference in the Domestic Relations," in International Journal of Ethics, April, 1908, vol. XVIII, p. 374 . 
is right, not per se, but because socially useful. The point of view must not be limited to the past, but must comprehend also the future. The justification of punitive correction comes from its efficacy for the future; but this efficacy is dependent in part on punishment's being applied with a certain reference to the past. Punishment cannot be socially useful unless it is joined to past crime and corresponds in degree with the gravity of the crime. To be socially beneficial, it must not be applied to innocent persons and must not transcend the limits of social resentment for harm done.

The retributory aim, then, can be pronounced just, only in so far as socially useful. "Nemesis, the goddess of vengeance, is gone, and in her place stands Justice, with bandaged eyes, holding the scales. But as we gaze longer, the figure melts away, and there looms dimly in the background the colossal phantom of Society, with eyes wide open and the sword of self-defence in her hand." " Without the justification of social necessity, punishment would be as blameable as crime, judges and legislators would be as bad as feudists, jailers would be as guilty as the prisoners, and executioners would be as criminal as the assassins. It is the element of social utility in punishment that makes the difference between the punishing authorities and the criminals punished.

On the basis of social necessity, then, legal vengeance is justified. Crime unpunished is an element of destruction. Every one must know that the rights of other people set limits to his own will; and that he can not infringe them without being made to

${ }^{2}$ Ross, op. cit., p. 108. 
requite the wrong that he has done. Only in case people generally know that wrong-doing will meet with an adequate and certain return to the wrongdocr can society be protected. There must be good laws, and the penalties of the laws must be carricd out with certainty.

Punishment for retribution is socially useful, not only on account of its effects on criminals, but also because of its influence on other people. When punishment for a crime is not given, public indignation is apt to find a vent in a less regular and less discriminating mode of vengeance, like lynching. ${ }^{1}$ That retributive justice is socially useful is shown also by the following considerations: It gratifies the general and natural feeling of resentment; ' it serves "as an outlet, a kind of safetyvalve, for the indignation of the community"; ${ }^{3}$ it elevates the moral feelings of the public at large and strengthens men's disinterested sentiments; ${ }^{4}$ it "can alone produce the associations which make the conduct that incurs it, ultimately hateful in itself, and which by rendering that which is injurious to society, sincerely distasteful to its individual members, produces the fellowship of feeling which gives them a sense of common interest, and enables them to sympathize and co-operate as creatures of one kin." 5

The motive of deterrence in punishment is fully

${ }^{1}$ Cf. Westermarck, op. cit., vol. I, pp. 90, 91 .

${ }^{2} C f$. Adam Smith, "Theory of the Moral Sentiments," part II, section I, chap. I.

${ }^{3}$ Cf. Maine, "Ancient Law," 4th edition, 1870, p. 389.

"Cf. Kenny, op. cit., p. 29.

${ }^{5}$ Mill, "An Examination of Sir William Hamilton's Philosophy," 4th edition, p. 593. 
justified by the end of social utility. Society would be protected if criminals and would-be criminals were deterred from the commission of crime. This larger principle includes the principle of deterrence in its entirety, and has room left also for other aims. The notion of social utility changes and supplements the formula, "Punishment should achieve the maximum of deterrence," so as to read, "Punishment should achieve the maximum of social welfare with the minimum of suffering and loss."

The general purpose of accomplishing the greatest good allows punishment to be reformative as well as retributive and deterrent. Society's first duty is self-defence. It can usually defend itself best by making the criminal, where possible, a healthy and useful member of the social body. But where this is impossible, or where the attempt to do this endangers its own existence, its duty is plain, to protect itself. The reformation of the wrongdoer is highly gratifying if it can be brought about, but the object of primary concern is social protection. "Cure of the individual, if cure can be possible, but in any case defence of Society against his noxious freedom." 1

In some extreme cases, of course, protection can be accomplished only by measures which the Italian school described as either the "absolute" or the "relative" elimination of the criminal, that is, either by killing him, or by incarcerating him in a lunatic asylum, or by banishing him. ${ }^{2}$ But such absolutely incorrigible malefactors must be considered rare. The great majority of offenders, especially juvenile

${ }^{1}$ Gray, "Philanthropy and the State," p. 194.

${ }^{2} C f$. Ferri, op. cit., pp. $204 f f$. 
delinquents, must be regarded as criminal, not on account of defective brains, but as the result of defective education, especially home training. With all these, the aim of punishment must be not simply repression and deterrence, but reformation. "Where a virulent and highly infectious disease is epidemic among cattle, the practical question to be decided is whether the infected animals shall be quarantined and confided to the care of expert veterinarians for their recovery, or whether the danger to healthy animals shall be averted by the relentless slaughter of all suspects. The question of criminal contagion presents itself under a similar aspect. Reformatory methods are more humane, and, where they succeed, equally effective. Repression [or elimination] is possibly speedier and more certain. Cannot both methods be combined, in a single system, by dividing convicts into two groups, the corrigible and the incorrigible, and dealing with them separately?" 1 Elimination, either "absolute" or "relative" may be justified in the case of the incorrigible criminals, but as regards the great majority of offenders, those who are delinquent as the result of improper training, reformation is the course for society to pursue.

Usually it is only in the amendment of the antisocial will that a permanent protection from crime is to be found. A thorough-going prevention of injury implies the reformation of the injurer. Punishment that does not effect this is inadequate. The only way in which the state can permanently deter the malefactor from evil deeds is by educating him to better things. The social well-being is best served

'Wines, "Punishment and Reformation," pp. 252, 253. 
when the wrongdoer's character is reformed. Society must regard, not only the act, but also the person. It is true that for society there exists only a social responsibility, never a moral responsibility; but nevertheless it is the character that society must concern itself with and endeavor to reform. An act is never isolated, but is a symptom; and social precaution must consider the significance of this symptom, and must try to find out the internal condition of the person. Social precaution regards, not only the act and its motives, but also the will behind the act. This will, no matter what it may be from a metaphysical or ultimate point of view is mechanically and objectively a force which must enter into social calculations. By will or character is meant simply the system of tendencies of every sort which the individual customarily obeys and which constitute his social self. From another aspect the will or character may be estimated by the resistance which this interior energy is capable of presenting against anti-social motives or enticements. Until punishment has regenerated the heart of the criminal, until it has aroused the working of the intellectual and moral forces of his nature, it has not accomplished its full and sufficient result for society. The best means of preventing the recurrence of a wrong act is the improvement of the culprit. Society ought to endeavor to improve the mentality and morality of the deliquent. There must be an inner as well as an outer reformation. Restraint from crime is not all that society desires from its members. It needs active co-operation in the attainment of good. A former enemy. must be converted into a 
friend; a destructive social force into a constructive one.

The principle of social utility justifies treatment of crime and criminals with the aim also of prevention. The surest of all plans for protecting society from the ravages of crime would be to stop the manufacture of criminals. "A far-sighted policy, such as the training of the young, is preferable to the summary regulation of the adult. In the concrete these maxims mean that the priest is cheaper often than the detective, that the free library costs less than the jail, and that what is spent on the Sunday school is saved at Botany Bay. It is, then, strictly scientific to emphasize the ceremonial salutation of the flag in army or navy in order to economize in courtmartial, to prefer a little reform school for the boy to much prison for the man, and to reform the lawbreaker rather than to catch and convict him after a fresh offence." 1 "The only thing that can enable society to dispense with control is some sort of favorable selection. The way to create a short-clawed feline is not to trim the claws of successive generations of kittens, but to pick out the shortest-clawed cats and to breed from them. Similarly it is only certain happy siftings that can shorten the claws of man. . . The wiping out of the rampant by private enterprise makes way for the social reaction that converts the bully into the criminal and kills or jails him by constituted agents. It is processes like these, affecting the relative birth-rates or death-rates of the social and the anti-social classes, which solve the problem of order in such a manner that it stays

${ }^{1}$ Ross, op. cit., pp. 428, 429. 
solved. Mere control, on the other hand, is, like sustentation or defence, something that must go on in order that society may live at all. Men and women are socialized once for all, but in time the socialized units die while new, undisciplined persons keep swarming up onto the stage of action. The equilibrium achieved is perpetually disturbed by changes in the personnel of the group, and hence perpetually in need of being restored by the conscious, intelligent efforts of society." 1

The aim at prevention is the latest development in society's war against crime. ${ }^{2}$ The most far-seeing students of criminology are working at the problems of anticipating anti-social conduct and of erecting barriers in its way. Some of the most important of the means of prevention are: adequate educational institutions and facilities for the young of both sexes, playgrounds, prevention of child labor, reformatory institutions for juvenile offenders, juvenile court and probation system, care of destitute children, reform of the police system, suspension of sentence with surveillance without commitment to prison, better organization of the industrial order, regulation of immigration, national assimilation of immigrants, purification of home life, reform of political activity, abolition of intemperance, prevention of the transmission of hereditary defectiveness and criminality, care for discharged prisoners, improved housing, public hygiene and prevention of disease, remedies for unemployment, vocational training, institutions

I Ibid., pp. 60, 61.

${ }^{2} C f$. Henderson, "Preventive Agencies and Methods"; Wines, $o p$. cit., chap. XIV; Drähms, op. cit., chap. XIII; Boies, op. cit., chaps. XVI-XIX. 
of thrift and of insurance against the losses and burdens of accident, sickness, and death, control of prostitution, extension of the means of popular recreation, broadening and deepening of general culture, and the creation of higher interests among men and women than the elementary and animal appetites and passions.

Before closing this exposition of the object of punishment according to the principle of social utility, we must call attention to the fact that through the consideration of the various problems connected with society's object in punishing, we have been led gradually to face the great problem of society's right to punish. What makes punishment a right of society? On what ground does the justice of punishment rest? We are unable to reach a decision on these other questions until we have arrived at a decision on this question of right. So the problems which we have been considering must be held more or less in suspension through the remaining considerations of this book. Their solution depends on the solution of the more fundamental problems yet to be considered. Many criminologists and philosophers maintain that the penal function is not purely social but is moral as well. These persons set up the criterion of moral responsibility based on moral freedom. It therefore behooves us to undertake a searching analysis of the doctrines of freedom and responsibility in their relations to crime. 


\section{PART II \\ FREEDOM IN CRIME}

\section{CHAPTER VI}

\section{STATEMENT OF OPPOSED VIEWS}

Some notion of freedom and responsibility lies at the basis of any one's philosophy and practice of punishment. The practical importance of these conceptions has sometimes been denied; but is readily recognized if any one reflects about such an incident as the following: Two men are arrested for having committed murders. The one is placed in a lunatic asylum, is given a comfortable room, good food, medical attendance, exercise, reading matter, and visits from friends and relatives. The other is hanged or electrocuted. Why this difference of treatment? It is based on diverse conclusions as to the freedom and responsibility of the two murderers.

But is the disagreement in the conclusions as to the freedom and responsibility of these two criminals justifiable? Was the culprit who was hanged really "free"? Could he have helped doing what he did? Or was his deed determined as necessarily as was that of the other who is cared for so tenderly and sympathetically? Many of the world's greatest scholars and scientists maintain that all the acts of every one are necessitated with the same inevitable- 
ness as is a flash of lightning or the falling of a raindrop. Others declare that the acts of most men are expressions of a "free-will," which might have produced acts entirely the contrary of these. For example, James said: "What is meant by saying that my choice of which way to walk home after the lecture is ambiguous and matter of chance as far as the present moment is concerned? It means that both Divinity Avenue and Oxford Street are called; but that only one, and that one either one, shall be chosen. Now, I ask you seriously to suppose that this ambiguity of my choice is real; and then to make the impossible hypothesis that the choice is made twice over, and each time falls on a different street. In other words, imagine that I first walk through Divinity Avenue, and then imagine that the powers governing the universe annihilate ten minutes of time with all that it contained, and set me back at the door of this hall just as I was before the choice was made. Imagine then that, everything else being the same, I now make a different choice and traverse Oxford Street. You, as passive spectators, look on and see the two alternative universes, - one of them with me walking through Divinity Avenue in it, the other with the same me walking through Oxford Street. Now, if you are determinists you believe one of these universes to have been from eternity impossible: you believe it to have been impossible because of the intrinsic irrationality or accidentality somewhere involved in it. . . . I have taken the most trivial of examples, but no possible example could lead to any different result. For what are the alternatives which, in point of fact, offer themselves to human 
volition? What are those futures that now seem matters of chance? Are they not one and all like the Divinity Avenue and Oxford Street of our example?... Of two alternative futures which we conceive, both may now be really possible; and the one become impossible only at the very moment when the other excludes it by becoming real itself. .. . The question relates solely to the existence of possibilities, in the strict sense of the term, as things that may, but need not, be. Both sides admit that a volition, for instance, has occurred. The indeterminists say another volition might have occurred in its place: the determinists swear that nothing could possibly have occurred in its place." 1

James maintained that the indeterminist is right, that on leaving the lecture hall he could have walked home by either road. The determinist declares that it was no more possible for James to have walked home by a road other than the one he walked by, than it was possible for him to have talked to his attendant in just any language whatsoever and on just any subject whatsoever. In other words, the route he took was determined by causes which made that route the only one possible, just as the topic of conversation and the language in which it was held were fixed by past events which did not permit any different result. The indeterminist or freewillist asserts that at any moment of action dual possibilities are open to the actor. He may strike out upon one line of conduct, but it is equally possible for him to take some other. His will at any

"James, "The Dilemma of Determinism," in "The Will to Believe," pp. 150-157. 
moment is free. It is not determined by what has gone before. It is not caused, constrained, determined, but is itself a first cause, spontaneous, free.

The free-willist regards a man as having come into the world as a moral blank, so that, in virtue of his "free-will" considering objects which have neither to be sought nor avoided as the result of his nature and circumstances, he may "choose" whether he is to be an angel or a devil or anything else that may lie between the two.'

Practical action is bound to be modified by the view which any one takes on this matter of freedom or determinism. Whenever a determinist regards an act, he feels justified in inquiring for its causes. He looks for the motives which determined the will of the actor. The free-willist, on the contrary, may think such a procedure useless. He thinks that the will was free, and not necessitated by antecedent events. A man has stolen something: the determinist inquires, "Why did this man steal?" The free-willist replies, "Because he wished to." The determinist asks, "What caused him to wish to steal?" The free-willist answers, "Nothing; nothing caused him to steal, or to want to steal. He could have refrained from stealing. He stole simply because he wanted to steal. That is the end of the matter." A drunkard is arrested and brought up for trial. The determinist judge says, "This man inherited an uncontrollable thirst for alcohol; he needs to go to a sanatorium for treatment and cure." The free-willist judge asserts, "It does not make any difference how many generations of this man's ances${ }^{1} C f$. Schopenhauer, "On Human Nature," p. 87. 
tors drank whiskey; he need not have drunk it, and ought not to have drunk it. Let him be punished with the maximum imprisonment." A girl prostitute is arrested: the determinist policeman says, "Don't be too hard on her, judge; her mother is a prostitute and keeps a house." The free-willist judge replies, "That does not matter at all. She could have refrained from being a prostitute. Every human being is endowed with freedom of will, with the capacity of choosing whether or not the conceived action shall be done. When this girl was called on to make the choice, she ought to have chosen the other way. Let her be punished to the full extent of the law."

Each side in this controversy about free-will and determinism has tried to show that morality and theism depend on the reception of the doctrine championed. For example, Naville says: "In order to appreciate the gravity of the question that is brought up, it is enough to understand that without an element of liberty there is no responsibility, and that absolutely to deny responsibility is to undermine the foundations of all our moral and social ideas; it means that we should be willing to strike out of the dictionary the words, duty, good and bad morals, or at least give these words, if they should be retained, a wholly different meaning from that which mankind has always given them." 1 Hamilton taught: "It is self-evident, in the first place, that if there be no moral world, there can be no moral governor of such a world; and in the second, that

'Naville, "Le libre arbitre, étude philosophique" (Genève, 1898), quoted by Dubois, op. cit., p. 50 . 
we have, and can have, no ground on which to believe in the reality of a moral world, except in so far as we ourselves are moral agents. ... Man is a moral agent only as he is accountable for his actions, - in other words, as he is the object of praise or blame; and this he is only, inasmuch as he has prescribed to him a rule of duty, and as he is able to act, or not to act, in conformity with its precepts. The possibility of morality thus depends on the possibility of liberty; for if man be not a free agent, he is not the author of his actions, and has, therefore, no responsibility, no moral personality at all." A good statement of this argument was formulated by Hume as follows: "If voluntary actions be subjected to the same laws of necessity with the operations of matter, there is a continued chain of necessary causes, pre-ordained and predetermined, reaching from the original cause of all to every single volition of every human creature. No contingency anywhere in the universe; no indifference; no liberty. While we act, we are, at the same time, acted upon. The ultimate Author of all our volitions is the Creator of the world, who first bestowed motion on this immense machine, and placed all beings in that particular position, whence every subsequent event, by an inevitable necessity, must result. Human actions, therefore, either can have no moral turpitude at all, as proceeding from so good a cause; or if they have any turpitude, they must involve our Creator in the same guilt, while he is acknowledged to be their ultimate cause and author. For as a man, who fired a mine, is answer-

'Hamilton, "Lectures," i, 32, 33, quoted by Mill, op. cit., p. 566. 
able for all the consequences whether the train he employed be long or short; so wherever a continued chain of necessary causes is fixed, that Being, either finite or infinite, who produces the first, is likewise the author of all the rest, and must both bear the blame and acquire the praise which belong to them. .. Ignorance or impotence may be pleaded for so limited a creature as man; but those imperfections have no place in our Creator. He foresaw, he ordained, he intended all those actions of men, which we so rashly pronounce criminal. And we must therefore conclude, either that they are not criminal, or that the Deity, not man, is accountable for them. But as either of these positions is absurd and impious, it follows, that the doctrine from which they are deduced cannot possibly be true, as being liable to all the same objections." 1

It would be equally easy to quote passages from determinists to the effect that determinism is the only satisfactory basis for morals and religion. It will doubtless suffice merely to call attention to the fact that "nearly all the theologians of the Reformation, beginning with Luther, and the entire series of Calvinistic divines represented by Jonathan Edwards, are proofs that the most sincere Spiritualists may consistently hold the doctrine of so-called Necessity." 2

This is doubtless the proper place to notify the reader that the author docs not intend to bring God into the following argument at all. He regards any such argument as entirely worthless; and he has

\footnotetext{
${ }^{1}$ Hume, op. cit., pp. 99, 100.

${ }^{2}$ Mill, op. cit., p. 568.
} 
absolutely no sympathy with the practice of trying to bribe the reader by the assurance that such and such a doctrine is the only valid support for some religious view or prejudice. 


\section{CHAPTER VII}

\section{THE PSYCHOLOGY OF WILL, MOTIVE, AND CHOICE}

Concerning the nature of will and volition, the free-willist and the determinist hold entirely different views. The free-willist believes that over and above the particular acts of volition there is a certain entity called the will, which is, as it were, a sort of personage within the human person. This will is free. It is an autocrat. Various motives appeal to it. It sits in judgment over them, and "decides" freely which shall be followed. Diverse roads of action lie before it: it "chooses" freely which one it will take. Goodness and badness are offered to it: it "prefers" the one rather than the other.

The free-willist implies that the will is a distinct entity whenever he ascribes "freedom" to it. Only such a conception is compatible with his constant comparison of the will to a person, and of freedom of the will to the liberty of personal action, and of determination of the will to constrained personal behavior. The determinist, however, maintains that we must not think of the will as a person or as an independent existence, but only as a sum of processes. Science proceeds on the principle that the real is what can be experienced, what can be observed and classified. Now, what science observes and classifies is not "the will," but simply volitional processes. There are mental events, and there are 
physical events; and science can trace the sequence of antecedents and consequents in either series, as well as the relation of the one series to the other. Psychology's success in accounting for all the phenomena of volition without the hypothesis of "the will" as an active agent suggests very forcibly the superfluity of such a hypothesis. Scientific psychology has taken away the occupation of the metaphysical "will."

Processes must not be erected into independent existences. Present-day psychology does not admit the existence of such entities as "the will," which wills, "the intellect," which thinks, and "the sensibility," which feels, - as it were, three persons within the one person. It recognizes only distinct processes, elementary and compound. And no one of these - whether it be a feeling-process, or a thought-process, or a volition-process - is properly called "free." It is connected with, and dependent on, others. When we regard any of the separate acts of volition, and notice its connection with antecedent and subsequent processes, we perceive how incorrect it is to speak of it as "free." A volition is no more "free" from connection with other psychical activities than a man's body is "free" from relationship with other physical matter. A volition has no more "liberty of choice" as to whether it will depend on other mental processes, than a man's body has "liberty of choice" as to whether it will touch other matter.

Locke, although speaking generally in the language of "the faculty psychology," once stated pretty well the true nature of the case, and his quaint way 
of expressing it would hardly be found objectionable by present-day psychology. "It is as insignificant to ask whether man's will be free, as to ask whether his sleep be swift, or his virtue square: liberty being as little applicable to the will, as swiftness of motion is to sleep, or squareness to virtue. Every one would laugh at the absurdity of such a question as either of these; because it is obvious that the modifications of motion belong not to sleep, nor the difference of figure to virtue; and when any one well considers it, I think he will as plainly perceive that liberty, which is but a power, belongs only to agents, and cannot be an attribute or modification of the will. . . . Who is it that sees not that powers belong only to agents, and are attributes only of substances, and not of powers themselves? So that this way of putting the question, viz., Whether the will be free? is in effect to ask, Whether the will be a substance, an agent? or at least to suppose it, since freedom can properly be attributed to nothing else." 1

The volition-process is thoroughly dependent on the feeling-processes and the thought-processes. This is true of it in all its stages, from the lowest form of impulsive action to the most highly developed form of decision and resolution. Volition is a function of the supreme brain-centres. Hence it varies in quantity and quality as its cause varies; it is strengthened by education and exercise; it is enfeebled by disease; it decays with decay of structure; and it always needs for its outward expression the educated agency of the subordinate motor centres.

'Locke, "An Essay Concerning Human Understanding," Book II, chap. XXI, secs. 14-16. 
The determinist thus argues against the free-willist that the doctrine of freedom of the will rests on a wrong conception of the nature of will. Will is not to be considered an entity, but only a compound of psychical processes. There is never a single and unchanging will. Each individual has many wills, varying according to age, state of health, and other conditions of life. All the separate acts of volition are to be regarded, not as "free," but as causally related to other psychical processes.

Motives, also, are differently viewed by the freewillist and the determinist. The free-willist takes objection to the claim that the will is determined by motives. According to him, it sits in judgment over them, and can set aside the strongest in favor of the weakest, or can give a decree in defiance of any and all. The determinist thinks the will entirely determined by motives - always obedient to the strongest. Motives are dependent on emotions and ideas, feelings and sensations, instincts, desires, passions, heredity, environment, and education. The determinist believes that every action takes place in accordance with the preponderance of influence from these various sources. The free-willist, however, thinks that the will judges every action immediately, without determination by antecedent events. Each act takes its origin, not in past inheritance and experience, but simply in a present free choice of the will. The will has no solidarity with nature. It receives from God all that it has and is. It does not submit to the influences from here below. It acts in view of the objects above. It carries in itself the reason and cause of its acts. It is 
not a mere link in a chain of causes and effects, but is a first cause.

The free-willist hinges all morality on the existence of the free-will. I am not a moral person unless I can say, "This is my own act. I freely choose it. My choice is not determined by the past. It is freely made, perhaps in despite of any and all motives that are present. To say that I am determined by motives is to rob me of my freedom and originality. It is to make of me a passive link in an inevitable chain of sequence. It is to make of me a thing, and not a person, not a free moral agent." The determinist argues that the word freedom has no meaning other than that of the absence of external constraint. If I am compelled by another person to act, then I may not be said to be free. But the word freedom is out of place when used in connection with obedience to motives. Various motives concur and compete in urging me to act. The resulting volition shows that one group of them has been stronger than the others. It is wrong to call this volition either free or unfree. Motives are not external to a man, and are not alien forces which move him in a direction contrary to his wishes. So it is incorrect to say that if he is determined by motives he is in so far not "free." They are nothing apart from him. Acting under the determination of motives dependent on emotions, feelings, appetites, desires, passions, aversions, ideas, associations of ideas, memories, and habits, is not the same as acting under external compulsion, and is not inconsistent with self-determination and moral responsibility. It is absurd to give such a meaning to the word freedom as to 
indicate that a man ought to be able to choose to act in a direction contrary to the strongest motive or strongest group of motives that happen to be present to his mind at the moment of action.

Thus the free-willist commits not only the error of personifying the will as an entity distinct from the particular processes of volition; he is guilty also of the mistake of regarding determination by motives as a species of external constraint inconsistent with self-determination and moral responsibility.

To will something means that a volition arises in consequence of a consciousness of an object which becomes a motive and aim of action. A volition is essentially simply a form of reaction upon the consciousness of an object; and could not take place without this, since then both occasion and material for the reaction would be lacking. When this object is present in consciousness, under exactly the same conditions, that particular volition must ensue, it cannot fail, it cannot be different, it cannot be displaced by some other volition. In short, the will is necessarily determined by motives, and has not "the liberty of indifference," the ability, in the presence of motives, either to act or to refrain from acting. The process of deliberation is nothing other than the conflict of motives in the arena of consciousness. The various motives contend against one another for the mastery, until one proves itself the victor and drives the others off the field and determines the will. This result is called a "decision." The whole process, however, takes place with necessity.

The determinist, so far from supposing each act an absolute commencement, a creation ex nihilo, by the 
will as a first cause, maintains that each act is causally related with antecedent, simultaneous, and subsequent events. He would seek out the connections of the act with some desire or group of desires which produced it, and would then trace these back to their causes, and so on in infinite regression. A volition is not something isolated, unconnected, independent of preceding psychical processes. A spring could not say of a drop of water which it sent forth, "That is $m y$ drop of water. It derived all its qualities from me, from a free choice, a free decision of my will. I have decided freely whether that drop should be pure or impure, saline or sweet, alkaline or acid, sulphurous or chalybeate." Any one would know that the drop of water did not have an absolute commencement at the mouth of the spring; but that it owed its qualities to the soils and ores through which it passed; and that the course of its history might be retraced to the snows of the mountains, to the clouds above, to the ocean beyond. It is the same with a volition. A person cannot properly say, "That is my volition. It derived all its qualities from a free choice, a free decision of my will. My will decided, as a first cause, whether this volition was to be socially beneficial or harmful." The history of that volition may be retraced among appetites, desires, passions, education, training, and heredity. It can be followed back indefinitely into the past, just as it can be followed on indefinitely into the future. The proper conception of it is as an intermediary link in a sequence of causes and effects without beginning and without end.

The free-willist asserts that the will is not deter- 
mined by motives, but is the free creator of its volitions, choices, and decisions. It stands out as separate and distinct from the natural order which is under the dominion of cause and effect. Each voluntary act must be regarded as something absolutely new in the universe, deriving its origin solely from the will, which is wholly independent of antecedent events whether external or internal. The will is an uncaused cause. It sends forth its expressions entirely of itself, free from determining influence. Every choice or decision is an "absolute commencement" of a new series of occurrences.

The determinist, on the other hand, thinks that a correct simile for the will is that of a balance scale which can never stir from its equilibrium unless something is laid in one of the scale pans and becomes a cause of the movement. ${ }^{1} \quad$ As little as the scale could set itself in motion, so little could the will produce of itself an action. Volition must be motived by something which positively causes action. The determining forces which act upon the will are of two kinds, - those that come from without, namely, from circumstances, and those that come from within, namely, from character, that is, from the inclinations and tendencies to action which are essential in the man, and by virtue of which the external conditions are shaped in their influence as motives. From all this it is obvious that the will is not "free." The turning of the balance is determined by the weights that are placed upon it. The causality runs back, therefore, to whoever or whatever laid the tendencies in the character and determined the occasions and induce-

${ }^{1}$ Cf. Schopenhauer, "Ueber die Freiheit des Willens," S. 73. 
ments of the environment. "Saying that the will is self-determined, . . . gives no idea at all, or rather implies an absurdity, viz: that a determination, which is an effect, takes place without any cause at all. For, exclusive of everything that comes under the denomination of motive, there is really nothing at all left that can produce the determination. Let a man use what words he pleases, he can have no more conception how we can sometimes be determined by motives, and sometimes without any motive, than he can have of a scale being sometimes weighed down by weights, and sometimes by a kind of substance that has no weight at all, which, whatever it be in itself, must, with respect to the scale be nothing." 1

The free-willist claims the ability to do or not to do any action. He says, Of course I could, if I willed it. The determinist replies, That is just it. You have the ability to do any action, on one condition, namely, if you will it. You have the ability to will it, on one condition, namely, if you desire it. You have the ability to desire it, on one condition, namely, if you have an antecedent want which causes this desire. And so on ad infinitum. The will must be conceived simply as an intermediary agent between motives and actions. The search from will to motive, from motive to emotions, from emotions to feelings and ideas, from these to sensations, leads us back into eternity, in order to find the first cause. The freewillist's claim to be able to do any action on condition that he will it is like a paralytic's claim to be

'Priestley, "The Doctrine of Philosophical Necessity," 2d edition, p. 43. 
able to run on condition that he move his legs, and able to move his legs on condition that his nerves and muscles function, and able to make his nerves and muscles function on some other condition.

The consciousness of free choice is nothing more than the consciousness of the competition among motives. It depends upon the fact that in deliberation two or more tendencies to action are present to the mind at once. The consciousness of deliberation, far from being a ground for assuming an arbitrary or undetermined power of volition, is exactly what should be expected to accompany the process of determination by various and conflicting motives. If a body is pulled to the right with a force of twelve pounds, and to the left with a force of eight, it moves to the right. Imagine that body a mind aware of the influences which act upon it; it will be conscious of going in the direction of the strongest motive, that is, the motive which, for whatever reason, appeals to it most; and in doing so it will, just because it is a mind, be aware of deliberation and decision. The power of choice is, therefore, not an unexplained faculty incompatible with determination. Which motive is selected is wholly determined, and is dependent upon the character, which cannot choose otherwise than it does. We cannot, therefore, say that there was a freedom of choice in the sense that we might have chosen otherwise. The freedom of choice lies in the choosing. The feeling that, whatever we really did, we were free to do otherwise depends on an illusion. A different action from the actual one is conceivable: there is a logical alterna- 
tive to everything. But if the agent believes that he, with his character and under his circumstances, could have acted otherwise than he did, he confuses the feeling of deliberation and choice with this merely logical possibility. ${ }^{1}$

Since the discussion of the nature of will and volition concerns a question of psychology, it would be well to consult some high psychological authority. An extremely clear statement has been given by Wundt, which may be abridged to the following:

"A volitional process is thus related to an emotion as a process of a higher stage, in the same way that an emotion is related to a feeling. Volitional act is the name of only one part of the process, that part which distinguishes a volition from an emotion. The way for the development of volitions out of emotions is prepared by those emotions in connection with which external pantomimetic expressive movements appear. These expressive movements appear chiefly at the end of the process and generally hasten its completion. . . The fundamental psychological condition for volitional acts is, therefore, the contrastbetween feelings, and the origin of the first volitions is most probably in all cases to be traced back to unpleasurable feelings which arouse external movements, which in turn produce contrasted pleasurable feelings. The seizing of food to remove hunger, the struggle against enemies to appease the feeling of revenge, and other similar processes are original volitional processes of this kind. The emotions coming from sense-feelings, and the most widespread social emotions such as love, hate, anger, and revenge, are thus, both in men and animals, the common origin of will. . . .

"The richer the ideational and affective contents of experience, the greater the variety of the emotions and the wider the sphere of volitions. There is no feeling or emotion that does not in some way prepare for a volitional act, or at least have some part in such a preparation. All feelings, even those of

${ }^{1}$ Cf. Alexander, op. cit., pp. 339, 340. 
a relatively indifferent character, contain in some degree an effort towards or away from some end. . . .

"The single feelings in an emotion which closes with a volitional act are usually far from being of equal importance. Certain ones among them, together with their related ideas, are prominent as those which are most important in preparing for the act. Those combinations of ideas and feelings which in our subjective consciousness are the immediate antecedents of the act, are called motives of volition. Every motive may be divided into an ideational and an affective component. The first we may call the moving reason, the second the impelling feeling of action. When a beast of prey seizes his victim, the moving reason is the sight of the victim, the impelling feeling may be either the unpleasurable feeling of hunger or the race-hate aroused by the sight. The reason for a criminal murder may be theft, removal of an enemy, or some such idea, the impelling feeling the feeling of want, hate, revenge, or envy. . .

"The combination of a number of motives, that is, the combination of a number of ideas and feelings which stand out from the composite train of emotions to which they belong as the ideas and feelings which determine the final discharge of the act-this combination furnished the essential condition for the development of will, and also for the discrimination of the single forms of volitional action.

"The simplest case of volition is that in which a single feeling in an emotion of suitable constitution, together with its accompanying idea, becomes a motive and brings the process to a close through an appropriate external movement. Such volitional processes determined by a single motive, may be called simple volitions. The movements in which they terminate are often designated impulsive acts. . . . .

"When several feelings and ideas in the same emotion tend to produce external action, and when those components of an emotional train which have become motives tend at the same time toward different external ends, whether related or antagonistic, then there arises out of the simple act a complex volitional process. In order to distinguish this from a simple volitional act, or impulsive act, we call it a voluntary act. 
"Voluntary and impulsive acts have in common the characteristic of proceeding from single motives, or from complexes of motives that have fused together and operate as a single unequivocal impulse. They differ in the fact that in voluntary acts the decisive motive has risen to predominance from among a number of simultaneous and antagonistic motives. When a clearly perceptible strife between these antagonistic motives precedes the act, we call the volition by the particular name selective act, and the process preceding it we call a choice. The predominance of one motive over other simultaneous motives can be understood only when we presuppose a strife in every case. But we perceive this strife now clearly, now obscurely, and now not at all. Only in the first case can we speak of a selective act in the proper sense. The distinction between ordinary voluntary acts and selective acts is by no means hard and fast. In ordinary voluntary acts the psychical state is, however, more like that in impulsive acts, and the difference between such impulsive acts and selective acts is clearly recognizable.

"The psychical process immediately preceding the act, in which process the final motive suddenly gains the ascendency, is called in the case of voluntary acts resolution, in the case of selective acts decision. . . .

"In the theories of volition given by older psychologists theories that very often cast their.shadows in the science of to-day - we have a clear exhibition of the undeveloped state of the methods of psychological observation. . . . Will was thus limited to the voluntary and selective actions. Furthermore, the one-sided consideration of the ideational components of the motives led to a complete neglect of the development of volitional acts from emotions, and the singular idea found acceptance that volitional acts are not the products of antecedent motives and of psychical conditions which act upon these motives and bring one of them into the ascendency, but that volition is a process apart from the motives and independent of them, a product of a metaphysical volitional faculty. This faculty was, on the ground of the limitation of the concept volition to voluntary acts, even defined as the choosing faculty of the mind, or as the faculty for preferring one from among the various motives that influence the mind. Thus, instead of de- 
riving volition from its antecedent psychical conditions, only the final result, namely, the volitional act, was used to build up a general concept which was called will, and this class-concept was treated in accordance with the faculty-theory as a first cause from which all concrete volitional acts arise." 1

A very strong testimony to the determination of volitions is furnished by the results of abnormal psychology. Many of the students of psychiatry have reached the conclusion that all the troubles of the mind have a basis in some disorder of the physical organism, in some disturbance in the organization of the nervous system. Every psychic reaction is determined by physiological stimuli coming from outside under some form or other. Man's "actions" are, strictly speaking, simply "reactions." He can have no psychic manifestations without concomitant cerebration, without physio-chemical modification of the brain cells, without organic combustion. The celebrated aphorism could be changed to say, in truth, There is nothing in the mind which is not in the brain, "nihil est in intellectu quod non sit in cerebro." 2 The organ of thought is the brain. Without brain, there is no psychical functioning, - there are no sensations, memories, ideas, or volitions. Whatever affects the brain influences mental phenomena. It is a matter of common observation how volitions are influenced by the nervous system when under the stimulation of tea, coffee, alcohol, or narcotics. Abnormal or pathological conditions increase the impulsiveness of volitions and often turn them into dangerous channels.

'Wundt, "Outlines of Psychology," tr. Judd, 2d revised English edition, pp. 201-213.

${ }^{2} C f$. Dubois, op. cit., p. 37; Ribot, "Les maladies de la personnalite," p. 151. 
Ribot, one of the great authorities in abnormal psychology, has made extensive investigations of diseases of will, diseases of memory, and diseases of personality. His studies of mental dissolutions are psychologically very instructive. He finds disorganization in the mental life always consequent upon disorganization in the physical organism. He regards conditions of consciousness as dependent on conditions of the organism, hence the problems of psychology as ultimately problems of biology. "It is the physical organism, with the brain, its supreme representation, that is the real personality. It contains in itself the remains of all that we have been and the possibilities of all that we shall be. In it is implanted the individual character in its entirety, with its active and passive aptitudes, its sympathies and antipathies, its genius, its talent or its stupidity, its virtues or its vices, its torpor or its activity. What emerges of it to consciousness is but little in comparison with what remains shrouded though nevertheless active. The conscious personality is never more than a feeble part of the physical personality. . . . The unity of the ego, in the psychological sense, is therefore the cohesion, during a given time, of a certain number of clear states of consciousness, accompanied by others less clear and by a crowd of physiological states which, without being accompanied by consciousness, like their fellows, nevertheless act as much as or more than they."

'Cf. Ribot, op. cit., p. 172.

${ }^{2}$ Ibid., pp. 170-172. Compare the following statement by Giddings. "Before many years, I believe we shall discover that at least 90 per cent. of human action is involuntary response to stimuli. Like the summit of the ponderous iceberg, which only rears a small 
In the conclusion of his study of diseases of will, he says, regarding the freedom of the will: "Volition is a final state of consciousness, which results from the co-ordination more or less complex of a group of states, conscious, sub-conscious, or unconscious (purely physiological), which, united, translate themselves by an action or an inhibition. Co-ordination has for its principal factor character, which is nothing but the psychical expression of an individual organism. It is character that gives to co-ordination its unity,-not the abstract unity of a mathematical point, but the concrete unity of an agreement. The act by which this co-ordination is made and affirmed is choice, founded on an affinity of nature. The will which the interior psychologists have so often observed, analyzed, and commented on, is for us only a simple state of consciousness. It is only an effect of that psycho-physiological process, so often described, of which only a part enters into consciousness under a form of deliberation. Moreover, it is the cause of nothing. The acts and motions which follow it result directly from the tendencies, feelings, perceptions and ideas which have ended in co-ordinating themselves in the form of a choice. It is from this group that all the efficacy comes. In other words, and not to leave anything equivocal, the psycho-physiological process of deliberation ends partly in a state of consciousness, volition, and partly in a group of movements or inhibitions. The 'I

portion of its bulk above the waves, the mind of man seems to dominate and direct his activity; but in reality, his conduct is the result of mighty forces little seen or guessed at upon the surface." (Giddings, quoted in Parsons, "Responsibility for Crime," p. 68.) 
will' states a situation but does not constitute it. ... If any one persists in regarding the will as a faculty, an entity, there is nothing but obscurity, embarrassment, contradiction. He is ensnared with a question badly put. If, on the contrary, he accepts things as they are, he is at least freed from artificial difficulties. He does not have to ask, as did Hume and so many others, How can an 'I will' cause my limbs to move? That is a mystery that needs not to be explained, because it does not exist, - for the will is not a cause in any degree. The secret of how acts are produced should be looked for in the natural tendency of feelings and ideas to translate themselves into movements. We have here only an extremely complicated case of the law of reflexes, in which between the period of excitation and the period of movement there appears an important psychical fact-volition-showing that the first period ends and the second begins." 1

${ }^{1}$ Ribot, "Les maladies de la volonte,", pp. 178-180. 


\section{CHAPTER VIII}

\section{THE NATURE OF MENTAL CAUSATION}

THE relation between cause and effect is nearly always thought of in the same way as a mechanical transfer of motion from one body to another, and as containing an element of external constraint. But a thorough analysis of the causal relation shows that the idea need have nothing to do with coercion. The connection between cause and effect has no other essential content than constant, regular succession of events in time. No transfer of properties from one element to another is necessary. There is no overmastery and compulsion of one element by another. What alone takes place is a corresponding change of elements, simply a "universal concomitance."

That is a false notion of the causal relation which regards a cause as pushing an effect forward or using force on it. All that we know of cause and effect is a regular sequence of phenomena. The statement that $A$ and $B$ act and react upon each other signifies only that when $A$ enters upon state $a^{\prime}, B$ enters upon state $\mathrm{b}^{\prime}$, and conversely. A uniform concurrence of changes at different points of the world is all that causation and reciprocal action mean.

Hume has, once for all, emptied the conception of causation, for the scientific mind, of all content of compulsion and mysterious transfer of qualities from one object to another. He said that we can arrive 
at a correct and precise idea of the nature of necessity by carefully considering whence the notion of necessity arises when we ascribe it to the operation of natural phenomena. If the scenes of nature were continually shifted in such a manner that no two events ever bore any resemblance to each other, but every object was entirely new and without any likeness to anything that had been seen before, we should never conceive a connection between objects or attain the least idea of causation. We might say, under such conditions, that one thing followed another, but never that one was produced by the other. The relation of cause and effect would be utterly unknown. Our idea of necessity and causation arises, therefore, wholly from the uniformity observable in the operations of nature, where similar events are constantly connected with similar antecedent events, so that the mind is led to infer the one from the appearance of the other. These two characteristics compose the whole of that necessity which we constantly ascribe to occurrences. We have no notion of causation or necessity besides constant connection of events or objects, and the consequent inference from one to the other. A "cause" is that after which anything constantly exists; and this is all that we know of it. This constancy forms the very essence of necessity; nor have we any other idea of the causal relation. ${ }^{1}$

There are certain striking differences in the kinds of causation. Objects are usually divided into inorganic (lifeless) and organic (living). The latter are subdivided into plants and animals. Man stands at the height of development of animal life. The ${ }^{1}$ Cf. Hume, op. cit., pp. 84, 85, 100. 
ways in which these different classes of objects exemplify the law of causation are various. Corresponding to the three distinctions between inorganic bodies, plants, and animals, there are three diverse modes of causation, namely, through causes in the strictest sense of the word, through stimuli, and through motives. ${ }^{1}$ The general nature of causation is not in the least impaired in any of these modifications. A cause in the narrow sense of the word applies to changes in mechanical, physical, and chemical bodies. A stimulus is our designation for a cause that effects alteration and development of plants and of vegetative functions of animal bodies. Stimuli of this sort are light, air, nourishment, drugs, fructification. A motive is that kind of cause which effects changes in the action of animal beings through influencing their intelligence. It obtains in the case of those who have reached a stage of development where numerous and complex needs make it difficult to attain satisfaction on occasion, but render necessary an intricate and diligent search for the means of satisfaction, in other words, action that is not simply a reaction upon stimuli, but is caused by intellectual perception, comprehension, deliberation, and decision. On this account, in such beings, the susceptibility to stimuli is supplemented by a susceptibility to motives, and by appropriate agency therefor, namely, intellect or consciousness, in innumerable grades of development, with its physical correlate, the nerve-system and brain. An animal reacts in response to feelings and ideas. When action takes place as the result of perceptions, desires, ambitions, ${ }^{1} C f$. Schopenhauer, "Ueber die Freiheit des Willens," S. 28-33. 
pleasures, pains, ideals, emotions, or any other content of consciousness, it is said to be caused by motives.

Bearing in mind the various modes of causation, we perceive that it obtains even though effects may be very dissimilar to their causes. It is absurd to expect causation to present the same phenomena in the case of plants and animals as in the case of inorganic bodies. Yet the advocates of free-will demand a demonstration of the law of conservation of energy and of other physical laws as governing man's obedience to motives; and when this proof is not forthcoming they claim that man is exempt from the reign of law. In the mechanical world, if a moving body strikes a body at rest, the first loses as much motion as it imparts to the second, there is a transfer of properties, the cause passing over into the effect. But such a palpable relation between antecedent and consequent becomes less and less clear as action becomes more complex; for example, when heat produces expansion, melting, hardening, burning, combustion.

When we pass to causation through stimuli, the relation between cause and effect becomes more heterogeneous, incommensurable, unintelligible; for example, in the influence upon plants of light, heat, air, and soil, all of which affect vegetation in infinitely complex ways; nevertheless the relation between cause and effect does not lose any of its constancy and inevitableness. As necessarily as a free body is set in motion when struck, seedcorn germinates under proper influences of soil, heat, moisture, and air. The causes are more obscure; the 
effects more unlike their causes; but the necessity of the causal dependence is not in the least impaired. When we pass to the sphere of motivation in animal action, the relation between antecedent and consequent is still more intricate. In the case of the lower animals, however, as when the moth flies into the flame, cause and effect are both apparent, and nobody thinks of freedom of choice. But when the motives work not immediately through sense perception, but through thought, through memory, reflection, and deliberation, over great distances of space and time, there seems a temptation to regard the law of causation as broken. Really, however, action without cause is as impossible in the case of man as in the case of a mechanical machine. If we could observe and know the nature of a particular person and the kind and strength of the motives acting upon him, as thoroughly as we can observe and know the length of beams, the diameter of wheels, and the power of the motive force of a material machine, we could calculate exactly how he would act. But because he is moved by abstract ideas, which are not palpably connected with any immediately present space or time, we permit ourselves to be misled and to think that what he does could just as well not be done, that his will decides of itself, without determinant, and that each act is a first commencement of a series started by that will. It is neither metaphor nor hyperbole, but perfectly dry and liberal truth, that as little as a billiard ball could move before receiving an impulsion, just so little could a man rise from his chair without being impelled by some motive. When such a force acts upon him, however, 
his rising is as necessary and inevitable as the rolling of the billiard ball after being struck. To expect that any one should do something to which no interest induces him is like expecting that a stick of wood should move itself to me without being drawn by some string. If these deterministic assertions meet with stiff-necked contradiction, the easiest way of showing their truth would be to have some one suddenly shout in an assemblage of people, "The house is on fire!" then the contradictor would have to admit that a motive may be equally powerful in ejecting people from a house as any kind of mechanical cause. ${ }^{1}$

If causation means only the regular harmony between the changes of elements, then it is plain that it prevails in the mental world no less than in the physical. We cannot easily detect uniformity here, or formulate its laws; but it exists. Isolated or lawless occurrences do not take place in the mental any more than in the physical sphere. Each element is definitely related to antecedent, simultaneous, and succeeding elements. From the same antecedent, under wholly identical inner and outer circumstances, the same consequent invariably ensues. The same idea, the same emotion, and the same volition result from the same stimulus. Volitions follow determinate antecedents with the same constancy and certainty as physical effects follow their physical causes. Among these antecedents are appetites, desires, aversions, passions, habits, and inherited tendencies, in connection with external circumstances suitable to call these internal incentives into action.

${ }^{1} C f$. ibid., S. $36-65$. 
Psychical events take place in accordance with law, that is, with regularity or uniformity. The law of causation is not broken in the case of human volitions. There is no uncaused occurrence. Every event must have been preceded by others sufficient to bring it about. Given the inducements to action which are present to an individual's mind, and given likewise the character of the individual, the manner in which he will act could be unerringly foretold. If we knew a person thoroughly and knew all the incentives that are acting upon him, we could predict his conduct with as much certainty as we can foretell an eclipse of the moon.

Nothing can happen in the mental realm without some adequate cause to explain why it takes place in this particular way and not in some other. The writing of a poem, the forging of a note, the burglary of a house,the assassination of a king, - all have their adequate and determining causes as truly as have the forming of a dewdrop, the fading of a flower, the eruption of a volcano.

If a volition is regarded as an act of choosing, of resisting certain impulses and of yielding to others, is it proper to call it "free"? Such an act is always determined by the attraction or repulsion with which its idea is vested. If we resist or submit, we are impelled to do so either by the motor tendencies of sensation or by intellectual motives. We always yield to an attraction or a repulsion. "It is the liberty of a piece of iron attracted by a magnet." Whatever we do we are always obeying sentiments and ideas. Upon analysis, any action, whether the devotion of a martyr or the most shocking crime, 
will be found to have been determined by some imperious influence. In the one case it is native nobility of feeling, due to heredity and strengthened by education, by the moral and religious convictions that have been cherished in the family and in the social circle in which the individual has lived. In the other it is the overwhelming impulse of brutal selfishness and low passions. We always yield to an impulse which by reason of our previous mentality holds us in its power. We are all in bondage to our innate or acquired mentality. One has a fatal instability of disposition. Another is wholly unable to control his appetites. The alcoholic believes himself free, and will say, "I am free to drink or not to drink." The unfortunate fellow does not realize that he is the slave of the demands of his diseased body which cannot endure abstinence. We are all constantly restrained by internal barriers which suppress our freewill as much as a wall or a policeman would restrain our bodily liberty. Our wishes and decisions are all determined. When we follow our wants, we do not think of "free-will," but realize that we are then slaves to our tastes and appetites. It is when we obey intellectual motives and moral ideas that we pretend to be "free." And we call him a strong man who always bases his conduct on rational principles and philosophical convictions. But as a matter of fact, he also is determined. He simply has a clear consciousness of the way he wants to go. He finds attractions along certain roads where other people find none. His course is decided by a distinct idea of his end and aim. His head and heart are together. His ideas and his feelings agree. And his 
will drops passively into the path which sentiment and reason have worn for it. ${ }^{1}$

The causation of volitional phenomena runs back in an unending series. Indeed, will belongs to those forms of psychical causation, the connections of which we can most easily follow. Not only the immediate causes in the motives are apparent, but also the origin and diverse conditions of the individual and general social development. An intentional act, which takes place as the result of forethought and deliberation, we can retrace in circumstances extending back into the earliest history of the agent. We may, indeed, discover some of the elements in inherited qualities of the family or tribe. ${ }^{2}$

Can any one really believe that the will is unconditioned and out of causal connection with other elements of reality or that it was produced of itself? Must it not be said to be in relation with other things on which it depends, and by which it has been formed? "A man is a psycho-physical organism, with a certain body, a certain system of organs, certain impulses, certain sensibility, certain intelligence, and certain will. Was his beginning without cause, a result of his own free choice? Hardly; he was conceived and produced by parents, whom he resembles in body and in soul, inheriting their temperament, their desires, their sensuous-intellectual powers, as well as their bodily characteristics. He receives all the physichospiritual qualities of his ancestors, as his natural endowment. His sex, too, which exercises such a decisive influence upon his entire life, is determined, by

${ }^{2}$ Cf. Dubois, op. cit., pp. 50-57.

${ }^{2}$ Cf. Wundt, "Ethik," Bd. II, S. 82-86. 
what causes we do not know, yet no one will claim that it is the result of his own choice. Hence nothing in the origin of man indicates that he constitutes an exempt territory in the kingdom of nature, and is not subject to her laws. These innate predispositions or tendencies are then developed under the determining influences of environment, of natural and, above all, human environment. The child is educated by the family in the form of life peculiar to his people. He acquires their language, and with the language a more or less complete system of concepts and judgments. $\mathrm{He}$ is educated into the customs and practices of his country, by which the actions and judgments of most persons are governed during their entire lives. He is sent to school, and there obtains the general culture of the age; he is taken into the church, where he receives further training, which, positively or negatively, exercises a permanent influence upon his inner life. When at last he leaves the home and the school, it is only to be subjected to the influence of a new educative force,society. He belongs to a certain social class by descent and, as a rule, for life. Society works upon him incessantly, telling him in words and in deeds what is right or wrong, what is proper or improper, what is attractive or repulsive. It assigns to him his tasks, by example and by command. In all these ways his whole life, with all its activities, is determined. . . . There seems to be no break in the chain: nation and age, parents and teachers, environment and society, decide the predisposition and development, rank and life-problems, of each individual human being. $\mathrm{He}$ is the product of the 
collective body from which he springs. Just as the twig on a tree does not owe its form and function to its will, but to the whole body in which it grows, so a man does not exist prior to himself, as it were, and choose his will, his nature, and his lot in life by a decision of his will. He comes into the world and acts in the world as a member of the collective body. And as a part of this people his life forms a part of the total historical life of humanity, and, finally, of universal nature." 1

In view of such facts as these we may be led to agree with Spinoza that "The soul acts according to fixed laws, and is as it were an immaterial automaton." 2 "In the mind there is no absolute or free-will; but the mind is determined to wish this or that by a cause, which has also been determined by another cause, and this last by another cause, and so on to infinity." " "Most writers on the emotions and on human conduct seem to be treating rather of matters outside nature than of natural phenomena following nature's general laws. They appear to conceive man to be situated in nature as a kingdom within a kingdom: for they, believe that he disturbs rather than follows nature's order, that he has absolute control over his actions, and that he is determined solely by himself. . . . Nature's laws and ordinances, whereby all things come to pass and change from one form to another, are everywhere and always the same; so that there should be one and the same method of understanding the nature of all things whatsoever,

1 Paulsen, "System der Ethik," Bd. I, S. 448-450.

"Spinoza, "On the Improvement of the Understanding," p. 32.

'Spinoza, "Ethics," tr. Elwes, p. 119. 
namely, through nature's universal laws and rules. Thus the passions of hatred, anger, envy, and so on, considered in themselves, follow from this same necessity and efficacy of nature; they answer to certain definite causes, through which they are understood. ... I shall consider human actions and desires in exactly the same manner, as though I were concerned with lines, planes, and solids." " "An infant believes that of its own free will it desires milk, an angry child believes that it freely desires vengeance, a timid child believes that it freely desires to run away; further, a drunken man believes that he utters from the free decision of his mind words which, when he is sober, he would willingly have withheld: thus, too, a delirious man, a garrulous woman, a child, and others of like complexion, believe that they speak from the free decision of their mind, when they are in reality unable to restrain their impulse to talk. Experience teaches us no less clearly than reason, that men believe themselves to be free, simply because they are conscious of their actions, and unconscious of the causes whereby those actions are determined." 2

The formula used by determinists is this: The action of man constantly proceeds with necessity from two factors-his character and the motives which come from the environment. Each of these factors is under the guidance of causality and is strictly necessitated. The germ of the character is innate; its development is conditioned by the experiences of life. The motives that act on man are introduced with inevitableness by the absolutely fixed course of the world. Any action, then, is the necessary result

${ }^{1}$ Ibid., pp. 128, 129.

2 Ibid., p. 134. 
of a determinate character in contact with determinate circumstances. Let us notice somewhat minutely the way in which will is influenced. "The will of animal creatures may be said to be set in motion in two different ways: either by motivation or by instinct; thus from without or from within; by an external occasion, or by an internal tendency. ... But, more closely considered, the contrast between the two is not so sharp, indeed ultimately it runs back into a difference of degree. That is to say, the motive also only acts under the assumption of an inner tendency, $i$. e., a definite quality of will which is called its character. The motive in each case only gives to this a definite direction-individualizes it for the concrete case. So also instinct, although a definite tendency of the will, does not act, like a spring, wholly from within; but it, too, waits for some external circumstance necessarily demanded for its action, which at least determines the time of its manifestation; such is, for the migrating bird, the season of the year; for the bird that builds its nest, the fact of pregnancy and the presence of the material for the nest; for the bee it is, for the beginning of the structure, the basket or the hollow tree, and for the following work many individually appearing circumstances. ... It follows from this exposition that being determined by motives presupposes a certain breadth of the sphere of knowledge, and consequently a more fully developed intellect: therefore it is peculiar to the higher animals, quite pre-eminently, however, to man; while being determined by instinct demands only as much intellect as is necessary to apprehend the one quite specially determined 
motive, which alone and exclusively becomes the occasion for the manifestation of the instinct. On this account it is found in the case of an exceedingly limited sphere of knowledge, and consequently, as a rule, and in the highest degree, only in animals of the lower classes, especially insects. Since, accordingly, the actions of these animals require only an exceedingly simple and small motivation from without, the medium of this, thus the intellect or brain, is very slightly developed in them, and their outward actions are for the most part under the same guidance as the inner, that is, they follow upon mere stimuli as physiological functions of the ganglion system. This is, then, in their case, exceedingly developed. . . . According to all this, instinct and action through mere motivation, stand in a certain antagonism, in consequence of which the former has its maximum in insects, and the latter in man, and the actuation of other animals lies between the two in manifold gradations according as in each the cerebral or the ganglion system is preponderatingly developed." 1

One naturally asks, "If this is the real nature of will and volition, where is the difference between man's will and the will of an animal?" The reply is that animals are moved to action by the impulses and perceptions of the moment. The sight of the prey or of the foe immediately produces appropriate movements of pursuit or flight. Even the most highly developed animals possess but the rudiments of hesitation, deliberation, and choice, which processes are characteristic of man. He decides on

${ }^{1}$ Schopenhauer, "Die Welt als Wille und Vorstellung," Bd. II, S. 390 ff. 
his conduct after comparing various possible courses of action with the ultimate aims of his individual and social life. He is not determined by impulses, but by ideas of ends. He views his entire life as a unity, and chooses his particular acts according to their relation thereto. Animal life is made up of more or less isolated or disconnected functions; while human life is a self-conscious unity which determines the individual moments as demanded by the purpose of the whole. Each impelling thought, as it presents itself, is subordinated to the larger conception of life's total meaning and purpose. For action of the reflex type there is substituted action which is the result of deliberate choice. Instead of the coercive guidance of the immediate idea, there is the conduct that comes from a reflective consideration of the comparative claims of the many ideas which appear on the field of consciousness and contend for the mastery. Man can ponder the various courses to which he is enticed; he can compare and criticise the results of following each competing impulse; he can study the entire situation; he can contrast the conceived future with his present and his past; he can test it by the touchstone of his prevailing aspirations, his dominant aims in life, his permanent and larger and deeper self. He can shape his life in accordance with a single central purpose which governs its every act. Thus man need not be, like the animal, simply the creature of impulse, even of that organized impulse which we call instinct. He need not live merely in the immediate present and in the immediate future. He is independent of what is directly present in space and time, the sense impressions of the moment. He carries 
around in his head abstract ideas and universal notions, which give to his action the character of deliberate reflection and purposiveness, and lay the basis for language, remembrance of the past, foresight of the future, co-operation with other men in politics, science, and art. He can "look before and after," can forecast remote as well as near events, and can act under the guidance of a far-reaching survey of his life. ${ }^{1}$

This is all there is of man's so-called freedom. He differs from the beast, not in having the power of free-will, the exercise of undetermined choice, but in having a more highly developed consciousness. He can grasp a greater number of facts at once, can keep them before his deliberation for a longer time, can form abstract ideas and can reason about them, can remember past experiences better, can organize his experiences into a self-conscious whole, can calculate the probable lines of sequence farther, and can act with purposive foresight. In short, his reason is more discursive. But at the time of action, he does, and can do, only one thing; namely, that which seems to him at the moment best, in the light which he then has. Such expressions as "I could have decided otherwise if I had wanted to," are utterly meaningless. It is this "wanting to" that is in question. Of course you could have chosen some other course if you had so desired. But the point is that with your precise nature in that exact condition of things there was but one desire possible. Before you could have decided differently, your character or the circumstances would have had to be different. In short,

${ }^{3}$ Cf. Paulsen, op. cit., Bd. I, S. 460, 461; Seth, op. cit., pp. 44-46; Schopenhauer, "Ueber die Freiheit des Willens," S. 33-36. 
other antecedents must have been present than those which existed.

Man's so-called growth in freedom is really but development of wisdom in judging. A man gains greater skill in canvassing all the motives to action. His power of discernment enlarges. He can look farther into the future, can hold more alternatives before his mind at once, and can estimate more correctly their lines of sequence. Instead of calling it the faculty to choose more wisely, we could just as well call it the ability to see and understand more clearly, the power of more discursive reason. At the moment when a man must make up his mind, however, he always decides as it seems best to him at the time.

In agreement with these views, whenever we wish to influence the acting of another person we always try to do it by changing his knowledge. The intellect is the medium through which motives affect the character, which is the real kernel of man. Only so far as understanding correctly accomplishes its function of presenting to the inner self the inducements in their true nature, that is, as they are in the actual world, can the man decide in accordance with his real nature, and express himself without interference. In this case man is intellectually free, that is to say, his action is the pure result of a reaction of his character upon motives which are in agreement with the facts of the world. The ability to direct his behavior by means of his intelligence is the only "freedom" that a man has. The fact that his conduct varies with and conforms to his judgment indicates that he controls his own actions. 
The fact that man is moved by abstract thoughts instead of by sense-perceptions does not imply a breach in the law of causation. Thoughts are motives, the same as are perceptions; and all motives are causes, entailing necessity. Man can consider, can reflect, can deliberate; and is in so far "free" from coercion by the immediate perception; but determination by considerations, reflections, and deliberations is no less strict and inevitable than determination by perceptions. Whether an object is pulled by a heavy rope or by a fine wire does not alter the stringency of the causation. Whether a message is sent to its destination directly, or passes through many relay stations, makes no difference in the absolute relation of cause and effect. Whether the message is transmitted by horse, by railroad, by telephone, or by wireless telegraphy, the effect is absolutely dependent upon its causes. Similarly, although the modes of motivation are different in the cases of man and animal, the necessity and inevitableness of causal dependence are precisely the same in both. An abstract thought is a causal determinant of the will no less than is an immediate sense-perception; and ultimately the abstract thought runs back to some external impression or sensation. The connection is simply long-drawn-out or broken up into many subdivisions. Instead of the effect being joined to the cause at close range both in space and time, it is bound to it at great distance and over a long period of time, and through the mediation of conceptions and thoughts in a long chain. This is because of the constitution of the organ of thought, the brain or consciousness, which permits influences to be taken 
up and carried through complicated stages and détours. But all this does not in the least impair causality and the inevitable dependence of effects on causes.

A question naturally arises concerning the difference between the normal man, who is commonly regarded as a responsible agent, and the abnormal man, the lunatic, the somnambulist, or the hypnotized person. The volitions and actions of both are determined. What discrimination can be made in the kinds of determination? In the case of the normal person, there is self-control. He is conscious of the various motives to action; and the victory of one is obtained only after due competition with the others. In the case of the abnormal person, however, there is defective self-control, in which motives do not attain full development either because consciousness is temporarily impeded or because it is permanently incapable of motivation. For example, even though a somnambulist or a hypnotized person may follow motives, he differs from the normal man in that only one motive is present in consciousness and acts compellingly because other motives are not there to counteract it. His action cannot be called deliberate and voluntary. Even though a lunatic may balance motives against each other and act with thoughtful deliberation, he nevertheless differs from the normal man in not having a developed, reflective selfconsciousness. He has not the normal consciousness of his own individuality, with its previous experiences co-ordinated into a unitary self. And he acts not with the normal consciousness of the significance which his acts have for his own purposes and 
character. His behavior is not expressive of an integrated personality. Such as these are the only differences between the acts of the abnormal person and those of the normal person. It is improper to claim that in the one case they are determined while in the other they are not. "Freedom" in this sense exists in neither instance. Efficient causes determine the volitions and acts of both the normal and the abnormal; but in the case of the abnormal the causation is not of the highest psychical order, development, or refinement.

Mill's refutation of some of the current objections to the doctrine of mental causation is well worth sketching. A free-willist asks, "Are there no such things as wilfulness, caprice, and obstinacy among men?" The determinist answers, "These things which you mention are themselves tendencies, fatal tendencies, to act or not to act. They cannot be used to show man's freedom from determination by motives." The free-willist further protests, "A determination of the will is made by the man and not by the motive." The determinist replies, "The man was induced by some motive to that determination. His specific volition was not without a cause. Suppose the sum of influences (incitements and inclinations) to volition A equal to 12 , and the sum of influences to counter volition $B$ equal to 8 ,- - can we conceive that the determination of volition $\mathrm{A}$ should not be necessary? He can only conceive the volition $B$ to take place by supposing that the man creates (calls from non-existence into existence) a certain supplement of influences. But this creation is inconceivable. Yet were it not so, we should still have 
to suppose some cause by which the man is determined to it. We can never escape necessity. If he is led to prefer innocence to the satisfaction of a particular desire, through an estimate of the relative worth of the two, can this estimate, while unchanged, leave him at liberty to choose the gratification in preference to innocence?" The free-willist objects further, "You say that the will is governed by the strongest motive; but I only know the strength of motives in relation to the will by the test of ultimate prevalence; so that this means no more than that the prevailing motive prevails." The determinist replies: "There are two flaws in this argument. First, those who say that the will obeys the strongest motive, do not mean the motive which is strongest in relation to the will, or in other words, that the will follows what it does follow. They mean the motive which is strongest in relation to pain and pleasure; since a motive, being a desire or aversion, is proportional to the pleasantness, as conceived by us, of the thing desired, or the painfulness of the thing shunned. And when what was at first a direct impulse toward pleasure, or recoil from pain, has passed into a habit or a fixed purpose, then the strength of the motive means the completeness and promptitude of the association which has been formed between an idea and an outward act. This is the first answer. The second is, that even supposing there were no test of the strength of motives but their effect on the will, the proposition that the will follows the strongest motive would not be identical and unmeaning. We say, without absurdity, that if two weights are placed in opposite scales, the heavier will lift the other up; 
yet we mean nothing by the heavier, except the weight which will lift up the other. The proposition, nevertheless, is not unmeaning, for it signifies that in many or most cases there is a heavier, and that this is always the same one, not one or the other indifferently. In like manner, even if the strongest motive meant only the one which prevails, yet if there is a prevailing one-if, all other antecedents being the same, the motive which prevails to-day will prevail to-morrow and every subsequent day, the free-will theory is lost." 1

Mill's conception of the nature of motives needs to be completed and strengthened by the developments of physiological psychology. Some of the elements that enter into, and add their strength to, the motive that determines action may be below the threshold of consciousness. We know only partially the multitude of factors of which volition and action are the results. We are not aware of the force of each constituent element, the degree of its intensity, the part it plays in the origin of the act. Many of the factors are purely physiological, and lead to reflex movements without passing through consciousness. The field of the unconscious is greater and more important than that of the conscious. In consciousness there appear only a few of the manifestations-sensations, feelings, ideas - of the cerebral activity which determines action. In every psychical process some of the links escape us. The greater part of the phenomena take place without our being aware of them. Stimuli of which we have no knowledge may act as excitants upon centres of cerebral activity without ${ }^{2} C f$. Mill, op. cit., pp. 574-578; 604, 605. 
our knowing it. These centres then influence action, and thus become the unknown point of departure for movements of which we may or may not become conscious. In view of our ignorance of the subtle physiological processes which influence action without appearing in consciousness, there can be absolutely no proof that volition and action arise "freely," that is, without causal dependence upon antecedent mental and physiological phenomena.

The free-willist, as we saw in the quotations from James and others, claims the possibility of dual choices, that is, that in the moment of choice, it may fall out in any one of different ways. Now, the determinist attempts to prove that this claim is an absurdity. The hypothesis rests on an imagined experiment. "Suppose, it is said that a moral agent is set back for a second time into the critical moment of choice,-say, e. g., that Eve is placed again in Paradise and given another chance,-in that case, even if the circumstances are exactly repeated, it will be possible for her to resist the temptation, instead of yielding to it. Not, I submit, if we are thorough with the experiment. Do but really repeat the circumstances; make it the same day and hour, the same scene and the same tempter. Above all, let it be the same Eve. Let just those innate proclivities which operated before operate again; let them be played upon by solicitations which exactly repeat the previous ones, - the same in number and hue, the same in intensity and power and degree of prevalence,and the action will be the same, inevitably. Inevitably, because by the time the 'circumstances,' outward and inward, are fully repeated, the act is 
already done. That the issue should be different in the two instances is unthinkable. It splits itself on an impossibility, the impossibility of drawing any line between the mind and the act which comes out of it. The nature of mind does not permit of such a thing. Mind is what it does, and is nothing else. The being and the doing are inseparable. To do a different thing is to be so far a different person. To say with Professor James, that the ego which elected to follow one path could, under an exact repetition of the situation, choose to follow another, means that the same ego could be two different beings at once. Freedom which depends on this is not merely contradictory to the faith of Science; it is incompatible with the very conditions of thought. The ordinary man's assertion, then, that in the same circumstances he 'could have done other than he did' crumbles away when we try to think it." ${ }^{1}$

Acts could not have been done by a man in any manner or in any order other than that which has in fact obtained. All the deeds of a man necessarily follow from his character, and by that character are conditioned to exist in a particular way. If they could have been different, his personality would also have had to be able to be other than it was. Before different behavior could have become real, his diverse nature would have had to be real; or, in other words, he would have had to have two or more distinct natures. The statement "He could have acted otherwise" means really "He could have

iScott, "Post-Kantian Idealism and the Question of Moral Responsibility," in International Journal of Ethics, April, 1910, pp. $331,332$. 
been different from what he was." This is because man's will is his real self, the kernel of his being. $\mathrm{He}$ is what he wills to be, and wills to be what he is. To ask him whether he could have willed otherwise than he willed, is to ask him whether he could have been another person than himself.

"In accordance with the absolutely universal validity of the law of causality, the conduct or the action of all existences in this world is always strictly necessitated by the causes which in each case call it forth. It makes no difference whether such an action has been occasioned by causes in the strictest sense of the word, or by stimuli, or finally by motives, for these differences refer only to the grade of the susceptibility of the different kinds of existences. The law of causality knows no exception; but everything from the movement of a mote in a sunbeam to the most carefully deliberated action of man, is subject to it with equal strictness. Therefore, in the whole course of the world, neither could a mote in a sunbeam describe any other line in its flight than it has described, nor a man act any other way than he has acted; and no truth is more certain than this, that all that happens, be it small or great, happens with absolute necessity. Consequently, at every given moment of time, the whole condition of all things is firmly and precisely determined by the condition which has just preceded it, and so it is with the stream of time back to infinity and on to infinity." 1

'Schopenhauer, "Die Welt als Wille und Vorstellung," Bd. II, S. $362 f f$. 


\section{CHAPTER IX}

\section{CONCEPTION OF FREEDOM SYNONYMOUS WITH IGNORANCE OF CAUSES}

When I pick up my pencil, no one can predict with absolute certainty what I shall do with it. What follows is to all appearances a new event quite independent of any which preceded it. Whatever I do with it, a sequence of acts seems to start in my present volition. No other person can positively foretell what I shall do, for the contents of my mind are not objectively perceived by any one. Nevertheless, if the processes that take place in the mind could be observed, they would be found to be routine changes as much as any in the physical world. In other words, a present exercise of will is not a first cause, but is merely an intermediate link in a chain of events following each other in a regular way.

As a rule, our ability to retrace a series of events terminates when we get back to the mind of the person who was the actor. We cannot track with certainty the successive mental steps that led to the particular decision. But this does not justify us in concluding that there was no regular succession of psychical occurrences, or that the choice did not follow as the necessary product of a special disposition, which was in turn the result of certain ideas, purposes, desires, passions; while these were the outcome of determinate education, experiences, inherit- 
ance; and these were connected with race, class, climate, and so on. Individual acts of will are to be regarded as secondary causes in a long chain of sequent events, as stages in a regular succession of occurrences. Will is thus not a primary and arbitrary cause.

Every act is the necessary product of two factors, - the inner tendency or force which here expresses itself, and the particular environmental occasion which calls forth that expression. Consequently, every act could be definitely calculated and predicted, if character and environment could be thoroughly known,- - if, on the one hand, all the forces of the circumstances could be measured, and if, on the other hand, all the subtle influences of disposition, the various tendencies and counter-tendencies to action, both those that lie in consciousness and those that lie beneath the threshold of consciousness, could be discovered. But such thorough knowledge is impossible. Character is the total result of all past experiences, and is undergoing continual modification in current experiences. We could not have a precise knowledge of it unless we could trace back and estimate all the diverse influences both of inherited tendencies and of individual education. The ends and purposes which a man unalterably seeks are necessarily fixed by his nature; the means or instruments which he uses in this search are inevitably determined by external conditions and by his conception of them, which depends on his intelligence and education. As the unavoidable effect of all these determining causes there follow his every act and the entire rôle which he plays in the world. We should 
recognize that our inability to prophesy behavior results from our being unaware of the past causes which have formed the character and of the present forces now influencing it. This explanation is more satisfactory than recourse to the mysterious freedom of will.

Spinoza declared that our ascription of "freedom" to persons was due to unconsciousness of the determining causes. "Men think themselves free inasmuch as they are conscious of their volitions and desires, and never even dream, in their ignorance, of the causes which have disposed them so to wish and desire. . . . Their idea of freedom, therefore, is simply their ignorance of any cause for their actions. As for their saying that human actions depend on the will, this is a mere phrase without any idea to correspond thereto. What the will is, and how it moves the body, they none of them know. . . . A thing is called necessary either in respect to its essence or in respect to its cause; for the existence of a thing necessarily follows, either from its essence and definition, or from a given efficient cause. For similar reasons a thing is said to be impossible; namely, inasmuch as its essence or definition involves a contradiction, or because no external cause is granted, which is conditioned to produce such an effect; but a thing can in no respect be called contingent, save in relation to the imperfection of our knowledge. A thing of which we do not know whether the essence does or does not involve a contradiction, or of which, knowing that it does not involve a contradiction, we are still in doubt concerning the existence, because the order of causes escapes us, - such a thing, I say, 
cannot appear to us either necessary or impossible. Wherefore we call it contingent or possible." ${ }^{1}$

The uninstructed take things according to their first appearance, and attribute the uncertainty of events to a "freedom" in the agents which involves capriciousness in action. The instructed, however, have learned that there are very many principles in nature which are hidden from ready perception, and that contrariety of events may proceed, not from caprice in the cause, but from the unperceived operation of contrary causes. Thus, for instance, the physician when the usual symptoms of health or sickness disappoint his expectations, and medicines do not operate with their usual effects, is not greatly surprised at the matter, and is never tempted to deny, in general, the uniformity and necessity of those principles by which the human body is regulated. $\mathrm{He}$ knows that the physical organism is very complex and contains many forces beyond easy discovery, and that it must often appear uncertain in its operations. He therefore does not regard any irregular events as proof that the laws of nature are not observed therein. In like manner, the moral philosopher must apply the same reasoning to the actions and volitions of the mind. The most unexpected resolutions and behavior may be accounted for when the particular circumstances of character and situation are discovered. A person of affable disposition gives a peevish answer: the disturbing cause is found in a tooth-ache or a bad dinner. A sluggish fellow is seen in rapid gait: he has just heard news of sudden good fortune. Thus seeming irregularities do not ${ }^{2}$ Spinoza, op. cit., pp. 71, 75, 108. 
really indicate breaches in the uniform observance of law. ${ }^{1}$

The determinist maintains that occurrences in the psychical world take place according to natural laws and with the same necessity as occurrences in the physical world. The reason that they cannot be accurately calculated and foretold is simply owing to their great complexity. The same holds true of many processes in the physical world, for example, in the physiological determination of sex in the fetus. A perfect intellect, one that comprehended all the antecedent facts, would understand the volitions and actions of men as perfectly as the movements of the planets.

When the free-willist calls attention to the fact that the calculations of statesmen, economists, and financiers are always attended with great uncertainty, we must not let him force the conclusion that this doubtfulness is due to free-will; we must attribute the cause to its real source, namely, insufficient knowledge of the influences in operation. A similar ignorance of the causes at work entails the same uncertainty concerning the physical phenomena of wind, clouds, rain, hail, and storms; but this vagueness does not lead us to regard these things as the results either of chance or freedom. As a matter of fact, prevision here is no more accurate than in the domain of economics. The coming of a cyclone cannot be foretold as long in advance as the coming of a commercial crisis. The varying depth of water in a river and the changing rate of the current cannot be predicted with as much certainty as the trips of the rail-

$$
{ }^{2} C f \text {. Hume, op. cit., pp. 89-91. }
$$


road trains along the banks of the stream, although the waters are regulated by the forces of nature while the trains are directed by men. If man should ever become infinitely wise, his prevision of economic events would be as certain as his forecast of astronomical changes. ${ }^{1}$

${ }^{1}$ G. Gide, "Principles of Political Economy," pp. 5-8. 


\section{CHAPTER $\mathrm{X}$}

\section{DETERMINISM ASSUMED IN DAILY LIFE AND IN SCIENTIFIC PROCEDURE}

Is all our relations with others in daily life we are obliged to assume that individual acts of will fit in with and are determined by a larger whole. We simply cannot believe that a particular nature under certain conditions will respond to a definite stimulus sometimes one way, sometimes other ways. We are forced to count on uniform conduct; and if any unexpected behavior takes place, we look for the cause that produced the alteration,- some unusual experience, some sickness, some temporary indisposition, some reverse of fortune. We always assume regularity, and never suppose uncaused or unmotived variations. $^{1}$

Men are so dependent upon one another that scarcely any action of any man is entirely complete in itself. Hardly any operation takes place without some reference to the operations of others, which are requisite before the intention of the agent is fully realized. The poorest farm laborer looks for the protection of the authorities to render secure the fruits of his labor. He expects that when he takes his product to town to sell, he will find purchasers. He counts on being able to obtain from others certain commodities which he needs and is able to pay for. In the ${ }^{1}$ Cf. Paulsen, op. cit., Bd. I, S. 448. 
dealings of commercial life, where intercourse is so extensive and complicated, each man relies on the co-operation of a great many other men, firmly believing that these "voluntary agents" are going to continue in their behavior the same as he has always found them. The manufacturer employs the services of many very different men and women, but he counts upon, and places his dependence upon, that labor in the same way as upon the labor of the machinery. The thoroughness with which, in our thoughts and expectations, we link the operations of human beings with the action of natural forces is well illustrated in the case of a prisoner. A prisoner is convinced of the impossibility of escape as well by the obstinate moral nature of the jailer as by the material strength of the walls and bars. Indeed, in an attempt at freedom, he prefers to work upon the stone and iron. If sentenced to die, he foresees the certainty of his death as much in the constancy and fidelity of the officials as in the mechanical action of the gallows or electric chair. His mind feels no difference in passing from the operations of the human voluntary agents to the operations of the mechanical agents. He is no less positive of the future event than if the whole series of incidents leading up to it were cemented together by what we call physical necessity. In many instances we can be as confident of the acts of human beings as of the action of natural forces. We may feel as sure that a man will not put his hand into the fire and hold it there until it be consumed as that if he jumped out of the window and met no support he would not remain suspended in the air. A man who dropped a roll of money on a 
crowded thoroughfare would as soon expect it to rise and fly away like a balloon as to count on its remaining there. If no uniformity in human actions existed, and if every event were irregular and anomalous, it would be impossible to make generalizations concerning human nature; and experience and reflection could never be of any service. ${ }^{2}$

Scientific procedure is equally dependent upon belief in determinism. Without this belief there would be possible no psychology and no mental science whatever. To give it up would be to offend against that law of reason according to which we always posit a cause for the caused, and regard this in turn as produced by some antecedent cause. ${ }^{2}$

There is no part of learning to which determinism is not essential. History would be an impossible science if we could not depend on the veracity of the historians. Political science could not exist if laws and forms of government had not a uniform influence upon society. Moral science would be out of the question if particular characters did not react upon stimuli in certain definite ways. Literary criticism would be vain if the sentiments and conduct of the actors could not be declared either natural or unnatural in such individuals under such conditions. All science acknowledges the doctrine of necessity and the legitimacy of inference from character and circumstances to conduct.

In short, science means simply and only associating an event with its causes, assigning it to the series and general collection of previous occurrences which

${ }^{1}$ Cf. Hume, op. cit., pp. 87-95.

${ }^{2}$ Cf. Wundt, op. cit., Bd. II, S. 82. 
have produced it and made it necessary. To give a scientific explanation of a fact is to place it where it implicitly belongs among others in virtue of which it could neither not exist nor be otherwise than it is. Determinism is thus the fundamental axiom of all science. Science ends where liberty begins. ${ }^{1}$

When we name any branch of human knowledge a science, we do not mean to bestow on it simply an honorary title. We mean that "its facts are connected by certain necessary relations which have been discovered, and which are called laws." Such, for example, is the science of astronomy, where the regularity of occurrences is so obvious as to attract the attention even of persons not at all accustomed to scientific speculation. The periodicity of the movements of the stars is one of the oldest discoveries of science. The detection of uniformity in the changes that take place in inorganic matter and in organic bodies was more difficult, and took many centuries longer. But now the sciences of physics, chemistry, and biology are well established. The laws which govern currents of air and water have also been ascertained, and form the basis of the science of meteorology. Little by little the idea of law, of a permanent regularity of phenomena, has penetrated all domains of human knowledge, even those which once seemed destined to remain forever closed to it. ${ }^{2}$

The idea that there is room in the universe for active forces over which the laws of the natural order have no dominion, has been compelled again and

'Cf. Flournoy, "Métaphysique et psychologie," quoted by DuBois, op. cit., p. 48.

${ }^{2}$ Cf. Gide, op. cit., pp. 3-4. 
again to yield to the view that these laws admit of no exceptions. The last point where independence of the natural order is claimed to exist is in the conscious will of man. But by taking sufficient account of his physical nature, nurture, and environment, it seems possible to reduce even man's will to a mere manifestation of natural forces. Man's so-called free spirit is but nature's own power flowing through a marvellously complex channel. The natural laws become here infinitely subtle and difficult to trace; but there is no evidence to prove that they are broken. $^{1}$

From the scientific point of view, man must regard himself as part of the totality of things, animals, and persons. Human nature is a portion of universal nature; man's life participates in the wider life of the universe. The natural order can admit of no real exceptions; what seems anomalous must cease to appear so in the light of advancing knowledge. Science is constantly verifying this truth. Accordingly when science attacks the problems of human life, it immediately breaks down man's imagined independence of nature, and demonstrates his entire dependence. The forces which bind him are primarily the inner forces of motive and disposition and established character, yet between these inner and outer forces of nature there is no real break. They are ultimately one. Man gets his original endowment by heredity; this is developed and formed into character by the influence of circumstances and education. All that he does is to react - as any animal or plant or even stone does in its measure - on the influences

${ }^{3} C f$. Scott, op. cit., p. 334. 
which act upon him. Such action and reaction together yield the whole series of occurrences which constitute his life. The admission of freedom would be fatally embarrassing to scientific procedure. Science is bound up with the denial of freedom in any and every sense of the word. ${ }^{1}$

Thus, the great idea of a natural order, after having step by step successfully invaded all other fields of knowledge, has at last penetrated the domain of man and society.

In this connection, we ought to mention the argument from statistics. Statistics have demonstrated many times the almost infallible regularity with which are produced both the most important facts of life (such, for example, as marriages) and also the least significant (such as putting unaddressed letters in the mail). ${ }^{2}$

There is a striking agreement in the number of particular crimes committed each year. If any one will but notice the tables of comparative statistics, he will be fairly startled at the uniformity shown from year to year. For example, the number of murders and homicides in the United States for each million of people was, for the successive years from 1900 to $1906: 108.4,100.9,111.7,112.4,104.4,111.9$, $108.9 .^{3}$

In discussing the statistics of crime, Mayo-Smith ${ }^{4}$ calls attention to some impressive regularities. In southern climates, crimes against the person are

${ }^{2} C f$. Seth, op. cit., pp. 362-364.

${ }^{2} C f$. Gide, "Traité d'économie politique," 9 th edition, p. 8. 336.

${ }^{3}$ Bliss, "New Encyclopedia of Social Reform" (1908), pp. 334-

"Mayo-Smith, "Statistics and Sociology," pp. 270-279. 
more numerous than those against property, while in northern latitudes the offences against property are in the excess. There are more crimes against the person in summer than in winter, while wrongs against property are fewer in summer than in winter. The influence of temperature is clearly seen in the fluctuations in the number of suicides. In general, and for all countries, the number of suicides increases steadily from the beginning of the year until it reaches the maximum in June, and then decreases until it reaches the minimum in December. ${ }^{1}$ The discovery of the astonishing uniformity in the criminal statistics of France led Quetelet to write his of t-quoted sentence, "There is a budget which is paid with greater regularity than that of any finance minister,-it is the budget of the prison, the galleys, and the scaffold."

It thus appears possible to foretell with marvellous precision the number of particular crimes which will be produced in a given population if it is not subjected to unusual variations in temperature, supply of food, and industrial composition. Crime seems to be the consequence of certain great natural conditions over which the individual has little or no control.

That man's actions are determined is in this way attested by the results of statistical science. The observation of men acting in numbers sufficiently large to neutralize the influences which operate only on a few, and to leave the total product about the same as if the volitions of each had been affected by the determining causes common to the whole, shows 
the results so uniform that they may be as accurately foretold as any physical effect which depends upon a multiplicity of causes. The cases in which volitions do not admit of being confidently predicted, are those in which our knowledge of the influences at work is so incomplete that with equally imperfect data there would be the same uncertainty in the forecasts of the astronomer and the chemist. ${ }^{1}$

${ }^{2}$ Cf. Mill, op. cit., p. 577. 


\section{CHAPTER XI}

CONCERNING “THE TESTIMONY OF SELFCONSCIOUSNESS "

IT is often asserted that man is immediately conscious of having freedom of will. Sidgwick, for example, says: ${ }^{6}$ "I hold, therefore, that against the formidable array of cumulative evidence offered for Determinism, there is to be set the immediate affirmation of consciousness in the moment of deliberate action." "We must examine this alleged testimony of self-consciousness.

Before cross-examining this internal witness in order to discover exactly what it declares, we may call attention to the fact that even if we had a consciousness of being able to determine ourselves in despite of all causes, this would not prove the real existence of that ability. We have a consciousness that the sun travels from east to west around the earth. But we should be greatly in error to conclude that therefore the sun actually does this. For a long time, of course, men believed that their consciousness of this phenomenon demonstrated its existence. But science now knows certainly that it is not true. In many other matters, consciousness is deceptive, and does not demonstrate the reality of its perceptions. The hallucinated person has a clear and precise consciousness of things which are ${ }^{2}$ Sidgwick, "Methods of Ethics," p. 65. 
unrealities. For example, he may be told that Mr. Smith is Mrs. Jones; whereupon in Mr. Smith he perceives Mrs. Jones, and acts toward him as he would act toward her. He thinks that he is with her. He has a consciousness of seeing, hearing, and touching Mrs. Jones, when in reality he sees, hears, and touches Mr. Smith. His consciousness deceives him. After being brought out of his hypnotized state he executes an absurd order given to him while hypnotized; but nevertheless thinks himself free, claims to have a consciousness of his freedom, and tries to find pretexts to justify his absurd action. Thus the facts of hypnotism furnish experimental proof of the insufficiency of the argument from the testimony of self-consciousness. ${ }^{3}$

The advocates of indeterminism appeal to this inner oracle, and affirm: "Self-consciousness knows nothing of necessity or determinism. Every one has an immediate feeling of certainty that his acts have not been moulded by outside causes, that everything would have happened otherwise if he had willed differently. And he is likewise absolutely sure that his future actions depend upon his will. He could give up his present business and start another; he could emigrate to a foreign country; he could completely alter his mode of life and his behavior to others. Is the consciousness of such freedom but an illusion? This witness of the indeterminist needs to be cross-examined quite carefully, in order to discover the full truth. What does a man's selfconsciousness really testify?" This; that to the ex-

'Cf. Hamon, "Déterminisme et responsabilite," pp. 8-10; Tarde, "Philosophie pénale," p. 192. 
ternal influences which determine his life and character, must be added his own wishes and inclinations, convictions and resolutions. It tells him that he is not moved from without like a cogwheel in a machine, but through the mediation of an inner element-his will. His action is determined, not externally and mechanically, but by an internal force. His character is not moulded mechanically by things and men, but is formed by the reaction of an interior principle upon extraneous influences, by which process his nature is gradually developed. That is what his self-consciousness reports. Never, however, does it declare that the particular processes arise without cause, that at any moment of his life just any sort of occurrence may take place, utterly regardless of all preceding ones. Such lawlessness would be equivalent to a complete break-up of life into a series of disconnected and irrational accidents. Nor does his self-consciousness say that his character is itself absolutely uncaused, that it enters the world as a completely isolated element. In no sense does it contradict the view that the spiritual personality, like the organized body, is the product of evolution; that it originally sprang from something else; that it was exceedingly plastic during the earlier period of its development, but gradually became more capable of resistance, and acquired the ability to change its relations to its surroundings through its own decisions. ${ }^{1}$

Consciousness may tell us that we act without compulsion, but it never says that we act without cause, or that the forces which determine us are independent of our original disposition and experiences.

${ }^{2} C f$. Paulsen, op. cit., Bd. I, S. 450-451. 
It declares very explicitly that we do what we will. Now since we can think of contrary actions and regard either as possible if we will it, we may erroneously conclude that we have an ability to will either the one or the other of the contraries indifferently. But this is by no means implied in the testimony of self-consciousness. What we are immediately aware of is simply this, that if we will the one of the two contrary actions we can do it, or if we will the other we can do it. But whether we can will the one as well as the other is not included in the declaration of self-consciousness. This testimony does not in the least contradict the mature reflection: We can do what we will, but at any given moment we can will only a determinate object and absolutely nothing but that. "I can do what I will. I can, if I will, give all that I have to the poor and thereby become myself one of the poor, - if I will." But I cannot will it, because the opposing motives have a great deal too much power over me to permit me to will it. On the other hand, if I had another character, the nature of a saint, then I should be able to will it, indeed I could not help willing it, and I should have to beggar myself. Man always does what he wills; he does it nevertheless necessarily. This is because he is what he wills; for out of that which he is there follows necessarily all that he ever does. When action is regarded objectively, that is, from without, it is recognized to be subject to the law of causation in the same absolutely unfailing way that any other natural event is subject to it. But when regarded subjectively, man feels that he does only what he wills to do. This testifies, however, simply that his works are 
the manifestation of his own proper nature. The same would be felt by every being in the world, even the lowest, if it could feel. ${ }^{1}$

The indeterminist claims to be conscious of "freewill," conscious, before he decides, of being able to choose either way. The determinist takes exception to the use of the word consciousness with such an application. "Consciousness" discloses only what we do or feel, never what we are able to do. It is not prophetic. We are not conscious of what will or can be. "We never know that we are able to do a thing, except from having done it, or something equal and similar to it. We should not know that we were capable of action at all, if we had never acted. ... We should not feel able to walk if we had never walked. ... Having acted, we know, as far as that experience reaches, how we are able to act. . . . I am told, that whether I decide to do or to abstain, I feel that I could have decided the other way. I ask my consciousness what I do feel, and I find, indeed, that I feel (or am convinced) that I could, and even should, have chosen the other course if I had preferred it, that is, if I had liked it better; but not that I could have chosen one course while I preferred the other. When I say preferred, I of course include with the thing itself, all that accompanies it. . . It is . . unprecise . . . to say that I act in opposition to my preference; that I do one thing when I would rather do another; that my conscience prevails over my desires - as if conscience were not itself a desire - the desire to do

${ }^{2} \mathrm{Cf}$. Schopenhauer, "Ueber die Freiheit des Willens," S. 23-24, 43, 98. 
right. Take any alternative: say to murder or not to murder. I am told, that if I elect to murder, I am conscious that I could have elected to abstain: but am I conscious that I could have abstained if my aversion to the crime, and my dread of its consequences, had been weaker than the temptation? If I elect to abstain: in what sense am I conscious that I could have elected to commit the crime? Only if I had desired to commit it with a desire stronger than my horror of murder; not with one less strong. When we think of ourselves hypothetically as having acted otherwise than we did, we always suppose a difference in the antecedents: we picture ourselves as having known something that we did not know, or not known something that we did know; which is a difference in the external inducements; or as having desired something, or disliked something, more or less than we did; which is a difference in the internal inducements. ... I therefore dispute altogether that we are conscious of being able to act in opposition to the strongest present desire or aversion. The difference between a bad and a good man is not that the latter acts in opposition to his strongest desires; it is that his desire to do right, and his aversion to doing wrong, are strong enough to overcome, and in the case of perfect virtue, to silence, any other desire or aversion which may conflict with them." 1

A consciousness of being able to act in the presence of motives, but not under their control and determination, is not verifiable in experience. To verify it and see it in action we should have to be able to do

${ }^{1}$ Mill, op. cit., pp. 580-585. Cf. Priestley, op. cit., p. 90. 
two contrary things at the same time, or at different instants when all the conditions were identical. But this absolute equality and identity of circumstances and motives cannot be realized. When any one begins again to act in order to prove that he can do otherwise than he did before, this desire of showing that ability is, itself, a new element of determination for the second action and sufficient to account for it. ${ }^{1}$

Can I have a consciousness of my independence of every extraneous cause? For that I should have to know all the influences which act upon me - physical and social environment, temperament, heredity, habits, momentary impulses, etc. I should have to measure the power of all these forces, and should have to be able to show a remainder unaccounted for by them, and consequently attributable to myself alone. Now how could I have a consciousness of all - the external causes and their strength? This would not be consciousness properly so-called, but science or even exhaustive knowledge or omniscience. In other words, I should have to be able to solve this problem: Being given all the motions and all the forces of the universe, to calculate their action and to prove that my act, - for example, a perjury or a truthful testimony, - could not result from their action. Only an absolute intellect could accomplish such a task. The free-willist, however, appeals simply to "the consciousness which the will has of itself." Well, if I regard merely my own consciousness, I can only say, "I am not conscious of extraneous ${ }^{2} C f$. Fouillée, "Critique des systèmes de morale contemporains," p. 289. 
causes producing my act." The free-willist, however, translates this proposition into the following, which is widely different: "I am conscious that there are no extraneous causes producing my act." The confusion is evident. From the fact that a consciousness in me of alien causes does not exist, it does not at all follow that the causes themselves do not exist. It is as if I said, "I do not see the stars that compose the nebula; therefore, I see that stars do not compose the nebula." An astronomer may place me before a very powerful telescope and resolve the nebula into distinct stars. In the case of actions, I have no right to pass suddenly from the subjective to the objective, from the absence of any knowledge of extraneous causes to the negation of their existence. In a word, I cannot prove by consciousness the nonexistence of a certain cause; because consciousness does not tell me anything except that I do not perceive it. A similar procedure would be to measure the expanse of space by the extent of my field of vision. The conclusion, therefore, against the freewillist, is that "a consciousness of independence" would suppose an absolute chasm between me and other causes, a perfect isolation of my will at the point where it is free. But such a consciousness is impossible, because I am never certain of having exhausted reality and the various forms of existence so as to be able to say, "My will is exempt from every relation with other beings, from every determining environment, from every secret bond which could establish communication between it and the great mechanism of the world. I am alone. I am myself a universe." This pretended "consciousness of in- 
dependence" can only be an unconsciousness of dependence. ${ }^{1}$

Leaving this negative view, let us consider the positive aspect of the consciousness of freedom. Freedom is defined as absolute spontaneity, the ability to commence a movement. The will produces its action by a sort of creation ex nihilo, in the sense at least that this action is not already determined by antecedent events. Now, is a consciousness of this creative spontaneity possible? For it to be possible, I should have to be able to perceive that the foundation of my being is independent of all other beings. To be conscious of freedom I should have to be aware of what is absolute in me. To know that I am the free author of my resolution, I should need to be transparent down into the profoundest depths, and I should have to see my resolution rise from the bottom of my own nature like water rising from a spring which could regard itself as the creator of its own waters. If there remained any obscurity in any of the innermost depths of my being, I could always doubt whether the action which I thought free was not really the necessary effect of a certain nature hidden and unknown which I had not given to myself. Furthermore, this perfect knowledge of myself would have to be a priori; for I should have to see in advance the effects in their cause. Finally, I should have to be my own cause, not merely the author of my acts, but also the author of my own being.

The free-willists do not usually recognize this. They distinguish between the complete creation of ${ }^{1} C f$. Fouillée, op. cit., pp. 285, 286. 
one's self and the creation of one's acts, which they call freedom. They suppose that we have received our being necessarily, but that our volitions are freely given existence by us. If this matter is examined more carefully, however, a contradiction will appear. If there is in me a created nature which I have received, an existence of which $I$ am not the cause, there is in me a basis determined, necessitated, impenetrable to my consciousness, because not the result of my conscious action. Hence I may always doubt whether an act which appears to spring from myself does not really come from this unknown basis, - whether I may not be the slave of the nature which I have received from my Creator. I may not properly be said to be the work of another, and at the same time free in my desires and acts. He who called me into existence out of nothing, in the same process determined my nature, that is, all my properties. For no one can create without making something determined throughout and in all its qualities. So all that I do and say necessarily proceeds from the characteristics created in me; for it is only these set in motion by some external impulse. As I am, so must I act. Consequently, to be certain of being free, I should have to be wholly the author of myself, of my own being, as well as of my modes of action; and I should have to be conscious of my whole self. In other words, I should have to be the absolute existence and the absolute consciousness, or God.

If the free-willist carries his arguments to completion, here is where he ends. To be freely moral, in all the force of the term, is ultimately to be a god, since it is to be the creator of my own goodness, 
nature, and being. The free-willist cannot stop half way. He cannot maintain that my nature has been created for me. For then there is in me an existence received from elsewhere and on that account unknown and perhaps the cause of my volitions. In a word, either I have a consciousness of a free will and an absolute existence, and then am God; or else I have not a consciousness of it, and then I have not a consciousness of my freedom. ${ }^{1}$

${ }^{1} C f$. Fouillee, op. cit., pp. 286-288, and Schopenhauer, "On Human Nature," pp. 82, 83. 


\section{CHAPTER XII}

\section{FREEDOM AS ABSENCE OF EXTERNAL CONSTRAIN'T}

THE determinist would restrict the meaning of the word freedom so as to denote simply the absence of external constraint. He would not let it signify independence of the law of causation. To be free means to act out your own will. It does not imply willing without cause. To be unfree indicates action not in accordance with your own will, but under compulsion. "By freedom, whether of the will or anything else, men at large mean freedom from compulsion. What know they, or care they, about uniformity of nature, or predestination, or reign of law?"1 Spinoza defined freedom in this way: "That thing is called free, which exists solely by the necessity of its own nature, and of which the action is determined by itself alone. On the other hand, that thing is necessary, or rather constrained, which is determined by something external to itself to a fixed and definite method of existence or action." " Hume said: "By liberty, then, we can only mean a power of acting or not acting, according to the determinations of the will; that is, if we choose to remain at rest, we may; if we choose to move, we also may. Now this hypothetical liberty is univer-

${ }^{1} C f$. Hodgson, in Mind, O. S., vol. V, pp. $226 f f$.

${ }^{2}$ Spinoza, op. cit., p. 46. 
sally allowed to belong to every one who is not a prisoner and in chains." 1

In agreement with this physical signification of "freedom," both men and animals are said to be "free" if no chain, prison, maiming, or other physical restraint or interference prevents action from taking place in accordance with what is willed. Any one is free if he can do what he wills. It is exactly this liberty that the ordinary man has in mind when he claims that he is directly conscious of freedom. "I can do what I will. I can go to the right or to the left, just as I please." This is of course perfectly true; but the will to do one or the other is presupposed. The statement concerns merely the dependence of bodily action upon the will; it has no reference to the dependence of the will itself. The real problem of freedom of the will, however, is a question not of the effects of will but of the causes of will. Action depends on will; but on what does will depend? On absolutely nothing? A man can go to the right if he will it, and to the left if he will it. But has he a freedom that permits him to will indifferently either the one or the other? Under exactly the same conditions of internal disposition and external inducements, can he decide upon the one course equally well as upon the other? To say that his will does not depend upon some other person but simply upon himself, is no escape. This means simply freedom from external constraint. But will is "determined" just as truly if it is dependent upon internal causation, - upon antecedent desires, wishes, impulses, aims, education, purposes, ideals. Is man like every-

${ }^{1}$ Hume, op. cit., p. 95. 
thing else in the world, a definite being, with precise qualities, from which his reaction upon a given external action proceeds in a necessary and inevitable manner, or is he a single exception in all the universe?

"I ought" implies that "I can," and that I am not responsible for what I cannot do: this is true if by "cannot" is meant compulsion, and by "can" freedom from compulsion. It is not true if "I can" is intended to mean that " $I$ " is a first cause, not determined by anything else. If my will is forced by some power outside of me, I cannot be held accountable for what I do under the influence of that constraint. I am answerable only for that which is due to my will. Responsibility presupposes freedom from compelling pressure; but this is very different from freedom from causal dependence. Compulsion must not be confounded with causation. The force which determines the will need not be a power external to the will; it may be my own desires, ambitions, ideals, passions, habits, experiences, inheritance. Everything that happens in this world has a cause. In the case of human volitions, the motives are often obscure. Most of the time we are completely ignorant of what disposed us to desire and to will as we do. Nevertheless, the law of causation is inviolable. ${ }^{1}$

We all admit, in accordance with the ordinary sense of the word freedom, that reward and punishment, praise and blame, can be justified only on the ground that men are free, that is, that their actions are not externally constrained. But this kind of freedom, independence of compulsion, must not be confused with freedom in the special sense, that a man's voli-

${ }^{2}$. $C f$. Westermarck, op. cit., vol. I, pp. 322-324. 
tions are not caused. Of course, no one thinks of praising or blaming any one for acts performed under compulsion. If coerced, a man is no more responsible for his behavior than for that of some person over whom he has no influence. His conduct is creditable or discreditable, only if voluntary, expressive of himself, free. On this point, all agree. But we must never forget that freedom in this sense implies simply independence of outward constraint.

A free deed of mine is one that is due to my own will and not to something external that compels it. It is an act which would have been different if my will had been different. For it I am socially accountable. An unfree deed of mine is one not due to my own will but to some extrinsic force. Whether my will consents or not makes no difference in the occurrence of the action. In such a case I am not responsible. For example, if a man by force placed a gun in my hands, aimed it at another person, pulled the trigger, shot and killed the other, all by compulsion, I could not be held guilty of a crime and punished. I was not free, and cannot rightly be made to answer for the occurrence. But the free-willist does not mean by freedom the absence of external constraint. He means that volition is uncaused, a first cause, acting independently of anything and everything that has gone before.

The determinist maintains, in agreement with popular speech, that the term freedom should mean simply the ability to cause decisions and acts by one's own will. An act is free if the will of the agent is its immediate cause; it is determined, if an external force produced it, whether directly by physical con- 
straint, or indirectly, by threats and misrepresentations. To be free simply means to be able to do what one wants to do. We regard ourselves as free when no material obstruction or physiological weakness defeats our desires. Barriers on the one hand, and sickness on the other, are the obstacles which usually restrain human liberty. The gradual transition from complete freedom to irresistible coercion is well illustrated in the following supposition: "A person stays in a room because his business keeps him there, or because he has no desire to go out, or because he has been promised something to remain, or because he will be punished if he quits it, or because a sentry at the door will shoot him if he leaves, or because the door is locked and he himself is bound hand and foot. Here we have a graduated scale from perfect freedom to absolute compulsion." " Archimedes remains in his room when locked up in it or when so wholly absorbed with a problem that he has no idea of leaving it. ${ }^{2}$ Though externally constrained in the one case, and externally free in the other, he is equally "caused" or "necessitated" to remain in both cases and could not do otherwise.

Man acts freely, in the moral sense, when he acts in accordance with inner determination, a causation dependent partly upon his original disposition, partly upon the development of his character. A man who, in the presence of the impulses of the moment, is not determined by the total result of his whole spiritual past, acts not freely, but is at the mercy of whatever impulses happen to be present in

${ }^{1}$ Paulsen, op. cit., Bd., I, S. 443-444.

${ }^{2} C f$. Voltaire, "Le philosophe ignorant," chap. 13, last sentence. 
consciousness. In truth, it is not determinism that conflicts with real freedom and responsibility, but the so-called "free-choice" theory. For since no action without motive is possible, it follows that if a motive does not have to undergo assimilation and transformation by the character before influencing action, then it represents but haphazard occasion and makes of man the plaything of fortune. Shall moral action be said to be composed of chance impulsions? Hardly; rather let us say that "freedom consists in living according to reason"; or with Spinoza, that a man is "so far free, as he is led by reason; because so far he is determined to action by such causes as can be adequately understood by his unassisted nature, although by these causes he be necessarily determined to action. For liberty . . . does not take away the necessity of acting, but supposes it." 1

Determinism is sometimes said to deny selfactivity, intelligent and deliberate choice on the part of man; but this is an unfounded calumniation. It does not deny that man is intelligent and capable of deliberation and choice. In fact, it says that man must deliberate and choose; it goes even further and declares that he must make the very choice which he makes, and can make that one alone. This choice is free or his own in that it is the result, not of external constraint, but of internal causation, that is, is rendered necessary by the individual's character, by the totality of his inherited and acquired tendencies, desires, dispositions, ideas, habits, and emotions.

To say that a man's volitions are caused is not to 'Spinoza, "Political Treatise," p. 295. 
imply that he is robbed of the power of self-acting. When a person, after deliberation, reaches a decision of the will, that decision is arrived at "freely," although it is "necessarily" what it is, and could not be any different. The antecedents having been what they were, the consequent is of necessity what it is. The will, in the act called choosing, selects inevitably the course followed. It is shut up to just one choice. Even though acting "freely," the man cannot do otherwise than he does. His action is free, in that it is determined by his own will. This is free, in that it is conditioned by his own motives. These are free, in that they follow from his own desires. These are free, in that they depend on his own nature, This is free, in that it is made by his own experiences. These are free, in that they are composed of his own feelings and sensations. The sequence of causes may be traced back along the course of evolution until it reaches the rudimentary element received as a legacy from the parents.

Freedom in this deterministic sense, and as applied to intelligent beings, is simply self-control. It does not imply that the mind's effort is not controlled, but that it is directed by the individual who makes the effort, and is not coerced by some extraneous power. Thus freedom is identified with self-determination. Where it exists, there is absence of external constraint. This is the only real meaning the word can have. The determinist does not argue that man is a passive mass of flesh and bone. He says that man is self-active, and has all the abilities and activities which psychology finds him to possess. The only property denied him is that mysterious 
something called "free-will," which sits in judgment on the different motives to action and finally decides without causation what course it will take. The determinist declares that the will has not this ability. Volitions occur in a determinate order of sequence, and depend on their antecedents. Each choice is wholly determined by character and environment. 


\section{CHAPTER XIII}

\section{CHARACTER AND ENVIRONMENT}

THE determinist and the free-willist entertain opposed views concerning the nature of character. The conception of the free-willist may be represented by a quotation from Seth: "For each man there is an ideal, an 'ought-to-be'; for each man there is the same choice, with the same momentous meaning, between good and evil. To each there is set fundamentally the same task - out of nature and circumstances, the equipment given and the occasion offered - to create a character. For character is, in its essence, a creation, as the statue is; though, like the statue, it implies certain given materials. What, in detail, character shall be, in what way good and in what way evil, depends upon the given elements of nature and circumstances; whether it shall be good or evil, depends upon the man himself. Out of the plastic material to create a character, formed after the pattern of the heavenly beauty, that is the peculiar human task. . . . Must we not admit that success or failure here is determined ultimately not by the material, but by the free play of the energy of the self? Ethical, if not psychological, choice implies a real alternative." 1

When Seth asşerts that what the character shall be, whether it shall be good or evil, depends upon the ${ }^{1}$ Seth, op. cit., pp. 373 ff. 
man himself, what does he understand by "the man himself" except the character? If "the character" is made by "the man," goodness and evil are not applicable to it, but to its maker, "the man." If it is created out of plastic material by "the self," the thing of importance and the object for ethical judgment is not its nature, but the nature of "the self." What "character" commonly means is "the self," "the man." The passage quoted is a good example of confused thinking. With reference to the possibility of modifying one's character, I may avail myself of words used on another occasion. "What is meant by this possibility? Analyze the sentence, 'I have the ability to modify my character.' 'My character' is the object worked upon, and ' $I$ ' possess the ability to modify it. But what is this ' $I$ ' that chooses to modify my character? How shall this ' $I$ ' be designated? It is itself 'my character,' and you have the statement, 'my character has the ability to modify my character.' But have I two characters, one acting and one acted upon? Before ' $\mathrm{I}$ ' could change 'my character,' 'I' should have to change my ' $I$ '." ' Applying this argument to the matter from Seth, we see that before the character could be created good or evil by the man, his character would have to be already good or evil. The "choice" of goodness or evil expresses an already existing goodness or evil of character. The endeavor to push back the "alternative of choice" from "the character" to "the man himself," is but a confused play with names. It is certainly not a solution of the problem.

${ }^{1}$ McConnell, "Duty of Altruism," p. 198. 
Seth declared that "For each man there is an ideal, an 'ought-to-be'; for each man there is the same choice, with the same momentous meaning, between good and evil." In opposition to this idea, also, I quote a passage from my earlier treatise: "An ideal is not supernatural or unnatural; it is entirely natural. Its roots do not lie in something transcendental, but in the actual nature of man. An ideal is a consciousness of the will's fundamental direction or aim. ... An ideal is a necessary ideal, and fits the nature of which it is the expression. It depends upon the person for its qualities and force. It is not 'free'; it is in a chain of causation. It is the product of the particular nature. . . . Your nature you cannot change; and you cannot change your ideal. Your ideal is as good for you as mine is for me. . . . I do not exhort you to follow your ideal. I know you will follow it. Indeed, we can say, you will have to follow it, if these words are understood as containing no reference to external constraint. I can recognize no 'obligation' either to form ideals or to conform to them. An ideal means simply what is willed. . . : An ideal is as much a natural fact and subject to natural laws of sequence and causation as any other natural fact. It is an error to say that the 'self that ought to be' is morally higher or better than the 'self that is.' It is the creation of the 'self that is.' The credit for the glory of the ideal 'self that ought to be' is to be ascribed entirely to the present actual self; because it is this self that entertains the idea of that future advancement and affirms it as an ideal or good to strive for." 1

${ }^{2}$ McConnell, op. cit., pp. 207-210. 
If determinism is true, if everything that happens is determined by antecedent occurrences, why does not stagnation and fixity result in the world and in personal character? Because the lines of sequence are so numerous and so complex, and affect each other in such a variety of ways. There are no two persons exactly alike, simply because the same causes do not operate alike on any two individuals. Different forces and diverse combinations of influences produce absolute uniqueness of character. Character is individual. It is something different in every man. The fundamental traits of the human species exist in every one, to be sure, but there are such variation, diversity, and dissimilarity in the combinations and modifications of the various qualities, that we can accept the statement that the differences of moral attainment are equal to those of intellectual capacity, and that both are considerably greater than the physical differences between giant and dwarf, or between Apollo and Thersytes. The individual personality exerts a determining influence upon action. If this were not so, then all men under the same conditions would act exactly alike. But as a matter of fact, the effects of the same motive upon different men are manifold; just as sunlight turns wax white while it turns chloride of silver black, and just as heat softens wax but hardens clay. We cannot predict any effect from a perception of the motive alone; but must have in addition a knowledge of the character submitted to that influence. The special constitution of each person, on account of which his reaction upon certain incentives differs from the reaction of every one else, is what is called his character. This determines the 
way in which the various motives shall have influence upon him. There exist in every one certain tendencies to action which are occasioned by the external circumstances to accomplish themselves at this time, in this place, and in this particular way. Thus every act proceeds from two factors, - an inner and an outer, - namely, from the original nature of the person acting, and from the determining occasion which causes that disposition to express itself here and now. Upon incitement of external influences, each person reacts in accordance with his own particular nature. Character is therefore the essential factor in the production of an act. Thus we realize that our deeds proceed from ourselves, from an "I will" which accompanies all our behavior and makes us recognize it as our own and as involving us in the responsibility therefore. Circumstances are simply an occasion upon which, or an instrument through which, character expresses itself. Every person has fundamentally unique tendencies, which make up his character, and which only need external incitement in order to manifest themselves. Hence to expect that a man, upon the same inducement, should act at one time in one way, and at another time in a totally different way, would be like expecting that precisely the same tree which bore cherries this summer would bear pears next summer. ${ }^{1}$

The determinist, then, regards character as a natural product, and not as an absolute in the universe, a something independent of other existences. It is made up of the heritage received from the parents and from all remote ancestors, and of the ex-

${ }^{1} C f$. Schopenhauer, "Ueber die Freiheit des Willens," S. 46-58. 
periences met with by that original endowment. Each experience has added something to it, making it more and more complex, individual, and fixed. A man's character at any particular moment is best described as the totality of his tendencies to action. These are of course made up of inherited and acquired dispositions, - appetites, desires, passions, emotions, sentiments, ambitions, ideals. Character plays its part in the determination of every action. External stimuli furnish the occasion and inner nature gives the reaction. "Man is at any moment the sum of all his previous experience, and his response to any stimulus is colored by that experience. Thus the highly moral Christian gentleman is not betrayed into rudeness by the grossest insult. We might even go so far as to say that it would be impossible for him to be rude. Long training, together with natural tendencies, causes counter-stimuli to rise within him almost simultaneously with the insult and determine his conduct. The less-fortunately endowed and wholly uncultured individual swears volubly at a slight tread upon his toe. The action of each is the natural reaction of personality in response to stimuli - his personality being the sum of his past experience at the moment of action. Thus a person who has been reared with a profound belief in the sanctity of human life is restrained from becoming a murderer under any and all circumstances. Being what he is, murder to him is impossible. But another individual, reared in an atmosphere where revenge is a higher duty than obedience to the law, and having an inherent disposition to so regard it, kills his rival or a feud enemy as a natural expression of himself. $\mathrm{He}$ 
is no more free to choose any other course than is the keg of powder into which a live coal falls." 1

Thus character modifies our action and life more than we think. Our lot sometimes seems to have been assigned to us almost entirely from without. "But on looking back over our past, we see at once that our life consists of mere variations on one and the same theme, namely, our character, and that the same fundamental bass sounds through it all." 2

Acceptance of the doctrine of determinism need not conflict with our sense of worth. We do not regard ourselves as less estimable because the people who know us best are certain that we shall not commit some heinous crime. The will's dignity consists in the fact that its exertion is conditioned by its own individuality. I act as I do because I am I. But this " $I$ " is built up of heritage, training, and experience. The will is "free" only if this simply means action in accordance with character, the individual nature of the person. "Freedom" must not imply exemption from the law of causation, a breach in the regularity, uniformity, and invariableness of the connection of events with antecedent causes.

Determinism predicates continuity and interdependence not only in the life of the individual but also in the life of society as a whole. It asserts solidarity between peoples and generations. "History shows how each generation closely depends on the preceding and prepares the destiny of the following. One generation gets from its predecessors its physical and moral character, - not simply its size,

' Parsons, op. cit., pp. 68, 69.

2 Schopenhauer, "On Human Nature," p. 73. 
force, and exterior aspect, but also its aptitudes and tendencies (that is, its physiological heredity, of which history gets at only the results). It receives the management of its soil, cultivation, tools, dykes, roads, bridges, houses, monuments, - which in advance facilitate and mark out its material life. It derives also its economic régime, technical processes, commercial practices, credit, and debt, which condition its agriculture, industry, and commerce; - its private law, procedure, organization of the family, successions, and contracts, which determine its legal life; - its governmental organization and public institutions, which regulate its political life; - its division into classes, groups, and corporations, which decide its social life. It receives likewise all the fundamental conditions of intellectual life: its language, which imposes even the forms of ideas; - its literature, philosophy, religion, public opinion, and art, which transmit the conceptions, prejudices, antipathies, and sympathies of its predecessors; - its science, knowledge, and errors, which determine its conception of the world. In all kinds of human activity, history discloses between the generations a continuity so complete as to hide the constant renewing of society and to make it seem as if the same men existed indefinitely. Above all these solidarities, special to the individual branches of human life, there may be verified a general solidarity common to society as a whole. One generation bequeathes to its successor not only habitudes, instruments of work and enjoyment, burdens and enmities, active and passive capital; it leaves to it a general condition of well-being or languor, a beginning of progress or of 
decadence, which will react upon all forms of social activity. This general solidarity is especially produced by the two forces which exercise the most pervasive influence on societies: The one is the political organization, which regulates all the public relations between members of the nation, and which may apply for this regulation all the force of constraint, opinion, and wealth concentrated in the public authority; the other is education, which prepares all the habitudes and conceptions of the future members of society by employing all the force of compression or of example which the adult possesses over the child or the youth." 1

'Seignobos, "La solidarité dans l'histoire," Congrès international de l'education sociale, 1900, p. 46. 


\section{CHAPTER XIV}

\section{DETERMINISM NOT ESSENTIALLY MATERI- ALISTIC OR FATALISTIC}

Ir is sometimes said that determinism leads to materialism. But this is not correct. Determinism does not imply that all the causes which may be assumed to be the antecedents of human actions are forms or qualities of matter. They may be regarded as forms or functions of mind, - desires, aversions, ideas, purposes, - all regarded as distinct from material phenomena. The determinist affirms only the universal applicability of the principle of sufficient reason, - the doctrine that for every occurrence of whatever sort, there must have been antecedent causes, which furnish an adequate explanation of this event.

The determinist may be a thorough idealist, alleging that everything is mind (but declaring also that phenomena take place with regularity). Or he may be a complete materialist, asserting that everything is matter (but holding also that phenomena occur with uniformity). Or he may be a dualist and parallelist, affirming that mind and matter both exist but are independent of each other (avowing also, however, that the events in either series follow each other in determinate order and sequence). Or he may be a dualist and interactionist, maintaining that both mind and matter exist and act and react upon 
each other (and contending also that all action is in accordance with law). In short, then, determinism is not peculiar to any metaphysical doctrine of the nature of reality, but may be held by any and all.

Determinism is not essentially involved in the dispute between realism and idealism. No doubt is ever raised about the fitness of a realist professing to be a determinist. There need be just as little doubt about the propriety of an idealist espousing the doctrine. The deterministic idealist says, All that happens is in accordance with law. There is uniformity in all the events of the world. Nothing takes place without adequate cause. But "law," "causation," "necessity," are simply conceptions of mind, not independent existences. All things have the same kind of being, namely, existence in and for mind.

Nietzsche furnishes an example, when he says: "'Uncaused cause' or 'self-cause' or 'cause of itself' is the best self-contradiction that has ever been thought of. It is a kind of logical rape or unnatural deed. But the excessive pride of man has got him horribly entangled in that nonsense. The demand for 'freedom of the will,' in that metaphysical superlative sense, in which it unfortunately prevails in the heads of the half-instructed, the demand to bear the whole responsibility for one's actions, and to free God, the world, ancestors, chance, and society from responsibility, is indeed nothing less than a demand to be that 'cause of itself,' and, with more than Münchhausen's audacity, to lift one's self by the hair from the bog of nothingness into existence. Assumed that any one gets beyond the boorish simplicity of this celebrated conception of 'free-will,' and 
brushes it out of his head, I beg him now in addition to carry his 'enlightenment' one step farther and clear his mind of the reverse of that unmeaning conception 'frec-will.' I mean the 'unfree will,' which amounts in the end to an abuse of cause and effect. 'Cause' and 'effect' ought not to be mistakenly objectified or materialized, as the naturalists do (and those who like them naturalize in thought), in accord with the prevailing mechanical doltishness, which lets the cause press and push until it produces the effect. Cause and effect should be used as pure conceptions, that is, as conventional fictions for purposes of designation and understanding, but not of explanation. 'In itself' there is no 'causal connection,' no 'effect following upon its cause,' no 'reign of law.' It is we alone who have devised cause, sequence, relativity, compulsion, number, law, freedom, ground, purpose; and if we in fancy place this symbolic-world as 'in itself' in existence, we proceed again, as we have always proceeded, mythologically." 1

Scott also gives some statements which show how idealism and determinism are compatible. "Laws of nature are the character of mind; and the reason why they must prevail in nature is, that a nature which mind can know must bear the character of mind on its face. Laws, then, are at root mind's essence. At first glance, of course, they seem to have nothing to do with mind. They are characteristics of the natural order. They are the great binding uniformities whereby the world is the world and without which it would all fall loose. But essentially they are also the binding conceptions whereby the

${ }^{1}$ Nietzsche, "Jenseits von Gut und Böse," S. 32 ff. 
mind is the mind and without which it would fall asunder. They must, therefore, characterize everything which the mind can know. Their universal validity is proved by their source. Their derivation from mind makes them universal for all objects of mind. . . . The causal system, if the doctrine of Kant have any truth, must be all-embracing. It is one expression of that law-abiding character of the universe which makes the latter an object of knowledge. Hence the causal system stretches as far as the knowability of the universe does; and that means all the way. For where the universe ceases to be knowable, there (at least, if we follow the postKantian interpretation of Kant) it ceases to be. And with this result the possibility of freedom seems to vanish. Man is a denizen of this universe. Everything which is in the universe at all, every act and event and object, must conform to the conditions of knowability; and to be causally construable is one of these." 1

Determinism is not essentially fatalistic. Fatal, ism teaches external compulsion; it believes the individual to be constrained by outward power; it is a denial of all responsibility. But determinism is very different; it considers a person the product of causes, many of which are internal; it regards his will, not as forced by extrinsic causes, but as made by causes which are in the main intrinsic. When we say that a man is subdued by fate, we regard him as existing independently of that which subdues him, we attribute to him an innate character which is acted upon from the outside. He would be different if fate had

${ }^{1}$ Scott, op. cit., pp. 336, 337. 
left him alone. But it means absolutely nothing if we say that he would be different if the causes to which he owes his existence had been different; for instance, if he had been the offspring of other parents. This shows that we distinguish between the original part of a person and the part which is the product of . outer circumstances. His character belongs to his original self; and, it is on the character only that the moral judge passes his judgment, carefully considering the degree of pressure to which it has been exposed both from the non-voluntary part of the individual and from the outside world. According to the fatalist, character is compelled; hence personal responsibility is out of the question. According to the determinist, character is caused; but this has nothing whatever to do with the question of responsibility. ${ }^{1}$

Mill gives the following clear description of fatalism, showing its difference from determinism. "When the belief in predestination has a paralyzing effect on conduct, as is sometimes the case with Mahomedans, it is because they fancy they can infer what God has predestined, without waiting for the result. They think that either by particular signs of some sort, or from the general aspect of things, they can perceive the issue toward which God is working, and having discovered this, naturally deem useless any attempt to defeat it. Because something will certainly happen if nothing is done to prevent it, they think it will certainly happen whatever may be done to prevent it; in a word, they believe in Necessity in the only proper meaning of the term${ }^{1}$ Cf. Westermarck, op. cit., vol. I, pp. 320-326. 
an issue unalterable by human efforts or desires. . . . Pure . . . fatalism holds that our actions do not depend upon our desires. Whatever our wishes may be, a superior power, or an abstract destiny, will overrule them, and compel us to act, not as we desire, but in the manner predestined. Our love of good and hatred of evil are of no efficacy, and though in themselves they may be virtuous, as far as conduct is concerned it is unavailing to cultivate them." 1

It is often said that acceptance of the doctrine of determinism kills the sentiments of hopefulness and effort, and leads inevitably to inaction and discouragement. Is this true? Each individual is the result of a multitude of conditions, partly known, mostly unknown. In accordance with these determining causes, he is energetic or indolent, brave or cowardly, strong or weak. Belief in the universality of causation is, like any other event in the world, both an effect and a cause. The person who is led to accept determinism recognizes that all his volitions and actions are caused; he realizes also that in their turn they are causes. Consequently, the doctrine need not lead to inactivity and despondency. It may discourage one person from further exertion, but could do this only in case the other influences to which he owes his character concur in producing this result. It may lead another individual to more intense action, greater effort, and stronger hopefulness; because the other determining conditions of his disposition coöperate in accomplishing this result. Logically, the doctrine of determinism provokes continual struggle; for the individual knows that his endeav${ }^{1}$ Mill, op. cit., pp. 298, 303, 304. 
ors will necessarily and inevitably produce effects. So the energetic individual feels internally constrained to put forth effort; it is his nature to do so; and he lives out his nature. Born of vigorous parents, and living in a circle where the strenuous life is the one that receives praise and reward, he cannot help being active. Thus, although a firm believer in the reign of law, he is both hopeful and energetic.'

Determinism maintains that the causes of our actions are in the main internal. Will is not "a first cause"; its dependence extends back into the infinite past. It is conditioned by our desires, which, in turn, depend on still antecedent causes. Every motive is such only through our own character. External influences do not become motives except by being assimilated by our own nature. An act that takes place as a result of our character under certain circumstances is not properly called a "fatal" act. It is "necessary," "determined," "caused," but not "fatal" in the ordinary sense of the word. It is not produced by external causes, forces acting apart from, and even contrary to, our own will. It is the product of both character and environment; it is the joint effect of both internal and external influences. To ignore either of these factors is wrong. By "character" is meant simply the sum of tendencies to action, the total disposition, which has resulted from all past experiences or causes, and acts as a totality in the presence of contemporary influences. In the present moment my character responds to stimuli as a concrete totality. In the following moment it will have been modified by this additional experience. 
Some new element or elements will have been incorporated. It is not an "uncaused cause." It has undergone a long and complicated growth and development, extending back to the first rudimentary legacy from the parents.

Thus, while determinism asserts continuity, uniformity, regularity, invariability, constancy, law, causation, necessity, or whatever term best expresses the conception, it differs from fatalism in that it maintains that a man's acts are the result of internal as well as external causes. The action of a man, in spite of the necessity with which it proceeds from his character and motives, is nevertheless his own; or, better, is his own, because it proceeds with necessity from his character and motives.

It is its kinship with fatalism that causes determinism to be feared and rejected by so many people. They turn away from it as though it implied a revolting slavery to evil impulses and appetites, and a suppression of morality. They do not realize that man may be determined to goodness, to beauty, to moral laws, and may obey noble impulses of sensibility and exalted motives of intelligence. They do not realize, either, that the sinner in the way of evil may find the narrow way again. "The culprit in the bondage of a low sensualism may pass under the yoke of good and may submit henceforth to the lead of intelligence and moral ideas. Each action is an effect. It could neither not be nor be otherwise. It is the inevitable product of the agent's character and circumstances at that exact moment. The criminal could have avoided his crime if his personality had been other than it was, if his mentality had not been clouded 
by fatigue, by sickness, or by alcoholic intoxication, if he had kept his moral instruction in mind, if restraining ideas had been twice as strong. But all these ifs are useless; they come too late. Given the efficacious attractions and repulsions, and the deed has been accomplished, with all its unhappy consequences to the individual, his family, and society. But it is nowhere written that the wrongdoer is going to persist henceforward in a downward course, and that he is forever delivered to evil. A fault having been committed, now is the time for society to bring educative influences to bear on the individual, so as to arouse in his soul favorable tendencies to action, intellectual incentives to goodness, reasoned sentiments of moral duty. ${ }^{1}$

${ }^{2}$ Cf. DuBois, op. cit., pp. 51-55. 


\section{CHAPTER XV}

\section{REIVARD AND PUNISHMENT}

THE determinist, maintaining that acts are caused by character under the stimulation of circumstances, holds that determinism alone affords a reasonable justification for praising or blaming, rewarding or punishing, a person for his behavior. He says that since the free-willist claims that a man's acts are not determined by inner nature under the incitement of external conditions, but are produced by "free-will," he has no vindication for reward or punishment, praise or blame. The only reason for punishing for crime is on account of its relation to the personality of the culprit. The deeds themselves are, by their very nature, merely temporary and perishing; and if, as the free-willist holds, they result not from some cause in the disposition of the person who performed them, they can entail no infamy upon him. They may be harmful; they may be contrary to all rules of morality and religion; but the person cannot be made answerable for them and punished; since, in the indeterminist's doctrine, they proceeded not from any enduring cause in the individual's nature. In the free-willist's opinion, therefore, a man may be as pure and untainted, after having committed the most horrible crime, as at the first moment of his birth; nor is the man's character anywise concerned in his actions, since they are not derived from it; and 
the wickedness of his conduct can never be used as a proof of the depravity of his nature. Why is it that we do not blame any one for injurious actions if performed unintentionally? Simply because we know that the resulting injury did not spring from his inner self. Actions are objects of our moral resentment or approbation only in so far as they are indications of badness or goodness in the internal character. It is impossible that they call forth praise or blame where they proceed not from character but altogether from chance or external violence. ${ }^{1}$

Does the assumption of freedom contribute anything toward the solution of the problem of punishment? If my crime was a free one, there is no warrant for punishing either for having done it or in order to prevent its recurrence. It was not determined by either character or environment. I did not do it. Who can cause what is causeless? By no possibility could I have averted it. Who can take' precautions against the spontaneity of freedom? Why punish me for what $I$ did not do and could not possibly have prevented? Is the punishment intended to ward off a repetition of the deed? Certainly not. It cannot make such changes in my mind or body as to determine the non-occurrence of acts which are by hypothesis independent of what is contained in my character and environment. Ordinarily, before judging behavior we try to find out something about its setting. An act is good or bad according to its motives and intentions. But under this theory of "freedom," we cannot ask for the causes of the action. For just in so far as it was

${ }^{2} C f$. Hume, op. cit., pp. 102, 103. 
"free," it cannot be accounted for by any ideas antecedently in my mind, or by my natural instincts. Hence it is an act without a setting - causeless, purposeless, blind. Is it creditable? Are such acts the only creditable ones? The freedom which means that my conduct need not result from anything that has preceded it, even my own character and impulses, inherent or acquired, is seen in its implications to be something very serious and terrible. Suppose that I am endowed with this freedom, can I call it mine? Suppose that I have given money to a beggar. If the deed was really an act of "free-will," can I regard myself as its author? What though I be a man of tender heart, of benevolent impulses, a lover of my race, and naturally incited by the sight of suffering to make an effort to relieve it - these things could have had nothing to do with causing the benevolent action. It was the result simply of "free-will," and might equally well have been accomplished through some one else, through even the most unfeeling brute upon the streets, a man whose impulses are all selfish, and whose past life is a consistent history of sordid greed. If it was "free," it was not conditioned by antecedent circumstances of any kind, by the misery of the beggar or by my pity for him. It was causeless, not determined. Furthermore, if my acts have no necessary congruity with my character, what guarantee have I that my life will not exhibit the melancholy spectacle of the reign of lawlessness, impurity, and crime? It is wholly impossible for me to guess how I shall "freely" behave. And I cannot make any provision against consequences of the most deplorable sort. Can my "free" will be 
trained by a course of education, or laid in chains by life-long habit? In so far as it is "free," what I have been, what I am, what I have always done or striven to do, what I most earnestly wish for or resolve upon at the present moment - these things can have no influence toward deciding my conduct. If I am "free," I must face the possibility that I may at any moment be guilty of any crime that any man can commit. The possibility is a hideous one. If willing is "free," there is little use in laboriously schooling my desires to virtue, since at any instant, in spite of this training, some unmotived volition may bring forth from me a detestable deed. The dilemma cannot be avoided. Volitions are either caused or they are not caused. If they are not caused, an inexorable logic brings us to the absurdities mentioned. If they are caused, the free-will contention is annihilated, and determinism holds the field. ${ }^{1}$

The practice of punishment can derive no justification from the free-will doctrine. If the malefactor willed "freely," if he acted badly not because he was of an evil disposition but for no reason whatever, we cannot prove the justice of punishing him. That he was beyond the influence of motives might make it right to keep out of his way, or to place him under bodily restraint, but not to inflict pain upon him, when, by supposition, this could not operate as a deterring motive.

If the will is "free," what is the use of punishment? It cannot be reached by external means, by the ap-

${ }^{1}$ Cf. Fullerton, "Freedom and Free-Will," in Popular Science Monthly, vol. LVIII, pp. 183-192; and "Free-Will and the Credit for Good Actions," in Popular Science Monthly, vol. LIX, pp. 526-533. 
plication of pain to the body. The sensibility has not caused the wrong-doing; it has been simply an instrument in the hands of the free will. What sense is there in making it suffer? Why inflict a sensual pain upon the morally bad person, if the moral sphere is raised high above influence from the physical sphere? How can absolution for wickedness be obtained through physical suffering? The moral evil in the free-will remains there regardless of how much pain is inflicted upon the innocent body. The freewillist says, If the mysterious cause of your actions, your free-will, is good in itself, we will give a pleasant and agreeable sensation to your sensibility; but if that free-will is bad, we will make your sensibility suffer. This is an irrational procedure; and has absolutely no reference to future effects. It is practically and socially unjustifiable and useless. Between free-will and afflictive penalty there can be no connection. Free-will could be punished only in case it willed to chastise itself, and could do this only if already good, and hence in no need of chastisement. Thus the bad will has to be converted before it can be punished; and its conversion makes punishment unjust.

The free-willist says to the determinist, You have no right to inflict penal suffering, if the criminal's act is the necessary result of natural laws, and could not have been averted. The determinist replies, Yes, exactly. Therefore we do not regard punishment as a retribution or expiation for past offences, but as a motive and guarantee of future good behavior. It is given in order to obtain certain effects. It is not to requite the criminal for his evil deeds, for 
they are past and gone forever, but is to deter him from repeating his crimes, or, in other words, to protect society. It is regarded simply as an added cause to bring about future good conduct. We deny a responsibility that depends upon freedom of choice, but we affirm a responsibility that depends upon character. The criminal's nature is the cause of his act. And just as we hold that his disposition has been determined by past influences, we also believe that it may further be determined by present and future influences. So we administer this punishment in order that it may affect his character and make it better.

The free-willist further protests, Why punish this man? That is unjust. You ought to punish his ancestors and his fellows, but not him. They are the forces which have made him what he is, and they alone are responsible. The determinist replies, We punish the criminal himself. When a person is sick, it is to him that we give medicine that it may have good effects upon his body and bodily action. When any one is criminal, it is to him that we administer punishment, that it may have a good influence upon his mind and lead him to better actions in the future. If a diseased person imperils others, he is isolated. Likewise, the dangerous criminal is confined. The object in both cases is the same,- not to punish the subject, but to protect society, and also if possible to cure the afflicted person and to make him a useful member of the social body. The fact that we do not consider the criminal morally blameworthy does not cause us to deal with him in a manner dictated by sentimental pity. We give him a treatment that is 
regarded as efficacious to accomplish the end desired, - first, the protection of society, and secondly, the cure of the malefactor and his restoration as useful and constructive instead of useless and destructive, a danger and an expense. Moreover, realizing that crime results from definite causes, we try to discover these in the environment, and to get rid of them. Determinism encourages preventive measures whose object is to anticipate the causes of crime and to counteract them.

The free-willist asks, Why do you not punish also idiots and imbeciles? The determinist answers, Because it is impossible to work upon their intelligence and to determine their future actions for good. This is the object of punitive dealing, to insure good results. But the man without understanding, the imbecile, cannot learn; and so it is as useless to punish him as it would be to punish a piece of wood. The idiot may not be influenced and corrected. He cannot be deterred from acts by being chastised for them. His behavior does not follow from reflection, deliberation, and reason, but is purely reflexive, impulsive, irrational. The normal man, however, is capable of instruction and of acting under the dictates of reason. Punishment in his case exerts the desired influence. Laws and penalties are causes and means of determination for intelligent beings.

The free-willist inquires, If the sole object of penal discipline is to obtain good future results, would it not be well to give every one an occasional flogging? The determinist replies, This misses the point. There would be no object in chastising where no harm had been done. It could not be expected to serve 
as a counteracting agency at some definite point of danger.

The determinist renounces trying to suit the punishment to the moral depravity. He administers it as a measure of social security. He justifies it on grounds of social utility, without reference to the ultimate moral nature of the individual, or to the culprit's metaphysical freedom and responsibility in acting as he did. He considers the criminal bad as the necessary result of the operation of natural laws, - heredity and training. He inflicts corrective discipline, not to atone for moral iniquity, but for its social usefulness and for its beneficial effect on the character of the sufferer. The principal aim is to influence future behavior. The past deed was a necessity and could not have been helped. But future action is yet a possibility, and punishment is inflicted in order to add the weight of other inducements to prevent repetition of the damage. The criminal code is a catalogue of opposing motives to criminal actions. Laws and penalties are means of determination for beings who think. The idea of future punishment exercises a restraining force on conduct. Legal ordinances endeavor to make the incentives to right action outweigh those to wrong action. And just so much greater the damage that may result from a crime, so much the greater must the motive be made which is to prevent the occurrence of the deed. All this is on the supposition that the will is not free but may be determined, caused, necessitated.

The determinist believes in the operation of natural law in the mental realm; and applies punish- 
ment to a man in order to influence his understanding and conduct. The criminal's act may be the result of ignorance on his part. Corrective discipline educates him. Or his deed may be the consequence of imperfect organization between the intellect and the emotions. Penal suffering assists in securing the domination of intelligence, by showing the man that passion and desire heedlessly gratified lead to excessive pain. Thus punishment is educative, and assists reason in securing the mastery.

The problems of education depend on investigations concerning the nature of the human mind and the possibility of improvement. When a philosophical doctrine shows itself incompatible with the fundamental conception of pedagogy, namely, the plasticity and cultivableness of the pupil, as the theory of indeterminism does, its claims for acceptance must be carefully scrutinized. Indeterminism declares the will to be free in the sense that it may choose a direction just the contrary of the determining influences and causes. The incompatibility of such a view with pedagogical objects is evident. Where the possibility of a causal relation between educator and pupil is excluded, where the mental and spiritual condition of the pupil appears causelessly changeful every moment, there any education must be considered impossible, and any attempts at it must be regarded as foolish. ${ }^{1}$

Administering punishment for the purpose of preventing repetition of a harmful deed is based on the natural laws of psychology. It becomes an additional motive for good behavior. The idea of pain becomes

$$
{ }^{2} C f \text {. Rein, "Pädagogik," S. 75, } 76 .
$$


associated with the idea of a certain action, and this association of ideas will deter from that action. The advocate of man's freedom of will would not admit that animals are free moral agents; yet they punish them. They whip their dogs and horses, to teach them better behavior. Why not admit the same efficacy in the punishment of man? Penal suffering may waken his slumbering reason; it may instil a wholesome fear of doing certain things. In the eyes of the determinist, there is more to be hoped for from punishment if man's acts are determined than if they are the results of absolutely free will.

Using the inclusive formula of "punishment for social protection," the determinist may inflict chastisement for this object. He believes that society is adequately protected only in case the person criminally inclined is (1) made to realize that harm done by him will be requited; (2) deterred from acting out his disposition; and (3) reformed, and thus the possibly destructive force changed into a permanently constructive one.

If a man feels inclined to commit a bad action, society may induce him to refrain (1) by exciting sufficiently great fear of punishment or vengeance; or (2) by instilling superstition, in other words, dread of punishment in a future life; or (3) by arousing feelings of sympathy and general charity for others; or (4) by appealing to his sense of honor, in other words, the fear of shame; or (5) by quickening his sentiment of justice, that is, the objective attachment to fidelity and good faith, coupled with a resolve to hold them sacred, because they are the foundation of all free intercourse between man and 
man, and therefore often of advantage to himself as well. ${ }^{1}$

Most important of all, however, the determinist places his faith in the aim at prevention of crime. Recognizing that there are certain determinate causes of wrongful acts, he tries to find them out and to apply such treatment as to counteract and overcome them. He hopes that through natural evolution and through man's discovery and scientific use of social forces, crime may be eliminated from society and criminal tendencies eradicated from the nature of man.

${ }^{1} C f$. Schopenhauer, "On Human Nature," pp. 97, 98. 


\section{CHAPTER XVI}

\section{THE NATURE OF LAWS}

Aristotle maintained that virtue and vice are voluntary, and that the existence of laws attests it, since no one makes laws for animals or for automatons submitted to necessity. That virtue and vice are voluntary "seems to be attested, moreover, by each one of us in private life, and also by the legislators; for they correct and punish those that do evil (except when it is done under compulsion, or through ignorance for which the agent is not responsible), and honor those that do noble deeds, evidently intending to encourage the one sort and discourage the other. But no one encourages us to do that which does not depend on ourselves, and which is not voluntary: it would be useless to be persuaded not to feel heat or pain or hunger and so on, as we should feel them all the same." 1

Many others, since Aristotle, have repeated the objection that the threat of punishment and the promise of reward could not be effective with reference to a being subject to necessity, any more than with refference to a machine. This objection rests on a confusion between the material and the intellectual. Man, according to the determinists, is a machine that thinks and has for springs ideas. Each thought is a tendency to action. The conception of future pun-

'Aristotle, "Nicomachean Ethics," Book III, sec. 5. 
ishment is a force that is able to counteract certain other forces in the mind of man. Hence, legal penalty may be efficacious, even though man be necessitated in his behavior. When punishment is applied to a being impelled by interests, like an animal, pain takes place; and the idea and fear of future suffering may be a force leading to the avoidance of the acts with which the suffering is connected. In fact, laws and punishments might be without any efficacy whatever on beings whose wills were "free." But they are causes and means of determination for persons who are determined by ideas and feelings. Their power is greater and more certain without freedom of the will than with such an incalculable resistance."

Hamilton argued that the existence of moral laws attests the reality of freedom. "Practically, our consciousness of the moral law, which, without a moral liberty in man, would be a mendacious imperative, gives a decisive preponderance to the doctrine of freedom over the doctrine of fate. We are free in act, if we are accountable for our actions. ... We have, and can have, no ground on which to believe in the reality of a moral world, except in so far as we ourselves are moral agents. ... But in what does the character of man as a moral agent consist? Man is a moral agent only as he is accountable for his actions - in other words, as he is the object of praise or blame; and this he is, only inasmuch as he has prescribed to him a rule of duty, and as he is able to act, or not to act, in conformity with its precepts. The possibility of morality thus depends on

${ }^{1}$ Cf. Guyau, "La morale anglaise contemporaine," pp. 361, 362, and Fouillée, "La liberté et le déterminisme," p. 36. 
the possibility of liberty; for if man be not a free agent, he is not the author of his actions, and has, therefore, no responsibility - no moral personality at all." 1

Janet, also, argued that freedom was proved by the existence of the moral law. "Suppose that man be not free: either he would be constrained to accomplish the law by an irresistible necessity, and then the law would be vain; or he would be prevented by necessity from fulfilling it, and then it would be senseless. To say 'Do this' to some one who cannot help doing it, is useless; to say it to some one who cannot possibly do it, is absurd. Moral action is represented in the form of an ideal in the mind of the agent, and is imposed as a command. This command would be futile and foolish, if man, by his very organization, were but an automaton constrained to do, or prevented from doing, what the law commands." 2

This sophistry is due to a laziness of thinking which refrains from instituting causes for the effect desired. It is like abstaining from battle on the pretext that if victory is necessary, combat is useless; while if victory is impossible, contest is absurd. Similarly, in the preceding argument, Janet forgets that the promulgated law, with its motives influencing intelligence and sensibility, may become one of the factors of its own realization. A command, like a threat, is therefore neither useless nor absurd in the hypothesis of determinism, because it is itself a force to move

'Hamilton, Appendix to "Discussions," pp. 624, 625, and "Lectures," i, 32, 33 .

"Janet, "Traité de psychologie," p. 303, quoted by Fouillee, "Critique des systèmes de morale contemporains," pp. 282, 283. 
the automaton of intelligence and feeling. If an objector declares, "Laws would not have, in such a case, any moral character, since they would be realized only in the way of determinism," the reply may be made: This reduces simply to the statement that if man be not free, morality can no longer mean the morality of free beings. No one denies this. If any one begins by defining morality in a manner to imply free-will, he presupposes the very thing that is in question. The free-willists simply show that determinism cannot found a morality like their own, that is, a morality implying the freedom of indifference, the ability to choose contraries, the privilege to act without determination by motives. But the question is, whether such a morality is true, whether it is the legitimate interpretation of the facts. Perhaps science can dispense with the conceptions of freewill, absolute imperative, and moral sanction. The free-willists think these should be taken for granted. But this is not so. The facts indicate that human life and society are perfectly possible on the basis of determination of ideas and of ideal action. ${ }^{1}$

Kant said: "Morality is possible only for a free being. Now I say that a being who cannot act except under the idea of freedom, must on that very account be considered free so far as his actions are concerned. In other words, even if it cannot be proved by speculative reason that his will is free, all the laws that are inseparably bound up with freedom must be viewed by him as laws of his will. And I hold, further, that we must necessarily attribute to every rational being that has a will the idea of freedom, because every

${ }^{2} C f$. Fouillee, op. cit., pp. 282-284. 
such being always acts under that idea. We must believe that a rational being has a reason that is practical, that has causality with regard to its objects. Now, it is impossible to conceive of a reason which should be consciously biased in its judgments by some outside influence, for the subject would in that case look upon its decisions as determined, not by reason, but by a natural impulse. Reason must therefore regard itself as the author of its principles of action, and as independent of all external influences. Hence, as practical reason, or as the will of a rational being, it must deem itself free." 1

To ethical writers who champion a formal, $a$ priori, unconditional, categorical moral obligation, freedom is essential; and since they are unable to prove it, they finally accept it without proof and as a necessary postulate. The moral law, according to Kant, is certain by itself. We are immediately conscious of it. The certitude of its existence conducts us to the absolute assurance of the reality of freedom. Freedom is essential to the moral law, and must be postulated. "Freedom is a pure idea, the objective reality of which can in no wise be proved according to the laws of nature; nor can it be given to us in any possible experience; and, escaping every analogy and example, it may not be comprehended or even grasped." 2 Now to be satisfying it is necessary for ethical theorists to deal more scientifically with this problem. If they believe in freedom, they should show reasons for the faith that is in them. To their doctrine freedom forms an indispensable adjunct.

${ }^{1}$ Kant, "Grundlegung zur Metaphysik der Sitten," sec. III. ${ }^{2}$ Ibid. 
Their moral law commands categorically and unconditionally, "Do this." But may I not inquire whether it is possible to execute the order? If the impossible is demanded, I cannot accomplish it. An imperative is dependent upon the power to obey it. Nothing can be a duty that cannot be performed. The ability to act must be decided before action can be said to be obligatory. If one went into a school for the deaf and commanded them viva voce to run, would obedience be due? If one went into a ward of paralytics and bade them run, would they be bound to execute the order? Obligation would be nullified by the inability to hear and understand the command in the first instance, and by the incapacity to execute it in the second. The power to carry out an imperative should be investigated before the imperative is declared obligatory. "You can because you ought" starts at the wrong end. The "can" must be decided before the "ought."

A method is too short and easy that dispenses with an investigation of moral capacity and simply says freedom is a necessary condition of the moral law, therefore man is free. We may begin at the other end and distrust the certainty of freedom, and thus raise doubts about the moral law. A freedom that is hypothetical can ground only a hypothetical obligation. If man cannot know that he is really free, he cannot know that he is really obligated. He is bound to do only what he can do. The moral law cannot be considered absolute without belief in the absolute power to do what it commands. The moment the ability to act comes under suspicion, the obligation to act is rendered uncertain. 
It is contradictory to affirm that obligation is certain while freedom is uncertain. If freedom is uncertain, obligation is doubtful, and performance of it problematical. When any one says that freedom of the will contradicts all the known laws of science and is incomprehensible to our understanding, why should he still declare that it must nevertheless be postulated for the sake of the moral imperative of which it is the necessary condition? Why not rather doubt the moral imperative? If freedom be a prerequisite of morality (of the unconditional sort), let us not meekly assume its reality; let us investigate whether freedom is a wrong conception and the morality based on freedom must be given up.

It has been held in the past, and is too often thought at present, that moral needs have the primacy in the determination of truth and the guidance of conduct; or in technical terms that "practical reason" takes precedence over "theoretical reason." For example, it is believed in regard to immortality, that the proper method of investigation is not a scientific search for facts to establish or to disprove it, but a consideration of its need for the purposes of morality. Immortality must be postulated for the sake of moral obligation. The arguments are "moral arguments." The injustice of this world demands a future world in which justice shall reign; the apparent triumphs of evil in this life call for an afterlife in which good shall obtain the final and enduring victory; the incompleteness of our present existence renders further existence necessary for completeness; the soul's capacities do not receive full exercise now, so must have larger opportunity hereafter; the social 
feelings of love and friendship require a reunion with dear ones in a future state; - these and similar moral needs are declared to have the primacy in the determination of whether there is a life after death. The scientist who would submit the phenomena to scientific investigation is proclaimed not only mistaken in his method but a reprobate in character and deserving of social punishment. Certain foundations of morality must not be tampered with. How inspire the masses with restraining fear if the consuming wrath of God is not preached? How maintain the practice of goodness if the fear of hell is removed, or any tenet of religion undermined? There are realms in which intellect and reason are out of place. In these spheres reason must not attempt to acquire positive knowledge, or formulate statements of probability. Action in moral matters is to be guided not by experience of facts and reasonable conclusions therefrom, not by demonstrable truth or the most probable conclusions in the absence of exact certitude, not by ideas of objective facts and relations capable of analysis and criticism. Reason must be neither scientific nor philosophical, but must be converted into blind faith, the adoration of mystery. The primacy is given to moral needs and religious belief. Morality is not subject to science and philosophy; they are subject to it. The principles of morality are above investigation and criticism; they transcend reason. The ground of obligation is in a religious creed. In the absence of perfect knowledge, conduct is not to be regarded as problematical, uncertain, risky; it is always and unquestionably sure, being directed by "spiritual insight." 
What shall we say of such views? Shall we admit that science is gracefully to retire when in the presence of certain sacred things? Is truth to be determined by "practical needs" and not by "cold reason"? Are the known and knowable to be subordinated to the unknown and unknowable? Are certitude and probability to be exchanged for transcendency and mystery? No. Reason is to be applied to anything and everything. These "practical needs," "spiritual insight," "religious faith," are not supreme, but must submit to examination and trial. Reason is to guide our actions, not most of the time, but all the time. It must never surrender its leadership or yield to a mystery. Man is not called upon to prostrate himself before a categorical imperative of the pure practical reason, or before a command that falls from the clouds. Truth must not be judged by its accord with man's "moral or practical needs," real or imaginary. A system of ethics grounded upon the transcendent, the mysterious, the metempirical, has no solid foundation.'

All laws, then, whether "natural" or "moral," are conditional. Many people hesitate to place the social sciences on a level with the physical sciences, because they think the latter belong to the realm of inexorable Necessity, while the former belong to the realm of Liberty. They believe that the physical sciences deal with matters which cannot help taking place, while the social sciences are concerned with things which may or may not occur, according as free

${ }^{1}$ For further consideration of this subject, see the author's "Duty of Altruism," chapters on "Theology and Obligation" and "Metaphysics and Obligation." 
human wills decide or choose. The physical sciences admit of an exact prevision of what fact will succeed or accompany another fact. Thus the astronomer can calculate the exact minute at which an eclipse will take place a thousand years from now; and the chemist knows precisely what will be the result of combining chemical substances under certain conditions. On the other hand, unfailing prediction is impossible in any of the social sciences. The social worker, the economist, and the statesman can only form more or less trustworthy surmises concerning the movement of social, economic, and political events. Is this difference in possibility of forecast due to the fact that the physical sciences are governed by "natural law," while the social sciences depend on the "free-will" of the actors; and "free-will" is capricious, while "natural law" is an inflexible power" which commands unconditional obedience? No. A "natural law" is really nothing but a uniform way of behavior which spontaneously arises in the relations of things or men. This mode of acting may, indeed, be called "necessary"; but it is "necessary" only in case certain foregoing conditions are fulfilled. For example, atoms of hydrogen and oxygen do not necessarily form water; but if, under certain conditions of temperature, pressure, etc., an atom of oxygen is placed in contact with two of hydrogen, they will unite to produce water. Now precisely similar is the action of men, these "free moral agents." Men are not obliged to buy and sell, unless certain foregoing conditions have been fulfilled. But if a man disposed to sell meets a man disposed to buy, and if their offers are mutually acceptable, they will "neces- 
sarily" make a transaction at a determinate price. This transaction of these "free moral agents" is exactly as "free" or "necessary" as is the action of chemical substances or the movements of astronomical bodies. ${ }^{1}$

What is the relation between the "ought" judgment and the "is" judgment? Many writers on ethics maintain that the "ought" is essentially different from the "is," and can never be resolved into it. The dissimilarity, it is said, between a description of fact and a norm of reason is fundamental. Reason often declares the opposite of the present to be morally due. The actual is not in harmony with the ideal; history does not conform to morality; nature is not in agreement with reason; the "is" does not correspond with the "ought." In a person's own life the perception of the discrepancy between what is and what ought to be is the call to duty. One is obligated to try to make the real accord with the ideal. Thus, the "ought" implies something more than facts. It implies superiority over them. It sits in judgment over the real, and constitutes a mandate for the will to make and modify it. The opinion championed in this treatise holds that the "is" is the more basal, and that the "ought" depends upon it and derives all its force from it. . Reason is dependent upon the actual facts for its norm. What ought to be is obtained from a consideration of what is; it is a conclusion from the observation and comparison of the facts of experience, and the discovery and generalization of their laws. "The ideal" which is said to be better than "the actual" is nevertheless

${ }^{1} C f$. Gide, op. cit., pp. 5 ff. 
based upon it, and is merely the actual represented in different combinations. The idea in which something appears as better than the present is a psychical phenomenon, and subject to psychical laws. The law of causation reigns in the mental realm just as truly as in the physical.

The objection is raised, "But the ideal contains two distinct characteristics: one presenting the actual present, the other representing a possible future. It is the latter element that saves the ideal from determinism, that is, from the "is." "To this objection, we reply, The representation of a "future possibility," is dependent upon present and past actualities for its existence and power. It has validity for some one, some disposition, some character, which, if other than it actually is, would not have formed such an ideal and would not respond to it. An ideal is yours or mine, and depends upon you or me, upon present and past causes, from which it derives all its qualities and force. It is not "free"; it is a product; it is in a chain of causation. You have such and such an ideal, because your nature is what it is. I have a different one, because my character is unlike yours. An ideal is to be accounted for by the disposition of which it is the expression. How diverse the ideals of a Negro, a Chinaman, an Italian, a Norwegian, an Englishman, an American! And how various the ideals of the individuals within a race, on account of the dissimilarities in parentage, status, education, business, and religion! Thus actual events and actual character account for an ideal and its strength.

At one time even physical occurrences were looked upon as irregular and capricious. But the science of 
physics now regards law as reigning universally; for instance, the law of gravitation expresses the constant behavior of all masses in the universe toward one another, and may be determined with mathematical accuracy. Biology in its various branches was longer supposed not under law. But more and more the exceptions, the variations, the sports, the freaks, are being accounted for, explained, and seen to observe uniformity. It is only the greater complication of the occurrences in biology than in physics that makes the difficulty. The reign of law is the same in both. In all branches of human interest there has been going on this progress toward definite science, the accurate discovery and determination of regularity. Human conduct is slowest of all in moving this way. It is still regarded most generally as a special sphere, where the forces operative are "free," and their behavior not constant or "subject to necessity" as is that of stones and planets, fishes, birds, and beasts. But the view taken here considers moral laws to be of the same character as natural laws. They express the invariable sequence of acts and effects. Lying, theft, murder, adultery, and incest are detrimental to the maintenance and strength of human life. The laws are often very difficult to discover, since the forces are partly psychical and the complexity is so great. A thousand lines of antecedents and consequents are blended together in almost every act. To separate and trace the lines is no easy task. On many important matters opinion still differs. But law reigns; and it will be a fortunate day for ethical science when there is general recognition that human action is subject to the same uniformity, 
regularity, or causal relation of antecedent and consequent, as is the behavior of physical bodies, chemical agents, plants, and animals.

It will be seen that moral laws are thus understood to be phases of natural law. The various attempts of man to discover and to formulate them are analogous to his attempts to discover and to formulate other natural laws. The principles governing the variations between offspring and parents are not yet known and stated. What laws regulate the differences in a litter of puppies? The parents are the same, and the conditions apparently alike. There are thousands of such things not yet understood and explained. Few of us doubt the reign of law there, however, and if any one wishes to operate in this realm he first undertakes to understand the laws, and then acts accordingly. A horse breeder or a dog breeder who wishes to secure products with certain characteristics selects and mates individuals possessing those traits, and continues the process among their offspring. Moral laws are of similar nature. There are many occurrences in human conduct which are difficult to reduce to rule. The sequence of causes and effects cannot be discovered. Of two men with the same parentage, the same infancy, the same youthful training, the same college education, why should one be noble and the other base? The moralist is unable to account for their unlikeness, just as the biologist cannot yet explain the differences in the litter of puppies; but he has no more right to claim "freedom" or exemption from the operation of law for these two sons than the biologist has to offer "freedom" as the explanation (or, better, 
"cloak for ignorance") of the variations among the puppies. Law reigns in both instances, even though difficult to trace. And, really, men believe this. In actual life they act upon the conviction that determinate consequences follow determinate causes. Otherwise why should they lay any importance upon care in marriage, avoidance of imbecility, insanity, and epilepsy, or upon the surroundings of childhood, the education of youth, and the purification of the social environment? Man's behavior is subject to law the same as anything else. A moral act is a "natural" phenomenon as truly as is the mating or migrating of birds; and to inquire for causes and effects is as appropriate in the one case as in the other.

A correct moral law would be like an accurate physical or biological law, and would express the constant relation of cause and effect; only, in this case the objects spoken of are human social beings and their conduct. Moral laws have their foundation in the nature of things, in the causal connections between actions and their effects upon life. The reason that perjury and theft ought not to be is because they cannot be without damage. These things can occur only as "variations," "freaks," or "exceptions," just as such happen in the realm of biology. Incest is a moral monstrosity, exactly as a calf with two heads or five legs is a biological monstrosity. The conditions of physical life being what they are, the possession of two heads or five legs by a calf is detrimental and unusual. The conditions of moral life being such as they are, the commission of incest is pernicious and abnormal. 
The causal relation between antecedent and consequent lies back of moral laws as truly as of any other natural laws. If there were no regular connection between acts and their effects upon the actor and his environment, there would be no moral laws. A moral law expresses the natural regularity between an act and its consequences for human life.

The objection may be raised, Natural laws operate without exception; masses always move according to the law of gravitation; but human beings do not always act in the same way; in fact, they behave hardly ever twice alike. Moral law says "Thou shalt not steal," but men do steal. Moral law demands, "Thou shalt not commit adultery," but men do commit adultery. Natural law does not command a stone or a man, "Thou shalt not fall away from the earth's centre." Natural law describes what always occurs; moral law prescribes what ought to be done; there are no exceptions to natural laws; exceptions are almost the rule to moral laws.

Is this objection valid? There are apparent deviations from natural laws." Cloth "ought" to gravitate toward the earth's centre; but when made into a balloon and inflated with gas it rises instead. Water "ought" to sink; but in a bottle that contains both water and mercury it rises. The exceptions to moral laws are also only apparent. This

${ }^{2}$ Mill gives an excellent overthrow of "the popular prejudice that all general truths have exceptions." "Rough generalizations suggested by common observation usually have exceptions; but principles of science, or, in other words, laws of causation, have not." The "exception" to a "rule" is itself in accordance with law. "There are not a law and an exception to that law, the law acting in ninety-nine cases, and the exception in one. There are two laws." For full discussion, see Mill, "Logic," book III, ch»p. 10, p. 293. 
man "ought" to be kind; but a pampered infancy, youthful indulgences, brutalizing employment and surroundings have made him cruel. That man "ought" to respect human life; but a diseased physical constitution, hereditary mental propensities from degenerate grandparents, an insane mother, and a syphilitic father, together with the influences of a neglected childhood, evil surroundings and training have made him a murderer.

It is commonly said with the utmost confidence, even by moral philosophers, that natural laws and moral laws are different in that a natural law cannot be violated while a moral law can. The moral law says "Thou shalt," but the natural law says "Thou must." For example, you cannot transgress the law of gravitation, but you can transgress the law of truthfulness; you unceasingly tend toward the centre of the earth, but you are not always truthful. What shall we reply to this? The contention is false. The moral law is wrongly expressed when thus juggled with. The law of gravitation is stated correctly, but the law of truthfulness is stated incorrectly: the general law of gravitation is set in comparison with a specific and conditional application of the law of truthfulness. A statement of the law of gravitation comparable to the moral law of truthfulness "Thou shalt not lie" would be, "Thou shalt not jump from a precipice." A statement of the law of truthfulness comparable to the law of gravitation "All terrestrial masses tend toward the centre of the earth" would be, "Lying tends to the diminution and destruction of human life." These philosophers show that one can disobey the imperative "Thou 
shalt not lie" (either an arbitrary "unconditional categorical dictate," or at most, a particular and conditional application of a moral law), but they do not prove that one can violate the moral law "Lying tends to the diminution or destruction of human life," which alone may correctly be set in comparison with the natural law of gravitation. A man may disregard the moral law of truthfulness by telling a lie and bearing the results; but just as truly he may act in defiance of the natural law of gravitation by throwing himself from a precipice and suffering the effects. The consequences are sure in both cases; and neither law is "violated" any more than the other. I accept without investigation that both these laws have been discovered to be real principles, instead of hypotheses. As examples they show that a moral law is like any other natural law so far as regards the possibility of violation.

It is unfortunate that the practical moral proscriptions "Thou shalt" and "Thou shalt not" pass current as moral laws. They are as absurd expressions of moral laws as "Thou shalt not bathe thy face in sulphuric acid" and "Thou shalt not jump from a precipice" are ridiculous as statements of chemical and physical laws. All such recommendations are merely practical applications to specific cases.

We may add a word concerning the other so-called normative sciences, merely to say that neither are they "normative" in the sense of being essentially different from the so-called "historical" and "descriptive" sciences. "Grammar tells us how men ought to speak," "Logic tells us how men ought to reason." These are more correctly expressed if we 
say "Grammar tells us how men must speak if they are to have intercourse with one another and understand one another," "Logic tells us how men must reason, if they are to avoid error and contradiction in their reasoning"; or, more briefly stated, "Ungrammatical speech tends toward unintelligibility and personal isolation," "Illogical reasoning tends toward contradiction and confusion of thought." If these are real laws, they cannot be "violated" any more than the natural law of gravitation. One can "violate" a special rule or specific practical application, like "You ought not to use double negatives," just as one can set at naught a specific practical application of the law of gravitation, like "You ought not to jump from a precipice." Even the State's laws, originating apparently in the arbitrary wills of men, are based in the last analysis upon natural laws, upon the causal relations existing between modes of human conduct and their effects upon life. Legal ordinances owe their origin to the fact that the prohibited acts have injurious effects upon society. Thus even statutory law is grounded in natural law. 


\section{CHAPTER XVII}

\section{TRANSCENDENTAL FREEDOM}

SEтH, in acknowledging the "difficulties" which the free-will theory encounters, says: "Recognizing these difficulties, and regarding them as insuperable, we may still accept freedom as the ethical postulate, as the hypothesis, itself inexplicable, upon which alone morality becomes intelligible. This is the 'moral method,' which some living thinkers share with Kant." 1

For Kant and his disciples freedom is not in the world of phenomena; it is in the world of "'noumena." They admit that in the realm of phenomena there is no freedom, but everything acts in accordance with the laws of causation. They assert, however, that freedom exists in a transcendental universe, a sphere above the limitations of sense, space, time, and causation.

No one of these persons has accomplished his aim of demonstrating either the reality of this freedom or the necessity of postulating it. He may claim to have transcended phenomena and the relations of space, time, and causation; but as a matter of fact these things continue to exist in his system in some form or other. He merely doubles the facts that need to be explained; or else he denies their "reality." But to account for the world either by doubling it or by denying it is not satisfactory.

$$
{ }^{1} \text { Seth, op. cit., pp. } 366 \text { ff. }
$$


But I amnot inclined to enter on argument concerning the existence or non-existence of transcendental freedom. I am interested only in the present world, the world of matter and sense, of space, time, and causation, the world of life and action, of love and hatred, of social good and social evil, of human suffering and human joy, the earth. About a transcendental universe, a realm of "thing-in-themselves", "noumena," of existences of pure intelligence, - a heaven or hell or Nirvana, - I am not in the least concerned. If the advocates of free-will admit determinism in "the world of phenomena," they may claim "freedom" in the "world of noumena." If the free-willist flees for refuge to that distant and doubtful sphere of the noumena, he deserves the right of sanctuary and exemption from attack by science. Science or determinism (the same thing) can lay down arms and enjoy the peace of the land.

The free-willist first tries to establish free-will behind each action. Then he endeavors to place it behind a whole series of actions, or behind the character. Driven to the extreme, he locates it in a transcendental world. There, however, we will leave him alone, with his lifeless images of the dead. 



\title{
PART III \\ RESPONSIBILITY FOR CRIME
}

\author{
CHAPTER XVIII
}

\section{EARLY EXTREMES AND PRESENT PRACTICES}

AcCording to the theory of determinism, acts follow of necessity from what has gone before. Then how can it be just that a man should be punished for deeds which could not have been different? The ideas of crime and freedom are inseparable from the idea of responsibility. We must therefore examine this aspect of the problem.

The conception of responsibility has undergone extensive evolution in the history of the various peoples of the world. In primitive times, and among savage tribes at the present day, practically all persons, and even things, are held accountable. Everything is considered to be animated; and anything that does injury comes under disapprobation and penalty. Even in civilized Athens there existed the practice of holding inanimate objects liable. The following regulation was prescribed by Plato in his "Laws": - "If any lifeless thing deprive a man of life, except in the case of a thunderbolt or other fatal dart sent from the gods, - whether a man is killed by lifeless objects falling upon him, or by his falling upon them, the nearest of kin shall appoint the 
nearest neighbor to be a judge, and thereby acquit himself and the whole family of guilt. And he shall cast forth the guilty thing beyond the border." 1

Xerxes caused the Hellespont to be beaten with three hundred lashes because it would not obey his commands; and Cyrus "wreaked his vengeance" on the river Cnydos by dispersing it through three hundred and sixty channels. ${ }^{2}$

The practice of blood revenge was often extended to the animal world. It was the custom of certain Asiatic and African tribes that if a tiger killed some one, the family of the victim was obligated to revenge his death by the death of the tiger. Again, an alligator was never slain unless it had killed some one; in which case, its death was demanded. The inhabitants made yearly proclamation to the crocodiles, warning them that the death of friends would be revenged, and admonishing the well-disposed crocodiles to keep out of the way, as the quarrel was not with them but only with their evil-minded relatives. ${ }^{3}$

Animals were not only exposed to the blood-feud, but often to regular punishment. "According to Hebrew law, "if an ox gore a man or a woman, that they die: then the ox shall be surely stoned, and his flesh shall not be eaten.' . . . Plato had undoubtedly borrowed from Attic custom or law the idea which underlies the following regulation in his 'Laws'; 'If a beast of burden or other animal cause the death of any one, except in the case of anything of that kind happening to a competitor in the public contests, the

1 Plato, "Laws," ix, 873 ff.

${ }^{2}$ Cf. Herodotus, vii, 35; i, 190.

'Cf. Westermarck, op. cit., vol. I, pp. 252, 253. 
kinsmen of the deceased shall prosecute the slayer for murder, and the wardens of the country, such, and so many as the kinsmen appoint, shall try the cause, and let the beast when condemned be slain by them, and let them cast it beyond the borders. In various European countries animals have been judicially sentenced to death, and publicly executed, in retribution for injuries inflicted by them. Advocates were assigned to defend the accused animals, and the whole proceedings, trial, sentence, and execution, were conducted with all the strictest formalities of justice. These proceedings seem to have been particularly common from the end of the thirteenth till the seventeenth century; the last case in France occurred as late as 1845. Not only domestic animals, but even wild ones, were thus put on trial. . . . There has been considerable diversity of opinion concerning the purpose of inflicting punishments upon animals. ... But the true solution of the problem seems simple enough. The animal had to suffer on account of the indignation it aroused. It was regarded as responsible for its deed. In early records the punishment is frequently spoken of as an act of 'justice'. . . . From certain details we can also see how closely the responsibility ascribed to animals resembled the responsibility of men. In some of the texts of the Salic law the animal is spoken of as 'auctor criminis.' . . . Youth was a ground for acquittal, as appears from a case which occurred at Lavegny in 1457, when a sow and her six young ones were tried on a charge of their having murdered and partly eaten a child: whilst the sow, being found guilty, was condemned to death, the young pigs were 
acquitted on account of their youth and the bad example of their mother. In Burgundy, a distinction was made between a mischievous dog that entered a room through an open door and one that committed a burglary; the latter was a larron and was to be punished as such. The repetition of a crime aggravated the punishment. And the animal 'principal' was punished more severely than the 'accessories." " 1

Lunatics and insane people were also considered responsible, and were punished accordingly. "In none of the German town-laws before the beginning of the seventeenth century is there any special provision for the offences of lunatics. . . . In Germany recognized idiots and madmen were not seldom punished with great severity, and even with death, in the seventeenth and eighteenth centuries. One of the darkest pages in the history of European civilization may be filled with a description of the sufferings which were inflicted upon those miserable beings up to quite modern times. Many of them were burnt as witches or heretics, or treated as ordinary criminals. For unruly and crazy people, who nowadays would be comfortably located in an asylum, whipping-posts and stocks were made use of. . . . The writings of Esquirol, the parliamentary debates on the asylums of Bedlam and York, and the reports presented under the auspices of La Rochefoucauld to the National Assembly of 1789 , contain a picture unique in its sadness - 'a picture of prisons in which lunatics, criminal lunatics, and criminals are huddled together indiscriminately without regard to sex or age, of

$$
\text { 'Ibid., vol. I, pp. 253-258. }
$$


asylums in which the maniac, to whom motion is an imperious necessity, is chained in the same cell with the victim of melancholia whom his ravings soon goad into furious madness, and of hospitals in which the epileptic, the scrofulous, the paralytic and the insane sleep side by side, - a picture of cells, dark, foul, and damp, with starving, diseased, and naked inmates, flogged into submission, or teased into fury for the sport of idle spectators.'

Thousands of persons were put to death on charges of magic, sorcery, witchcraft, and other crimes as unreal as these. The only shortcomings of these poor beings were those of having a disordered nervous system and of living in a time of profound ignorance. ${ }^{2}$

Little or no account was taken of circumstances, or of the agent's character as inferred from past behavior, or of his real intention. Only slight, if any, distinction was made between the good and evil which an individual meant to do and that which he happened to do. The working presumption of society, up to a comparatively late stage of its history, was that every harmful consequence was an evidence of evil disposition in those who brought it about. Only gradually did intent clearly evolve as an important element in an act, and influence judgments of liability. ${ }^{3}$

Responsibility and punishment were not limited to the criminal. Family, relatives, friends, and even all the members of the culprit's tribe were sometimes held liable. The strict limitation of accounta-

Westermarck, op. cit., vol. I, pp. 273, 274.

'Cf. Hamon, op. cit., p. 137.

${ }^{8}$ Cf. Dewey and Tufts, op. cit., pp. 459, 460. 
bility to the author of a crime is not even yet fully accomplished. A vestige of these antique theories is still seen in the army, where it is sometimes the practice to punish a company, a battalion, or an entire regiment, for the fault of some individuals. Collective responsibility survives still in the relations between nations. Thus an entire country is answerable for an act committed by one of its members in certain cases, especially by a soldier. International war is sometimes the result of this responsibility.

The present attitude of criminal law toward responsibility may be epitomized from Kenny's "Outlines of Criminal Law":

No external conduct, however serious or even fatal its consequences may have been, is ever punished unless it has been produced by some form or other of mens rea. . . . In all ordinary crimes the psychological element which is thus indispensable may be fairly accurately summed as consisting simply in "intending to do what you know to be criminal." It admits, however, of a minuter description. Thus, in the scientific analysis given by Professor E. C. Clark, it is shown to require:-

(1) The power of volition; i. e., the offender must be able to "help doing" what he does. This faculty is absent in persons who are asleep, or are subject to physical compulsion or to duress by threats, or whose conduct is due to accident or ignorance; and it is also absent in some cases of insanity, of drunkenness, and of infancy. Where it is absent, an immunity from criminal punishment will consequently arise.

(2) Knowledge that what the offender is doing is criminal; either intrinsically, or, at any rate, in prospect of such consequence as he has grounds for foreseeing. There will be an absence of such knowledge in very early infancy, or in the case

${ }^{2} C f$. Bayet, "La morale scientifique," p. 146; Hamon, op. cit., p. 121. 
of some delusions as to the supernatural; and immunity, accordingly, will arise.

(3) In such crimes as consist of conduct that is not intrinsically unlawful, but becomes criminal only when certain consequences ensue, there must further be the power of foreseeing these consequences. . . . The power of foresight may be absent in infancy, even in late infancy; and in some forms of insanity. . . . In most cases the law regards the criminal act itself as sufficient prima facie proof of the presence of this mens rea. Every sane adult is presumed to intend the natural consequences of his conduct. . . .

Mens rea, in some shape or other, is a necessary element in every criminal offence. If this element be absent, the commission of an actus reus produces no criminal responsibility.

Blackstone's classification of the various conditions which in point of law negative the presence of a guilty mind, has become so familiar that it is convenient to adhere to it, in spite of the defects of its psychology. Three of his groups of cases of exemption deserve minute consideration. 'These are: I. Where there is no will. II. Where the will is not directed to the deed. III. Where the will is overborne by compulsion.

I. Where there is no will. . . . absence of will may be due to any one of various causes. (1) Infancy. . . . There is a conclusive presumption that young children cannot have mens rea at all. Nothing, therefore, that they can do can make them liable to be punished by a criminal court. . . (2) Insanity. Absence of "will" may also arise ... from a morbid condition of mind. . . The law has never held, as a widespread popular error imagines it to hold, that the mere existence of insanity is of itself necessarily sufficient to exempt the insane person from criminal responsibility. Only insanity of a particular and appropriate kind will produce any exemptive effect. For lunatics are usually capable of being influenced by ordinary motives, such as the prospect of punishment; they usually plan their crimes with care, and take means to avoid detection. . . . They are quite capable of taking into account the chances of being or not being punished. . . . The world, it is now recognized, is full of 
men and women in whom there exists some taint of insanity, but who nevertheless are readily influenced by the ordinary hopes and fears which control the conduct of ordinary people. To place such persons beyond the reach of the fears which criminal law inspires,. . . would be an actual cause of danger to the lives and property of all their neighbors. Where insanity takes any such form, it comes clearly within the rule of criminal legislation propounded by Bain: "If it is expedient to place restrictions upon the conduct of sentient beings, and if the threatening of pain operates to arrest such conduct, the case for punishment is made out."

The law therefore divides, and would seem to be fully justified in dividing, insane persons into two classes:- (a) Those lunatics over whom the threats and prohibition of the criminal law would exercise no control, and on whom therefore it would be gratuitous cruelty to inflict its punishments; and (b) Those whose form of insanity is only such that, to use Lord Bramwell's apt test, " they would not have yielded to their insanity if a policeman had been at their elbow." But the very difficult practical question as to where the line of demarcation should be drawn between the two classes, is one upon which the views of English judges have undergone grave though gradual changes, and even now cannot be said to have developed into a complete or even a perfectly stable form. ... The rule broadly stated is or at least should be this, "that no act is a crime if the person who does it is at the time when it is done prevented, either by defective mental power or disease affecting the mind, from controlling his own conduct, unless the absence of the power of control has been produced by his own default. ..."

(3) Intoxication. Drunkenness is ordinarily no excuse for the commission of a criminal act; even though it have produced for the time as great an aberration of mind as would, if caused by insanity, constitute a legal exemption from responsibility. For, closely akin though it is to a temporary insanity, it differs from it by having been produced voluntarily. And to produce it, is morally wrong, and even a criminal offence. . . . It is thus a madness for which the madman is to blame. . . . If, however, a man's habits of 
drinking have resulted in rendering him truly insane, his insanity, even though caused thus, will have just the same effect in exempting him from criminal responsibility as if his madness had not been so brought on by his own voluntary misconduct. Thus it has been held by Stephen, J., that where delirium tremens caused by drink produces, although only temporarily, such a degree of madness as to render a person incapable of distinguishing right from wrong, he will not be criminally responsible for acts done by him while under its influence. Occasionally, however, instances arise of a drunkenness to which no moral blame attaches; for example, where it has been produced by the contrivance of malicious companions, or by the administration of alcohol for adequate medical reasons. So also where there was an exceptional susceptibility to stimulants of which the person was not aware and he became drunk by taking a moderate quantity of spirits. It will be no defence, however, for the person to say that he did not intend to get drunk. In these rare cases, an actus reus committed by the intoxicated man may involve him in no punishment; since it has been preceded by no mens rea, neither the usual immediate one, nor even the remote one of voluntarily getting drunk. . . .

II. Where the will is not directed to the deed. We may fairly regard this state of mind as always arising from mistake or some other form of ignorance (e.g. taking from the hat-stand in your club another man's umbrella in mistake for your own). ... Our criminal law often allows mistake or ignorance to afford a good defence by showing, even where there has been an actus reus, that no sufficient mens rea preceded it. But such a defence can only arise when three conditions are fulfilled. (1) The mistake must be of such a character that, had the supposed circumstances been real, they would have prevented any guilt from attaching to the person in doing what he did. . . . It will be no offence to lay violent hands upon a person whom you reasonably, though mistakenly, suppose to be committing a burglary. ... (2) The mistake must be a reasonable one. This will be mainly a question of fact. The jury, assisted by the judge's directions, must determine the reasonableness of the mistake, that is, whether the prisoner's 
conduct was what would be expected of the man of ordinary caution and prudence under like circumstances. ... (3) The mistake, however reasonable, must not relate to matters of law but to matters of fact. For a mistake of law, even though inevitable, is not allowed to afford any excuse for crime. . . .

III. Where the will is overborne by compulsion. (1) Public civil subjection . . . will occasionally constitute a defence. Thus when violence is exercised by a jailer or hangman in carrying out an invalid sentence. . . (2) Private civil subjection ... only in the case of conjugal subjection, ever amounts to a defence. For if a wife commits any ordinary crime in her husband's actual presence and by his instructions, she is regarded by the law as having committed it under such a compulsion as to entitle her to be acquitted. . . (3) $\mathrm{Ne}$ cessity. The fact that a man who has inflicted harm upon another's person or property did so for the purpose of warding off from himself some much greater harm, has from early times been recognized as a defence in civil actions, brought to recover compensation for the harm thus inflicted."

"Kenny, "Outlines of Criminal Law," American edition, chaps. III and IV, "The Mental Element in Crime," and "Exemptions from Responsibility," pp. 35-71. 


\section{CHAPTER XIX}

\section{ARGUMENTS FOR COMPLETE IRRESPONSI-}

\section{BILITY OF ALL CRIMINALS}

Schopenhader called "the hardest of all problems" the following: "How is it that there is such an enormous difference between one character and another? - the malicious, diabolical wickedness of the one, and set off against it, the goodness of the other, showing all the more conspicuously. How is it that we get a Tiberius, a Caligula, a Caracalla, a Domitian, a Nero; and on the other hand, the Antonines, Titus, Hadrian, Nerva? How is it that among the animals, nay, in the higher species, in individual animals, there is a like difference? - the malignity of the cat most strongly developed in the tiger; the spite of the monkey; on the other hand, goodness, fidelity, and love in the dog and the elephant. It is obvious that the principle of wickedness in the brute is the same as in man." 1 A scientifically trained person would hardly answer this question by asserting either that the difference is due to chance or that it is due to "freedom of choice" on the part of the individuals (the selection would but express an already existing goodness or badness).

The person who denies responsibility says, The criminal is not responsible for his act. It is the inevitable result of determinate motives acting upon ${ }^{2}$ Schopenhauer, "On Human Nature," p. 100. 
a certain mental disposition. Throughout the whole series, necessity rules. Nothing could be different from what it is. His mentality is the work of necessity. The motives that affect it are unalterably occasioned. The criminal is not personally responsible. You must search farther back for the causes of his acts. He is only the intermediary in the accomplishment of his deeds. We should no more condemn a bad man than a poisonous plant.

There is really no culpability or moral blameworthiness on the part of wrongdoers. In criminals we must see only creatures of misfortune, sick people, persons damned by heredity or anatomical predestination, victims of mental obsessions and nervous disorganizations. The bond between the physical and the mental is seen by physiologists and psychologists to be very close. The notion of culpability must disappear from society as scientifically unsound. ${ }^{1}$

Crime is the effect of physical, anthropological, and social conditions acting simultaneously and inseparably to determine the act. Notice briefly the determining influence of each of these factors.

The will is subjected to the influences of physical agents. Volitional energy is considerably affected by influences of the natural environment. It varies in each individual under the influence of heat, cold, storm, humidity, dryness, electric condition of the atmosphere, light, climate, altitude, geology, vegetation. It is dependent on the nutrition of the brain, which in turn is connected with the conditions of the nourishing liquid, the blood, -- its composition and

${ }^{1} C f$. Tarde, "Études pénales et sociales," essai sur "L'idée de culpabilite," p. 321. 
circulation. Every cause which increases or diminishes the pressure of the blood, modifies the will. Alcohol, coffee, tea, tobacco, opium, morphine, are such causes. Absence of sunlight provokes anæmia and tuberculosis, and depresses the nervous system. Excessive light is a powerful excitant which may alter the nervous system. The same person has not the same will in the light as in the dark, other things being equal. Willing is affected also by heat and cold. The blood-vessels expand or contract; the pulse beats fast or slow; the brain is bathed in blood that is changed more or less rapidly. The same is true with reference to the air breathed;-its composition, pressure, humidity, and electric state all modify the circulation and chemical properties of the blood. The brain is nourished by a liquid of varying composition and of diverse rates of circulation. Consequently, volition, a function of the brain, varies according to the nutrition of that organ.

Criminal volitions sometimes result from anthropological or individual abnormalities. Moral and intellectual irregularities may be caused by physiological disturbances in digestion and assimilation, by diabetes, gravel, retention of urine, gout, rheumatism, excessive fatigue. Every physiological condition influences the vigor and rapidity of the mental processes, and consequently, of the will. It produces either a state of nervous vigor or a state of nervous depression. This last state may proceed to complete absence of volition. Will may be extinguished the same as memory, intelligence, or any other function of the central nervous system. We all know how ${ }^{\prime}$ Cf. Hamon, op. cit., pp. 31-34. 
our wills are affected by difficult digestion. The brain is less nourished, the blood going to the stomach, which has the greatest need of it at this time. The manner in which food is assimilated plays a part in influencing the will. The abnormal accumulation of toxins in the organism exercises a powerful disturbance upon the functions of the nervous system. This action is variable in its intensity and in its manifestations according to the duration of the action of the toxins and the greater or less resistance of the organism. ${ }^{1}$

In many cases, at least, crime must be considered the result of some form of mental derangement. Lunacy was, for a very long time, not regarded as affording immunity from punishment. Many judges, even, maintained that insanity could not lessen responsibility unless the criminals were totally unable to distinguish between right and wrong at the moment when their misdeeds were committed. The work of Maudsley and more recent students of abnormal psychology has led to the general recognition, among people of reflection, that crime is, in numerous instances, the direct result of mental alienation or dissolution. The logical test of insanity, "not knowing the difference between right and wrong," is simply absurd. The lunatic may know the distinction as well as any one else. Besides, the medical world has long since given up the idea of a sharp line of division between the sane and the insane. At what degree do indecision, irritability, sorrow, and emotional disturbances pass over into mental abnormality? We all have our periods of indecision; but we send a per-

$$
{ }^{2} \text { Cf. ibid., pp. 35, 39, } 161 .
$$


son to a physician if he passes hours in agonizing perplexity without being able to decide whether to change his shirt to-day or to-morrow. It seems normal to us to be sad upon the loss of a dear friend, and to be discouraged over failures; but we regard anybody as diseased who commits suicide in order to escape the perplexities to which we are all subjected. ${ }^{1} \quad$ There are innumerable stages between the absolutely normal and the absolutely insane. The lunacy of many criminals is not recognized at the time of their conviction, but only later on. Prison statistics show that the proportion of prisoners who are adjudged insane is very large, and that the proportion of prisoners who come of demented or epileptic parents is still many times larger.

Now it is absurd to believe that only those criminals who are wholly insane are necessitated to their crimes by their affliction. Every kind of mental weakness or derangement supplies its quota of crime. Man's action is certainly conditioned in large part by his material organism. Faults of character depend frequently upon physiological accidents. The disposition of a person may be totally changed by even a slight injury to the brain, or by habitual use of drugs and alcohol, or by disease that becomes chronic. A little softening of a square inch of the cortex may make a man a kleptomaniac, while a small patch of inflammation in the brain may give one homicidal tendencies. ${ }^{2}$ Do such persons nevertheless have a "freedom of the will" that makes them responsible for their actions?

${ }^{1}$ Cf. DuBois, op. cit., p. 67.

2Cf. Hollander, "Crime and Responsibility." 
We cannot rightly expect or demand common-sense and normal morality from these deficient beings. The criminal is mentally and morally defective. It is unreasonable to punish him; he is not responsible. We must all recognize the fact that many an offender is a born criminal, whose physical and psychical proclivities lead inevitably to crime. Certain truths like these simply have to be admitted, no matter how much they conflict with prejudices and pet dogmas about freedom of the will. It is obvious to anybody that there are criminals who, by heredity, are predisposed to crime, - individuals whose selfish tendencies predominate over altruistic motives, and whose abnormal mentality will lead them into wrong-doing as soon as propitious circumstances present themselves.

Basing their investigations on anthropology, medical science, psychology, and psychiatry, criminologists have called to our attention the fact that very many criminals have abnormalities in the structure and development of the brain. There are anomalies in the tissue, in the convolutions, and in the development of the various parts of the brain, together with irregularities in the cranial cavity. Criminality is often found to be related to atavism, to arrested growth of the brain, to disease of the tissue, to epilepsy, and to degeneracy. Is it possible that people afflicted with great malformations and alterations of the brain should have the same sentiments as men with brains entirely normal?

In setting forth the different kinds of insane criminals, Ferri said that this category includes all the intermediary types between complete madness and 
a rational condition. These offenders are the perpetrators of terrible crimes without motive, attacks upon persons in authority, sexual outrages, purposeless destruction of property, and similar atrocious deeds. ${ }^{1}$ In describing the "born or instinctive criminals," he said that they are the ones who most frequently present the organic and physiological characteristics established by criminal anthropology; they are either savage and brutal, or crafty and lazy; they draw no distinction between homicide, robbery, and other crimes, on the one hand, and honest industry, on the other; they are not at all affected by punishment, but regard it as an ordinary risk of their occupation; they are the natural recidivists, returning to prison again and again, with a frequency depending entirely upon the brevity of the separate incarcerations and the quickness of capture after each return to crime; they are the delinquents who illustrate most clearly the folly of the legislators who persist in permitting this continual round of inefficacious punishments and repeated crimes. ${ }^{2}$

It seems, also, from the discoveries of abnormal psychology, that exemption should be accorded to those affections which, like hystero-mania and neurasthenia, have been called the borderland of insanity. The modern science of psychiatry is leading people to recognize that in addition to that familiar kind of aberration which impairs a man's judgment, there are other and subtler forms which affect his will, either by weakening his natural inclinations or by inspiring abnormal impulses. These may be

'Cf. Ferri, op. cit., pp. 27, 28.

${ }^{2}$ Cf. ibid., pp. 28-30. 
called "affective" types, to distinguish them from the better known "intellectual" types of insanity."

Ever since Lombroso called attention to the anthropological similarities between criminals and degenerates and neurotics, there has been a steadily growing recognition of the kinship between these abnormal forms. We have no hesitation in adopting stringent measures against delinquents, because they are so obviously anti-social. But in the case of degenerates and neurotics, we are less certain that they are anti-social, and hence we are less severe. We do not know how to deal with them, whether to handle them roughly or to care for them tenderly in an infirmary. The question comes up imperatively, however, in the frequent cases where these abnormal persons come into conflict with justice by committing offences against the public order, acts of violence, and even murder.

The present legal practice distinguishes between complete irresponsibility and partial responsibility. It holds many insane persons responsible for their acts, believing that their insanity affects only a certain part of their mental life. It seems to regard the individual's cerebral apparatus as divided into two sharply distinct departments, the one wholly sane, the other wholly insane. It attempts to decide whether a particular act derives its origin from the sane or from the insane portion of consciousness. Those acts which show reflection, long deliberation, and careful planning are judged to proceed from the sane part; those which are impulsive or purposeless, from the insane part. The effort is to prove that ${ }^{1}$ Cf. Kenny, op. cit., p. 53. 
such and such a criminal act proceeded not from the insane part, but from the sane part, and consequently entails responsibility. Such an endeavor is an attempt to show that a crime was an act of good sense on the part of the insane person! All this is a false procedure. It is absolutely impossible to show that insanity affects one part of life or one line of behavior or one set of relations, but has no influence upon any other matters. It is impossible to prove that insanity along one line of ideas or one line of action does not react upon all the mental and volitional life of the person afflicted. It is an error to think that a person is not completely insane if some of his conceptions and acts agree with facts and show intelligence, deliberation, and purpose. If any one is proved insane in certain aspects, his insanity exempts him from responsibility not only in those aspects, but in all. There is no such thing as partial responsibility or attenuated responsibility. Who can show that a brain insane in some of its parts nevertheless functions in its other parts in the way it would function if it were wholly sane? ${ }^{1}$

Epileptics should be considered to be absolutely exempt from responsibility. With an epileptic a convulsive attack may be replaced by an attack of acute insanity, under the sway of which the afflicted person may kill, with total lack of attention or intention, the first person who comes in his way, and may then recount his crime with as little concern as though it were the most insignificant act in the world. The epileptic is absolutely irresponsible; because his malady arises from a brain in which there ${ }^{1}$ Cf. Hamon, op. cit., pp. 184-188. 
are certain anatomical lesions which produce a mental state that is profoundly defective and disordered. ${ }^{1}$

A person is not an indivisible unity. Investigators in abnormal psychology tell us of many cases where there exist several distinct personalities in one individual. Such individuals have a plurality of memories, a plurality of consciousnesses, a plurality of wills, - the phenomena of each of the personalities being distinct from the phenomena of the others. Each personality is ignorant of what goes on in the others. ${ }^{2}$ Such abnormal beings cannot be held accountable.

Another set of persons who are completely irresponsible are those under the obsession of "fixed ideas." An idea implants itself in the mind, dominates all others, overmasters all functions of the mind and directs them toward the realization of this all-powerful and violent idea. Any crime may easily be committed in this condition; because no other idea can originate or develop sufficiently to inhibit action. Many crimes have been committed by persons under the domination of some one idea which overrode anything and everything that stood in the way of its accomplishment. Such persons are not answerable for their acts. ${ }^{3}$

Responsibility cannot be attributed in those cases where a crime has been committed under the lead of an excessively preposterous motive. There are instances of the sway of a perfectly ridiculous motive, showing clearly some mental derangement. A man

${ }^{1}$ Cf. ibid., pp. 153, 154.

${ }^{2} C f$. Ribot, "Les maladies de la personnalite," "Les maladies de la mémoire," "Les maladies de la volonté."

'Cf. Hamon, op. cit., p. 155. 
killed his room-mate because he snored too loudly. A gentleman of wealth killed his daughter because she was growing so large as to occasion increased expenditure for clothes. A servant girl poisoned some children in order to have an occasion to go out on the street on the way to the physician and the drugstore. A devoted mother, under pressure of poverty, drowned her two children "because it was the best thing she could do for them." The absurdity and folly of the motives in such cases as these prove dementia and irresponsibility. ${ }^{1}$

Accountability cannot attach to those persons who commit crimes in a fit of passion, or as the result of an emotion so sudden and violent that the best intention in the world would be powerless against it. Further, alcoholism must be considered in general as a physiological defect, removing liability. Accumulating evidence is leading scientists more and more to regard the alcoholic, especially the hereditary alcoholic, as a diseased person, and, on account of his malady, predisposed to crime, and irresponsible. ${ }^{2}$ When we think of the proportion of crime chargeable to alcoholism, we realize how large a part of crime will be declared exempt from liability when alcoholism is regarded as nullifying responsibility.

${ }^{1}$ Cf. Hamon, op. cit., pp. 158, 159; Kenny, op. cit., p. 51.

"See Reid, "Alcoholism; a Study in Heredity." This book is an application of the Weismann doctrine of heredity to the facts of alcoholism. There is no hope for temperance reform through the abolition of drink; the only hope is through the elimination of the drunkard. Every race is temperate strictly in proportion to its past sufferings through alcohol. Alcoholism will have to be eradicated from human nature through the regular ways of selection, natural and artificial. Natural selection is working against alcoholism ... "the fittest to survive" are the temperate. Men can assist the process through selective mating. 
There are also certain pathological conditions connected with sex which induce extraordinary conduct and nullify the responsibility therefor. Science has proved certain mental troubles to be caused by puberty, menstruation, pregnancy, change of life, and by certain sexual abnormalities, perversions, and inversions. Everywhere now there are many persons considered irresponsible who would have been judged responsible a few decades ago. Before arriving at the present result, how many thousands of demented persons have been condemned and executed. ${ }^{1}$

It appears, then, that we must all admit that the sphere of responsibility is considerably restricted by these findings of criminal anthropology. Wherever action is determined by pathological conditions, there cannot be "freedom," "responsibility" and "punishment." Undoubtedly, the anthropological characteristics of many persons are such as to lead inevitably to wrong-doing. But these elements do not account for all the crimes committed. There are many offences which the criminal anthropologist cannot persuade us are due to some abnormality or anomaly in the constitution of the offender. Perhaps "responsibility" may take possession of these. The criminal anthropologist has driven it out of all that domain of crime which is ruled by the inexorable necessity of anatomical and physiological defectiveness in the transgressors. Possibly it may find a place of settlement elsewhere, and establish itself free from attack. We find, however, that this is not the case. The criminal sociologist comes to complete the work of destruction begun by the criminal anthropologist.

${ }^{1}$ Cf. Hamon, op. cit., pp. 142, 149, 150. 
He maintains that crimes not attributable to sources in the individual are to be assigned to causes in society. Social arrangements are productive of much wrong-doing. In fact, some sociologists maintain that these influences preponderate in the genesis of crime. They declare that the delinquent is the product of society. If this assertion be true, then of course "responsibility" must be charged not to the offender but to society. Lacassagne said that societies have the criminals they deserve. In other words, the number of criminals in any community is in direct proportion to the social forces that make for crime. A similar belief led Ferri to enunciate his famous "law of criminal saturation"- "Just as in a given volume of water, at a given temperature, we find a solution of a fixed quantity of any chemical substance, not an atom more or less, so in a given social environment, in certain defined physical conditions of the individual, we find the commission of a fixed number of crimes." 1 By this law Ferri meant to assert, not a mechanical regularity of crime, but a fixed proportion between a given environment and the number of crimes. The element of fixity consists, not in a fatal predestination of evil deeds, but in their necessary dependence upon their natural causes; and this implies the possibility of modifying effects by modifying the activity of the causes. ${ }^{2}$

The social factors of crime, according to Ferri, comprise "the density of population; public opinion, manners, and religion; family circumstances; the system of education; industrial pursuits; alcoholism; economic and political conditions; public adminis-

${ }^{1}$ Ferri, op. cit., p. 76. ${ }^{2}$ Cf. ibid., pp. 80, 81 . 
tration, justice, and police; and in general, legislative, civil, and penal institutions." 1

Tarde is a great champion of the sociological explanation of crime. The sovereigns of the kingdom of evil, according to him, ${ }^{2}$ are Imitation and Heredity, - the greater power in the production of crime being exercised by imitation. The nature of crime is explained by the nature of the mutual influence of persons grouped together. In an aggregation of men a psychological fermentation takes place. Social psychology is illuminating for an understanding of how the contagion of crime works. Criminals live together in groups, and imitate one another. They are influenced by mutual suggestion. From the individual of vicious character there goes out through the group a contagious propagation of evil influence. Suggestion and imitation are certainly very great forces in the propagation of crime in a community.

We realize, in some measure, at least, how social conditions lead to crime, when we reflect on our ineffective legal and judicial procedure, with its uncertainty, slowness, leniency, and short sentences; our faulty penal system, which places young offenders, first offenders, and petty offenders in the same institution with old and incorrigible criminals, thus making of the prison a veritable school of crime; our defective administration of relief to the destitute, and to the victims of accident, misfortune, and calamity; our inadequate educational system, which, by its lack of flexible adaptation to the various dispositions

Ibid., p. 53.

${ }^{2}$ Cf. Tarde, "Études pénales et sociales," pp. 268, 295-305. 
of its pupils, and its remoteness from the actual interests and needs of many of them, tends to drive them directly toward truancy and vagrancy; our corrupting political practices of bribery and graft; our savagely competitive régime of industry with its depressions and crises; our demoralizing domestic life in broken, incompetent, and vicious homes; our toleration of prostitution with its street solicitation; our open gambling resorts and gin palaces; our improperly conducted arrangements for receiving, distributing, and assimilating immigrants; our frightful overcrowding of the masses; our child-labor; our employment of pregnant women right up to the day of their delivery and again within a week of their confinement; our poverty that prevents education, trade training, and industrial opportunities; our hunger and misery that necessitate crime for the support of self and children; our sensational press, which acts as a stimulus to wrong-doing through the influences of suggestion and imitation, and sows the contagion of crime broadcast in society; our morbid literature, indecent shows, and immoral sports; our freedom in forming marriage unions among epileptic, feeble-minded, insane, scrofulous, and venereally diseased. In the light of such facts, who can doubt that society itself calls into existence beings without either physical or moral strength, people subject to uncontrollable whims and anti-social impulses?

We must surrender that old conception according to which men are divided, as it were essentially, into two classes: one the blameworthy and the other the meritorious. We must recognize that many crimi- 
nals are made such by the pressure of environment and education, of poverty and miserable living, of extraneous suggestion and stimulation. We must perceive that the evil character is often moulded by the influence of depraved surroundings. Under slightly different circumstances the offender might have been a decent member of society. The youth brought up in criminal surroundings takes to crime as naturally as a duck takes to the water. We must awake to the fact that the responsibility for wrong-doing ought to be attributed to those who failed to provide education in right-doing, and neglected to see that the temptations to crime were removed. ${ }^{1}$

Why hold the criminal liable? His act was the inevitable result of certain motives acting on a particular mental disposition. If you are seeking something to punish, you must look beyond his will, because it was determined by irresistible motives; beyond the motives, because they were made by desires, passions, physiological inheritance, education. The causes of the criminal's behavior lie back of him in his ancestors and in the environing society. The "responsibility" and the "punishment" for his deed must therefore be distributed among these sources. Society is itself to blame for a great part of crime. Instead of punishing the criminal, it ought to pity him. It has made him what he is. It should now take him and do the best it can to amend him, instead of wreaking vengeance upon him. Either the criminal is capable of being improved, in which case it is very doubtful that punishment is the best means

${ }^{1} C f$. Dewey and Tufts, op. cit., p. 469; Alexander, op. cit., p. 341. 
of accomplishing it, or else he is not susceptible to amendment, in which case it is senseless to administer corrective discipline, just as it is unreasonable to punish idiots and insane.

Society as a whole has largely contributed to create the criminal; and if fault there be we are all responsible. "Does it watch with sufficient love over the human nursery? Does it work with zeal to cure the sickly nurslings and to preserve the others from contagion? Evidently not. . . . Society ought to recognize more and more that if vicious people exist it is because it allows material, intellectual, and moral destitution to exist in the cases of thousands of individuals. Society is still a negligent stepmother who has only herself to blame if her children wander away. She ought to recognize her fault, and if, to reform the transgressor and prevent new misdeeds, she is obliged to be severe, she ought to be so with love, and with education as the only aim in view. . . . Have we, then, the right to criticize others? No; we have only one duty, and that is to pardon and stretch out our hands to those who have fallen." 1

After all these exemptions from responsibility have been made, how large is the share left to it? What murderers are there who commit their crimes neither as the result of physiological infirmities, nor under the overmastering control of some mental defect, nor as the inevitable product of social maladjustments and misery? What wrongdoer cannot prove himself to be a "born criminal" and "criminally diseased," a victim of his physical constitution, or to have been ${ }^{1}$ DuBois, op. cit., pp. 67, 74. 
rendered wayward by bad training and evil associates?

The constant efforts of criminal anthropology and sociology have steadily enlarged the field of irresponsibility. How far will this procedure of denying accountability extend? To declare crime excusable when occasioned by physiological defect, a fit of passion, or extreme misery, what is this but to recognize that whenever there is discovered a cause other than "free-will," there is no right to punish? Is it not now evident that all criminal activity is subject to laws as inflexible as those that regulate the falling of a stone? What matters it whether the influences be sociological, physiological, or psychological? A cause is none the less a cause, whether it be external or internal. After all, the distinctions here are only arbitrary. There is no force purely sociological or purely psychological. These but represent different points of view for the sake of convenience. By taking account of the facts accumulated by science, - facts concerning heredity, education, and environment, social conditions and mental infirmities, - the juridical customs founded on "responsibility" will be overthrown. "Moral" obstructions will be removed; and scientific practice and procedure may advance. ${ }^{1}$

Xerxes caused the ocean to be lashed because it would not do his bidding. We in our day laugh at his simplicity. But we condemn the criminal to be beaten because he does not obey our commands. Future generations may laugh at our folly. We are aware that the movements of the sea are governed

${ }^{2}$ Cf. Bayet, op. cit., pp. 149, 150. 
by fixed principles. Coming generations will know that the acts of the criminal are under the sway of determinate laws. Is the "brain storm" any less subject to law than the tempest on the ocean?"

${ }^{2} C_{f}$. ibid., p. 178. 


\section{CHAPTER XX}

\section{CONTRAST OF MORAL CONSIDERATIONS}

\section{AND SOCIAL EXPEDIENCY}

How can liability coexist with the general law of cause and effect. It is commonly held that belief in accountability is inconsistent with the notion that the human will is determined by causes. Seth maintained that determinism and responsibility are incompatible, and used this as a "moral argument" against acceptance of determinism. "To reduce crime to a pathological phenomenon, is to sap the very foundations of our moral judgments; merit as well as demerit, reward as well as punishment, are thereby undermined. Such a view may be scientific; it is not ethical, for it refuses to recognize the commonest moral distinctions." ' Leslie Stephen well summed up this position as follows: "Moral responsibility, it is said, implies freedom. A man is only responsible for that which he causes. Now the causa causae is also the causa causati. If I am caused as well as cause, the cause of me is the cause of my conduct; I am only a passive link in the chain which transmits the force. Thus, as each individual is the product of something external to himself, his responsibility is really shifted to that something. The universe or the first cause is alone responsible, and since it is responsible to itself alone, responsibility

$$
{ }^{1} \text { Seth, op. cit., p. } 315 .
$$


becomes a mere illusion." 1 According to Martineau, "either free-will is a fact, or moral judgment a delusion"; if determinism were true, human beings would be no more proper subjects of responsibility than are inanimate things; and "the application of praise and blame" would be "in itself as absurd as to applaud the sunrise or be angry at the rain." "To reduce the moral sentiments to a policy providing for the future, instead of a sentence pronounced upon the past, is simply to renounce them; and amounts to a confession that they cannot coexist with a theory of necessary causation." 2 "Owen and his followers from a recognition of the fact that volitions are effects of causes, have been led to deny human responsibility. ... What they denied was the rightfulness of inflicting punishment. A man's actions, they said, are the result of his character, and he is not the author of his own character. It is made for him, not by him. There is no justice in punishing him for what he cannot help." 3

These citations illustrate the generally prevalent recognition that the admission of determinism deals a death-blow to the theory of moral accountability founded on freedom of the will. Now we may as well admit that this is the conclusion to which our reasoning leads us. The facts of determinism are so plain as to be absolutely convincing, and to force us to accept all the implications. If the notion of "moral responsibility" is incompatible with determinism, as it really seems to be, we are prepared to throw

${ }^{1}$ Leslie Stephen, "Science of Ethics," p. 273.

${ }^{2}$ Martineau, "Types of Ethical Theory," 3d edition, vol. II, pp. $41,42$.

${ }^{3}$ Mill, op. cit., p. 586. Cf. "Utilitarianism," p. 128. 
away that conception. We are certainly not inclined to follow the example of those moral enthusiasts who, though every fact in the universe testified to the correctness of determinism, would nevertheless postulate "freedom" for the sake of saving "responsibility." We prefer to relinquish it, in the belief that truth cannot possibly bring more harm to man than error.

We are what we cannot but be, under the determining conditions. We are the inevitable resultant of the various forces in operation. Consequently, no one can reasonably be reproached for being what he is, for he could not be different. No one can be blamed for defective morality any more than for having been born idiotic, blind, hunchback, or club-footed. Qualities of character, instead of depending on the individual, really form the individual. Whether a man shall be Apollo or Thersytes, savant or clown, saint or sinner, does not depend upon his free personal choice. A criminal is no more morally responsible for his immorality than he is for birth-marks or natal deformities. Universal determinism being the scientific truth, moral responsibility does not exist. A being that is invincibly obliged to be what it is cannot be held responsible for not being different. A bowlder that crashes down a mountain-side, carrying destruction with it, is not held morally accountable. A tiger that attacks and kills a man is not said to be morally blameworthy. A man is as much an automaton as a rock or a tiger; and cannot justly be esteemed free to act otherwise, than he does."

The old ideas of "freedom," "responsibility," and

${ }^{1}$ Cf. Hamon, op. cit., pp. 229, 230. 
"punishment" must be given up. It now scarcely admits of question that every criminal act is an effect of causes either in the constitution of the individual or in the organization of society which make the crime necessary and inevitable. Since every wrongful deed proceeds from a person who is, temporarily or permanently, in a more or less abnormal condition, "punishment" is without justification. A monstrosity should not be "punished" for acting according to its monstrous nature. The old conception of legal penalties was founded on belief in the normality of the criminal: he was a normal person who had chosen to act abnormally - a fruit-tree, as it were, that had decided to bear thistles - and it was the business of the penologist to apportion the exact amount of retribution due for this free, though extraordinary behavior. Little or no regard was paid to the varying natures of evil-doers; they were regarded as constant factors. Punishment was directed at the offences; it did not consider the offenders at all. On the whole, it has seemed better - at once sounder theoretically and more convenient practically - to discard this antiquated notion of punishment. Many scientific thinkers and investigators are showing a disinclination to talk of "punishment," and are preferring to speak of "the social reaction against crime." Whenever an antisocial deed occurs, there is an inevitable social reaction against the person who committed it. Society gives him to understand that there must not be a repetition of the harm. To accomplish this, it acts according to its wisdom. Social reaction in a crude form lynches the crimina!; in a highly developed stage, it bestows 
elaborate training and education upon him, as at the Elmira Reformatory. The reaction against crime is a solid and permanent fact in the nature of man and society; and is independent of all metaphysical theories. It is this which should direct a scientific treatment of the criminal. ${ }^{1}$

The questions of "moral freedom," "moral responsibility," and "moral punishment" are not of the slightest consequence to social well-being. If a man "freely" wills to be antisocial, it is the right and the duty of society to defend itself from him. On the other hand, if he "necessarily" wills to be antisocial, then it is equally the prerogative and the obligation of society to protect itself against him. Society has a just privilege and a bounden duty to preserve itself in all cases. All men, whether free or not, are answerable to it for their deeds. Social accountability is the only accountability with which society is rightly concerned. The questions of moral responsibility and moral freedom are of no social consequence. Society is interested in what kind of actions, social or antisocial, the individual actually wills and performs, but not at all in whether he could have willed differently. Punishment founded on moral responsibility must be replaced by punishment based on the dangerousness of the criminal to society. The people who think that on account of the non-existence of freedom of choice, and on account of the inevitableness of all the acts of a man, no criminal ought to be punished, start from a wrong conception of punishment.

Social accountability must not be confused with ${ }^{2}$ Cf. Ellis, "The Criminal," pp. 295, 296. 
the notion of moral blameworthiness. The only task of human justice is to prove the dangerousness of the individual to society. The burden of religious responsibility should be left to the individual conscience; that of transcendental responsibility, to metaphysics. Justice dictates the duty of doing everything it can to oppose antisocial acts, to prevent their occurrence, if possible, and, at any rate, to hinder their repetition, and to repair the harm that has been done. ${ }^{1}$

With the social aspects of punishment most people mix up moral and religious considerations which presuppose the "liberty" of the criminal. In judging antisocial acts, the effort is too often made to estimate more or less exactly the part played by liberty, in the belief that a will freely bad is the only possible justification of punishment. But whether we accuse the antisocial individuals of being morally bad or not, the natural relations of things render necessary the employment of force against them, and oblige us to defend the interests of all against the violence of some. We may go back beyond the particular offender and locate the moral blame elsewhere. Nevertheless, regardless of metaphysical speculations, the determinists may justify punishment of damage-doers on the grounds of human utility, or social vindication. And this purely human and social justice does not need to depend on "the absolute." It finds a sufficient basis in social facts as they are in themselves.

${ }^{1} C f$. DuBois, op. cit., p. 73. 


\section{CHAPTER XXI}

\section{ASSERTION OF THE CRIMINAL'S SOCIAL RESPONSIBILITY}

IF we admit that criminality is the inevitable result of necessary causes, and that the criminal is not "morally accountable" for his deeds, does this mean that all repressive measures are to be abandoned by society, that assassins and thieves are to be left at large, and that prisons are to be thrown open? No. Repression of crime is as "necessary" as crime. The acceptance of the doctrine of the malefactor's irresponsibility means simply that the character of punishment is to be modified. Punishment is to be solely and exclusively a means of social protection and of amelioration. To announce that wrong-doing is an effect under recognizable laws is not to declare that the wrongdoer is to be placed in a kind of palace or earthly paradise. The life of society's criminals should not be made sweeter, easier, and pleasanter than the life of society's laborers. The criminally "diseased" and "incurable" are to be treated as sick persons, indeed, but not with luxury and deference. ${ }^{1}$

It is wrongly believed that the simple fact of cataloguing crime among the regular phenomena of sociology involves exemption from responsibility and punishment. If it is normal that there should be

${ }^{1} C f$. Bayet, "La morale scientifique," pp. 153, 154. 
crimes, it is also natural that crimes should be punished. The words "responsibility" and "punishment" are questionable, to be sure; but it is certain that the social reaction against crime is a fact normally connected with crime. ${ }^{2}$

Acceptance of the doctrine of determinism does not mean that we must stand and look on in passive impotence as harmful deeds take place. There is a social responsibility which authorizes society to repress crime, or, better, to prevent it. The solidarity of human interests requires society to do what it can for the security of the social order. A vicious animal is not thought to possess "freedom of will," but is nevertheless "punished"; and if extremely dangerous, is put to death. It is not a moral fault in a snake to possess venom. Nevertheless it is humanly and socially undesirable; and we kill a snake without pity, simply because it is dangerous to men. For wolves and lions to be carnivorous is certainly natural and proper; but it is also necessary and right for man to destroy them for his own safety. Exactly similar is the justice with which society exercises a rigorous selection and extirpation of those human individuals who violate the interests and endanger the existence of the others. The "wild beast of a man" must be restrained or eliminated."

It is said that punishment is based on responsibility, and that determinism is a flat denial thereof. A distinction must be made, however, between social and metaphysical accountability. A man does

'Cf. Durkheim, "Le suicide," p. 415.

${ }^{2}$ Cf. Royer, "Actes du deuxième congrès d'anthropologie criminelle, 1890"; quoted by Hamon, op. cit., p. 231. 
something inimical to the good of society; he knows what he does and foresees the harmful effects upon others. Punitive suffering is inflicted in order that when he thinks of repeating the deed, the idea of the consequent affliction will be a sufficient motive to restrain him. The punishment must be given to the agent. The harm was done by him. It matters not that he is the victim of bad heredity and environment and that his act was the necessary result of previous events. The tangible and corrigible source of evil is in himself. If a man is sick it is to him that the medicine is given, and not simply to the environment that caused his sickness. If the disease is contagious the man is confined, - his liberty is taken away from him. In this sense, social "responsibility" is imputed to him. The treatment is not regarded as a chastisement for moral depravity, but as a precaution dictated by considerations of social utility. Similarly, penal "medicine" may be given to the criminal; his liberty may be taken away from him. But such treatment should be considered not as punishment for moral depravity, but as rendered necessary by the demands of social well-being. For the protection of society he must be cured of his ailment, or at any rate prevented from injuring others. The punishment is administered to bring about the right order of thoughts and ideas, and to cause him to abstain from harmful action whenever the occasion arises again. If he says, "I could not help it - I deserve indulgence and pity," we reply, Of course. We do not blame you. We do not regard you as a moral reprobate. Nevertheless, this pity and knowledge of your moral irresponsibility does not keep us 
from endeavoring to prevent a recurrence of the harm. We shall try to cure you of propensities to injure others, by causing you to undergo a certain amount of suffering. The idea and fear of pain will restrain you the next time you are tempted. When the criminal performs an act contrary to the general welfare, it shows that motives of respect for the social good are not strong enough in him. Punishment is inflicted in order to strengthen these motives, and to give him additional cause to control his passion. Crime is the result of improper functioning in the criminal's mind. Even though this derangement be determined, and attributable to inheritance and bad education, the immediate cause is in the individual himself, and may be reached and remedied by the application of the proper treatment. If the desire for pleasure gets the mastery over consideration for others' property and interests, the receipt of punitive suffering will strengthen respect for others' rights, and will make evident to the criminal that the wish for plcasure if heedlessly gratified brings about pain. Thus responsibility, according to determinism, is not "moral" but is intellectual, physical, social. It denotes the capacity of being made to produce the social effects desired. Whenever this faculty exists in an individual, he is accountable. "Free" or not, man is capable of being influenced through his mind and body. The justice of penal responsibility is a question of social efficacy, and not of moral legitimacy. Social utility is the prime interest. ${ }^{1}$

Under our present practices it is frequently a matter of great moment whether a criminal is insane or ${ }^{1} \mathrm{Cf}$. Fouillée, "La liberté et le déterminisme," pp. 39-42. 
not. But whether a man is mentally deranged or not is largely a matter of definition. And even with the best definition we cannot always be certain that a given person comes within its scope. Moreover, it is difficult to see why it should make so much difference whether a damage-doer is insane or not. Why should grave interests of social and individual safety and well-being be made to hinge on a problem which must often be insoluble? It cannot make any practical difference whether a transgressor is sane or insane. Demented or not, he is dangerous, and society must protect itself from him. Lunatic or normal, society must treat him humanely, and must use all means in its power to render him capable of living a social life. The question of sanity is inmaterial, either to society or to the offender. To speak of insanity as a "defence," is both unreasonable and antisocial. Mental derangement is an explanation, but not a defence. Lunacy involves a loss of self-control, a giving way to impulse. Now, every one knows that self-control may be educated, that it may be weakened or strengthened by experience. If we accept insanity as a "defence," we are directly encouraging vice and crime, by removing the strongest influence in the formation of self-control. When a "defence" of kleptomania was brought before an English judge in a case of theft, he observed: "Yes, that is what I am sent here to cure." We need not hesitate to accept this conception of the function of the court, provided that the treatment be scientific, effectual, and humane. ${ }^{1}$

When we declare the insane person to be morally 'Cf. Ellis, op. cit., pp. 355-357. 
irresponsible for his deeds (that is to say, incapable of having refrained from committing them), we certainly do not mean to imply that he cannot be held socially accountable for them, or that his malady gives him the right to perpetrate crimes with impunity. So far as concerns moral responsibility, we are quite willing to admit that all acts are caused and could not be other than they are. And we are disposed not to stop at insanity and epilepsy, but to extend moral irresponsibility to hysteria, neurasthenia, and even headache or toothache. Nevertheless, the recognition that every event has a sufficient cause and could not have been different does not lead us to the absurd conclusion that a man is not accountable to society for his behavior. On the contrary, it induces us to affirm that every one, whether absolutely normal or profoundly insane, is answerable to his fellows for his every act. The question of mental derangement is a matter of consideration in determining the most appropriate treatment to be given by society, but does not at all affect the matter of social accountability.

Responsibility has no independent existence of its own in the mental constitution of men, so that the degree of responsibility might vary according to the degree of mentality. It is a purely social relation. It is established and maintained by men living together. If any man lived entirely apart from other men, he would have absolutely no responsibility, altogether regardless of his mental normality or abnormality. His state of consciousness would of course exist even though he were isolated from all other human beings. His conceptions and actions 
might be in perfect agreement or in total disagreement with the facts of his environment. But responsibility would not exist. On the other hand, a man living in social relations is accountable for his acts, regardless of his mental state. Accountability is a purely social affair, and applies to all men living in social relations. It is not in the least affected, removed, or attenuated by insanity, epilepsy, or other anthropological abnormality of the individual. We cannot emphasize too much this independence of the two conceptions, mentality and responsibility. Responsibility applies to all men living in society, regardless of their state of consciousness.

Society has the right to defend itself against injury. In order to do this it may rightfully make use of any means best adapted for it. It may enact laws and may attach penalties thereto, and may carry out the threatened penalties in case the laws are infracted. It does this not because man has freedom of will and is morally responsible for his acts, but because he is determined by motives and because the threat of pain for certain actions is an efficacious way of preventing these actions. The man impelled by antisocial tendencies may be restrained by fear of personal suffering. His natural inclinations would certainly be satisfied if not met and counteracted by the prospect of consequent pain. Avarice, sexual desire, brutal selfishness, cruel impulses demand satisfaction. But the legal penalties convince intelligence that the satisfaction of pernicious inclinations will entail loss of the criminal's property, liberty, or life; and they thus succeed in restraining from undesirable conduct. It is absurd to say that no penalties should be threat- 
ened against harmful actions and no punishments awarded for their occurrence, inasmuch as all acts occur of necessity and could not be otherwise. Penalties and punishments are efficient causes in the production of behavior. An individual of vicious propensities may be caused to behave properly in view of the penalties that exist for crime. Without legal threats the perverse disposition would be unable to restrain itself. "Freedom" and "moral responsibility" are not necessary to found the attempt to intimidate. And when "freedom" and "moral responsibility" are relinquished, we do not have also to abandon penalties and punishments. Even many insane and demented persons are susceptible of control through threats.

The legal penalties will deter some possible offenders from harmful deeds; but will be unable to restrain certain other criminals. Are the latter, then, socially irresponsible, because their hereditary and acquired traits drive them inevitably into crime? Not in the least. They are socially responsible, just as all men are socially responsible. No one is morally responsible for his deeds, in the sense that he is free to do or not to do them. Every one is socially responsible for his behavior, in the sense that society will deal with him in a manner which his behavior indicates to be necessary for social protection. The dishonesty of the thief and the forger, the brutality of the rapist and assassin, the insanity of the demented, are all individual, personal attributes or qualities, and make it right for society to treat such persons in the way that is best for the general social well-being; just as the honesty, benevolence, and beneficence of good 
men entitle them to the esteem and benefactions of their fellows. Moral responsibility for an act supposes an ability to have acted differently. Social responsibility makes no such supposition. It cares nothing about it. It simply adopts the social treatment of a person according to his banefulness or beneficence for the general good. Society may properly quarantine any one afflicted with a contagious disease; a fortiori, it may rightly exclude from its midst a vicious pervert. The safety of the people is the supreme law for society. Penal, corrective, and preventive treatment has a purely social foundation and justification.

The old theory of accountability was dependent upon belief in free-will. To have been responsible was thought to mean to have been able to act differently from the way one actually did act. The doctrine of free-will has now, among most thinking persons, given place to the more scientific view of determinism. Thus with the disappearance of the notion of freewill the old idea of accountability is left with nothing to rest on, and is forced to give way to a newer conception. The modern scientific doctrine is this: Every individual is socially accountable for his deeds; and social responsibility is the only responsibility with which society is rightly concerned. Society has the right and the duty of preserving itself. To do this it must hold every one, whether sane or insane, answerable for his behavior. The words "responsibility" and "punishment" are not good expressions of the present conceptions; and ought to be abandoned as soon as better terms can be found. The facts are these: Every harmful deed naturally 
provokes a social reaction; and this manifests itself in repressive, curative, and preventive treatment, in quarantine, therapeutics, and prophylaxis, applied not only to the offender, but also to the causes that produced his acts. The true nature of the social reaction against crime is well seen if instead of speaking of crime and punishment we speak of offence and defence. The case may be illustrated by society's defence against the insane. Up to about a century ago the social reaction against the demented took the absurd form of hatred, punishment, and contempt. This proved both unreasonable and ineffective; and was finally abandoned. These unfortunates are no longer held blameworthy for their character and action, or deserving of scorn and abuse. Nevertheless, they are subjected to restraint and to special treatment, for the public safety. The time has now come to do for the criminal what has been done for the insane. Madmen and criminals are both recognized as belonging to the same great and terrible family of abnormal, degenerate, antisocial persons. Both are socially answerable in the same way, and just as is every other person. Responsibility means that a man must suffer the consequences of his deeds. The reaction against antisocial behavior is a primary and inevitable fact of all social life. But it must be made reasonable, efficacious, and humane. We may ameliorate the conditions that produce injurious action; we may treat the antisocial person in such a way that he will cease to be so, and in the last resort we can place him where he will be unable to act out his mischievous impulses. We may do all this without any reference whatever 
to moral guilt or moral responsibility. The sole consideration is the good of society. ${ }^{1}$

Society has the right to defend and to conserve itself. Every one is socially responsible for the effects of his actions upon his fellows. He is responsible because he lives in a society in which his acts produce effects which react upon him in a beneficial or harmful manner according as they have been useful or injurious to society. Every act produces effects upon society and a reaction upon the actor. Every man experiences, therefore, of necessity, the natural consequences of his actions. He is thus held "accountable" in a way wholly natural, and is made to answer solely because he is the author of his deeds. Thus, naturally, "every one acts at his own risk or peril, whatever be his state of consciousness." To the diverse modes of action there correspond diverse modes of reaction. We have no need of the conceptions "freedom" and "moral responsibility," which stand for imaginary things which do not exist. It suffices that there have been acts which are in disagreement with the will and interests of society, entailing of necessity reactionary consequences upon the doer. Protective reaction is the inevitable consequence of harmful action. It manifests itself in suppressive, correctional, and preventive treatment, - a treatment addressed not simply to the inmediate cause, but also to the more remote causes, and intended as a therapeutic and hygienic measure. ${ }^{2}$

Paulsen has some passages on this subject of social accountability that are so good as to deserve citation

${ }^{1}$ Cf. Ellis, op. cit., 363-367.

${ }^{2}$ Cf. Hamon, op. cit., pp. 233-237. 
almost in full. "To refer evil to causes means to shift the responsibility upon these causes. But, it must be added, this does not alter our feelings, our judgment, and our attitude toward the worthless and evil individual. To be sure, we should say, nothing good can come from such a source; but this would not mean that the product, base though it may be, was pure and guiltless, and that we should treat it as such. Our judgment of the worth of a person depends upon what he is, not upon how he became so, and our attitude toward him depends on the same thing. ...

"As to whether society has the right to punish, or whether it is not itself the guilty and responsible party. ... We may reply to this: It is quite true; society is guilty and therefore liable to punishment, it produces individuals with criminal tendencies, it also creates temptation and opportunities for crime. But is society not punished? Is not, in the first place, the crime itself a punishment which it suffers? The person against whom the offence is committed is as much a part of society as the criminal. And the feeling of fear and insecurity caused by the crime is a further punishment. And the punishment itself, which is inflicted upon the criminal, is an additional punishment: when he suffers, a member of society suffers, the member, namely, through whom it has sinned. And finally, society as a whole suffers the punishment which it inflicts; for is it not a punishment for a nation to watch, to support, to clothe, and to employ many thousands in penitentiaries and prisons at enormous expense? Ought society to be punished in other ways? Shall all the others, with 
the sole exception of the criminal as the only innocent party, be punished? Or what do these wonderful people mean? . . .

"Some one, however, disturbed by such psychophysical speculations, might argue as follows: Well, after all, the same remarks apply to insanity. If we regard and treat this as a brain disease, why not do the same with other abnormal states? The criminal impulse of the thief or incendiary must be explained scientifically, as an inherited or acquired predisposition of the brain, and hence the person thus afflicted must be treated as diseased. Our answer would be: We can certainly look at the matter in this way; the impulse to commit arson is an abnormal tendency of the brain, likewise the impulse to steal; and of course, the impulse of the boy who wantonly destroys his playthings, or of the little girl who annoys her parents and teachers by her carelessness and fickleness, all these, too, are to be regarded as abnormal or diseased predispositions of the brain. But, now draw the conclusions. We attempt to cure diseases with the remedies which experience has found to be efficacious. If the physician can heal the insane by dietaries and shower-baths and medicines, very well; and if he can also cure those afflicted with the impulse to commit arson with the same or similar remedies, very well; we shall be glad to place such persons under his care, as well as the bad boy whose pranks annoy us. But in case his remedies prove unsuccessful here, let him not hinder us from trying other cures, especially such as have stood the test of experience; for example, for bad boys a natural remedy that grows on the hedges. And in case 
he cannot reach the impulse to steal or the impulse to destroy, by the remedies of the apothecary, let him allow us in the meantime to continue the use of an old remedy which, though not absolutely sure, has nevertheless met with a certain degree of success as an antidote against such impulses; that is, the prison and the penitentiary. So soon as he discovers a more certain, simpler, less roundabout and expensive specific, we shall be glad to dispense with these disagreeable and inadequate cures of ours.- But why do you not treat the maniac in the same way, why do you not bring him before court, and sentence him to jail when he commits a crime? - We should certainly do so if we believed that the treatment employed by judges and prison-guards would produce better results in his case than that applied to him and others similarly afflicted, by physicians and nurses. In the meanwhile, we are of the opinion that to subject him to the process of the criminal law would make no impression upon him, would have no such influence upon his future behavior as the rod has upon the boy, or the penitentiary has - at least occasionally - upon the thief and his possible successors. Besides, we certainly do place the insane person under restraint when he becomes dangerous to himself or to others, and protect ourselves against him, so far as we can, as much as against the thief.

"Indeed, it is a very strange procedure, first to explain criminal impulses as diseases, and then to conclude from this that nothing ought to be done against them. Against diseases we employ all remedies that help, even though they burn and smart." I

${ }^{2}$ Paulsen, op. cit., Bd. I, S. 454-460, tr. Thilly, pp. 461-467. 


\section{CHAPTER XXII}

\section{BASIS OF PERSONAL ACCOUNTABILITY}

Withour freedom of the will, what becomes of merit and demerit, and how shall we establish the legitimacy of punishment? Afflictive penalty may be necessary as a means of social defence, but is it just? To this query we reply by asking, What is "merit"? In brief, "merit" implies "social value," and nothing but that. It is not at all affected by the question of free-will. Thus the legitimacy or justice of punishment or reward consists in the proportion between the social value of the agent and the fortune which society assigns to him.

What, in general, is meant by responsibility? Responsibility indicates liability of punishment. When we have the feeling of being responsible for our actions, the idea of being subject to penalty for them is uppermost in our mind. Whoever has an essential disposition to wrong-doing becomes a natural object of the active dislike of his fellows, if they discover it. He not only forfeits the benefit of their good-will and beneficence, except when their compassion is stronger than their dislike for him; but he also renders himself liable to whatever they may think necessary to do in order to protect themselves against him; which will probably include actual punishment, and will surely involve much that is equivalent. In this way, he is certain to be made accountable to his 
fellow men, through the normal action of their natural sentiments. This practical expectation of being made to answer for actions has a great deal to do with the internal feeling of being accountable; a feeling which is seldom found existing in any strength in the absence of that practical expectation. Oriental despots, who cannot be called to account by anybody, have little consciousness of being morally responsible. In societies in which caste or class distinctions are rcally strong, it is a matter of daily experience that persons may show the greatest sense of moral obligation as regards their equals, who can make them accountable, and not the least trace of a similar feeling toward their inferiors who cannot. ${ }^{1}$

Every day the ordinary individual recognizes merit and demerit. What criterion does he use in distinguishing what deserves praise or blame from what does not? What common mark attaches to all those actions for which the untutored moral consciousness holds the doer accountable? The natural mind holds a man responsible for what he himself did; it relieves him of responsibility for what he was compelled by some superior power to do. If a desperado places a pistol at my head and forces me to sign my name to a pernicious libel, I am not held to account for the libel, because it was strictly not mine, but that of the villain who threatened me. What I did was to sacrifice a certain duty for the sake of saving my life. For that alone I am responsible. This principle of responsibility is the same in all other cases, though in the questions of real life it may become infinitely complicated. The fundamental principle, however, is ${ }^{1}$ Cf. Mill, op. cit., pp. 586-588. 
always this: A man is responsible for what he himself does. This stakes the case of responsibility for an act upon a simple and intelligible inquiry, Was this man really the doer of the act in question? ${ }^{1}$

A harmful act, then, for which the culprit is socially amenable; is one that is expressive of the self of the agent. A person is held liable only if his action is regarded as caused by his own will or nature. If his arm or his foot gives a push to us, and we are convinced that the push was neither intended nor forcseen nor due to any carelessness on his part, we cannot feel angry with him. We make a distinction between a part of his body and himself as a volitional being, and think that he is not a proper object of resentment when the cause of the hurt was merely his arm or his foot. An event is attributed to him as its cause only in proportion as it is regarded as having been brought about by his will; and he is considered a proper object of resentment only as an intentional cause of pain. We do not resent hurts received from animals, little children, or madmen, when we recognize their inability to judge of the nature of their acts. They are not the real causes of the resulting mischief, since they neither intended nor could have foreseen it. We cease to be angry if we discover that he who injured us acted under compulsion, or under the influence of a non-volitional impulse, too strong for any ordinary man to resist. Then, the main cause of the hurt was not his will, conceived as freely acting. It yielded to the will of some one else out of necessity, or to a powerful impulse which forms no part of his

${ }^{2} C f$. Scott, in International Journal of Ethics, April, 1910, pp. 332,333 . 
real self. He was but an instrument in another's hand, or he was "beside himself." Full responsibility presupposes freedom from non-volitional pressure, and, particularly, freedom from external compulsion. When a person's will is compelled by a power outside him, he cannot be held to account for what he does under the influence of that constraint. $\mathrm{He}$ is answerable only for what is due to his will. ${ }^{1}$

By degrees punishment is coming to be recognized as simply a measure of social precaution. But this precaution must consider, besides the act and its motives, the underlying will. From the fact that a judge never has to ask himself whether a crime is morally or metaphysically free, it does not follow that he may ever neglect to examine with what amount of attention and intention, or with what degree of conscious will, it has been accomplished. This will, whatever its ultimate metaphysical nature may be, is mechanically a force whose intensity should enter into social calculations. It is simply the character, - the system of tendencies of every sort which the individual customarily obeys and which constitute his moral self, - or the resistance which the individual's reserve of interior energy is capable of presenting to antisocial inducements. The consideration of the punishing authorities will always bear, not solely upon the discovery of what influences determined the given deed, but also upon the character of the accused. Their judgment will regard, not simply motives and impulses, but the person (who is only a complicated system of motives and impulses counteracting each other and forming a more or less stable

${ }^{\prime} C f$. Westermarck, op. cit., vol. I, pp. 315-324. 
tendency to action). Even though there exists no moral responsibility, but purely a social responsibility, the individual is answerable, not only for the particular antisocial act and the motives that led him to it, but also for his nature. And it is this that punishment should seek to improve. Juries always judge the person, letting themselves be influenced by good or bad antecedents; and in principle they are not wrong. An act is never isolated, but is a symptom. The social sanction should bear upon the entire individual.:

With reference to social responsibility a distinction must be made between acts caused by intellectual necessity and those produced by physical constraint. We are responsible for the first, but not for the second. If any one is compelled by external force to do a criminal deed, he cannot be punished without feeling the treatment unjust. But if the influence that determines him is in his brain, an internal necessity of desires, interests, motives, then punishment for the crime will be recognized as just. A man does not shift the responsibility for his misdeeds from himself to the motives in consequence of which the deed necessarily took place. For he knows very well that this necessity has a subjective condition, and that so far as the objective conditions are concerned, under the same circumstances and under the influence of the same motives an entirely different act, even the very contrary of his own, could have taken place, if he had been different. Here lies the whole blame. It was because he had such and such a character, that

${ }^{1} C f$.'Guyau, "Esquisse d'une morale sans obligation ni sanction," pp. 214, 215. 
no other action was possible. The circumstances did not produce the action of themselves. Motives and acts are merely an index or expression of the fundamental nature, the unalterable direction of the will, the "character." Responsibility for a deed, therefore, must be borne by the man himself.

There are persons who declare that on the basis of determinism, the rightfulness of inflicting penal suffering must be denied. They say: "A man's actions are the result of his character, and he is not the author of his own character. It is made for him, not by him. There is no justice in punishing him for what he cannot help." Now is it really unjust for determinists to punish a criminal for actions which were inevitably necessary? The decision of the question rests on the nature of the causes which made it impossible for him to behave otherwise. If they were foreign to his own nature, if they were independent of his own will, if they were some form of external physical constraint, then truly it would be unjust to make him answer for the deed. The laws of practically no country subject a man to penalty for what he was compelled to do by immediate danger of death. But if the causes of his action were internal and inherent in his own nature, if they depended upon his own will or character, if they led to a deed expressive of himself, then it is perfectly just to punish him for "what he could not help." No malefactor will feel that because his wrong-doing was the result of definite motives, operating upon a certain mental disposition, it was not his own fault. It was at all events his own defect or infirmity, for which punishment is the appropriate cure. The particular kind of 
defect or infirmity which he has displayed, - insufficient love of good and aversion to evil, - is in every one's mind the standard of fault.

Thus, to the free-willist's argument that because the criminal cannot refrain from his wrongful deed it cannot be just to subject him to penalty for doing it, the determinist replies that the expectation of being punished for committing a crime does enable most persons to keep from it, and is precisely the best means by which to give them this ability. To say of a certain man that he cannot help committing a crime, is true or false, according to the qualification attached to the assertion. Supposing the man to be of a vicious disposition, he cannot abstain from misconduct, if he is allowed to believe that he will not be called to account for it. But if, on the contrary, he is made to know that he will be severely punished, he can, and in most cases does, help it. So the question, "How can punishment be justified if man's actions are determined by motives?" is not very perplexing when we bear in mind that the punishment itself is intended to become one of the determining influences. The really puzzling and unanswerable question is, "How can punishment be justified if man's actions are not determined by motives?" If punitive treatment could not act on the will and influence future conduct, it would be illegitimate, no matter how natural the inclination to inflict it. In so far as the will is regarded as free, that is, as capable of acting against incentives, penalty is inefficacious in governing the will and is unjustifiable. If the man's will and behavior are supposed to be beyond the reach of inducements, there remains no reason 
for inflicting pain upon him, since that pain, by supposition, cannot possibly operate as a deterring motive. $^{1}$

Social accountability, then, is perfectly compatible with determinism, - indeed, even with the most exaggerated form of fatalism. "Suppose that there were two peculiar breeds of human beings, - one of them so constituted from the beginning, that however educated or treated, nothing could prevent them from always feeling and acting so as to be a blessing to all whom they approached; another, of such original perversity of nature that neither education nor punishment could inspire them with a feeling of duty, or prevent them from being active in evil doing. Neither of these races of human beings would have free-will; yet the former would be honored as demigods, while the latter would be regarded and treated as noxious beasts: not punished perhaps, since punishment would have no effect on them, and it might be thought wrong to indulge the mere instinct of vengeance; but kept carefully at a distance, and killed like other dangerous creatures when there was no other convenient way of being rid of them. We thus see that even under the utmost possible exaggeration of the doctrine of Necessity, the distinction between moral good and evil in conduct would not only subsist, but would stand out in a more marked manner than now. . . . A human being who loves, disinterestedly and consistently, his fellow creatures and whatever tends to their good, who hates with a vigorous hatred what causes them evil, and whose actions correspond in character with these feel${ }^{1}$ Cf. Mill, op. cit., pp. 591, 592, 599, 600. 
ings, is naturally, necessarily, and reasonably an object to be loved, admired, sympathized with, and in all ways cherished and encouraged by mankind; while a person who has none of these qualities, or so little that his actions continually jar and conflict with the good of others, and that for purposes of his own he is ready to inflict on them a great amount of evil, is a natural and legitimate object of their fixed aversion, and of conduct conformable thereto: and this whether the will be free or not, and even independently of any theory of the difference between right and wrong. . . . What I maintain is, that this is a sufficient distinction between moral good and evil: sufficient for the ends of society and sufficient for the individual conscience; that we need no other distinction; that if there be any other distinction, we can dispense with it; and that, supposing acts in themselves good or evil to be as unconditionally determined from the beginning of things as if they were phenomena of dead matter, still, if the determination from the beginning of things has been that they . shall take place through my love of good and hatred of evil, I am a proper object of esteem and affection, and if that they shall take place through my love of self and indifference to good, I am a fit object of aversion which may rise to abhorrence." 1

We say that a man who commits a crime under hypnotic influence is not responsible for his act. Now if the hypnotized person is not accountable for his deeds, how can we hold an ordinary person liable? The latter's acts are all caused by suggestions received from parents, teachers, associates, 
books and newspapers. In short, he is caused to perform his acts as truly as the hypnotized person. How can we consider the one responsible, the other not? What is the difference? There is a fundamental distinction. The behavior of the hypnotized person does not represent his character, his will, himself. The suggestions received produce action immediately, without being incorporated by the character. But the suggestions received by the ordinary person do not produce action inmediately; they go through a long process of naturalization; they must be assimilated by the ideas, habits, associations, desires, purposes, which are already present in the character. They have to become an integral part of the disposition; and then can exervise only their proportionate influence in deter nining colvruct. The act of such a person is not caused by one incitement;, but by the total previous ch acter plus this one impulse. This particular influen: : therefore, is but a very small part of the force th $t$ actually accomplishes the result. It has no power yntil it has become identified with the self. The difference between the behavior of a hypnotized person and one not hypnotized is fundamental. The performances of the first are not at all expressive of the character of the agent; the conduct of the second is wholly so.

In trying to decide on a criminal's responsibility for an act, the point of consideration is not whether he did it of necessity, that is, whether he was necessarily determined to its performance, and could not have helped it. Of course that was the case, just as it is the case with any of us in anything we do. Law, regularity, determinism obtain everywhere. In try- 
ing to estimate accountability for a crime, we must ascertain whether the deed was due to the character of the criminal, that is, to causes internal in his nature, or whether it was due to some external causes. In order that it may be imputed to him, it must belong to his own personality, to his own inner self.

One is not accountable unless he is really the agent. He can have no merit or demerit except for that which he himself did. To be responsible means to be able to say, These are my acts; I accept them as mine; after having willed to do them, I will still to have done them; I recognize myself in them. All that there is in them which is not myself, I reject, and I repudiate the responsibility therefor; I refer the merit or demerit therefor to others. Edch of 3 y actions I have myself done; without nfy will, it could not have taken place

The foundation of social accountability is the personai activity of the agent. We can distinguish behavior (whether "free" or not, is not the question) which conforms to the innate charg uter of the person, from that which does not correspend with his inner nature. In the first case, the individual is answerable for the behavior, because it is intrinsically his own. In the second case, he is not responsible. Now, the criminal's perversity belongs exclusively to him; it is his distinctive peculiarity. The dishonesty of the thief or the violent disposition of the murderer is his inherent personal characteristic just as truly as honesty is an intrinsic possession of the honest man. Every man is responsible for his natural traits. But if some extraneous quality is in-

${ }^{1}$ Cf. Guyau, "La morale anglaise contemporaine," pp. 353, 354. 
serted into one's life, a parasite upon the original character, and leads to an action that is not conformable with the real nature of the agent, he is not responsible for it.

The essential and sufficient condition of accountability is that the act emanates from the person himself, a caused cause, yet nevertheless a cause. Thus responsibility is based on the idea of personal authorship, and not on the idea of freedom of the will. The latter notion is so obscure and so variously understood by different people that it is incapable of service in penology. No one is certain where freedom begins and where determinism leaves off: But nearly all men perceive accurately enough the distinction between "me" and "not me," between "mine" and "not mine." Most men know very well the boundaries of the aomain of self; and whether an act is due to self or has an extraneous origin. This knowledge of the personal self is a sufficient ground for amenability for actions. The difference between external constraint and internal causation is obscured in the doctrine of freedom of the will as the foundation of accountability. But when we accept the personal activity of the agent as the basis, the distinction in responsibility between acts due to outer compulsion and those due to inner causation is readily recognized. I know that when I am forced by something external to do an act it is not I who do it. On the other hand, I know that when I accomplish something because it is in line with my desires, habits, appetites, ideas, it is I who do it. For the first I am not answerable; for the second, I am. 


\section{CHAPTER XXIII}

\section{THE BASIS OF SOCIAL CONSTRAINT}

THE preceding chapter probably made clear the basis of personal responsibility, and furnished us with a criterion as to when and why an individual may rightly be apprehended and punished for harmful deeds. The present chapter will maintain that the final justification of penal treatment, as such, is social utility. The reason for holding a man socially responsible for injuries inflicted by him is not that he could have refrained and ought to have refrained from them. We know that every act of his was inevitably necessitated and could not have been different. The real ground for social constraint is simply that of sociai utility. Any being whatsoever whose acts are injurious to society is made to answer for them, and is dealt with in whatever way promises to be most appropriate for the protection of society in the future. Such treatment is not strictly "punishment," but is simply social therapeutics and hygiene. It needs no other justification than this. Most assuredly, the legal treatment of crime cannot be justified on the basis of "moral responsibility on account of freedom of the will"; for such freedom and responsibility do not exist. It can be justified, and is justified, solely on grounds of social utility. In punishing a criminal, society is taking precautions in self-defence. Whether a damage-doer is endowed 
with free-will or not, it is just for him to be punished so far as is necessary for social protection, as it is just for a wild beast to be put to death (without unnecessary suffering) for the same purpose.

If any one thinks that punitive suffering is not sufficiently vindicated by being administered for the protection of society, how can he reconcile his sense of equity to the punishment of those fanatics who murder kings and rulers in obedience to a perverted conscience? Such do not regard themselves as criminals, but as heroic martyrs. If they are justly put to death or otherwise punished, the justice of the treatment has nothing to do with the state of mind of the offender, further than as this may affect the efficacy of the treatment. It is impossible to assert the rightness of inflicting penalty for the crimes of fanatics on any other ground than its necessity for the protection of society. If that is not a sufficient reason, there is none. All other imaginary justifications break down in the case of these persons. Their outrage of the obligation to respect life is an act of self-sacrifice to what they consider a higher and more sacred duty. But they are punished, - punished for what they regard as acts of sublime virtue. The motive for their abominable deeds may be a supposed duty to God, which they deem to be absolutely imperative. Will any one persist in thinking that such people are "punished" for "moral guilt," on account of their "moral responsibility"? The only real justification of society's infliction of suffering on any one is that of social necessity, social expediency. ${ }^{1}$

The right ground of punitive action, then, is the ${ }^{1}$ Cf. Mill, op. cit., pp. 596, 597. 
consideration of social well-being. This furnishes the only just reason why any person should be punished by society. Justice is simply and only a particular kind of social utility. "That Justice is useful to society, and consequently that part of its merit, at least, must arise from that consideration, it would be a superfluous undertaking to prove. That public utility is the sole origin of justice, and that reflections on the beneficial consequences of this virtue are the sole foundation of its merit; this proposition, being more curious and important, will better deserve our examination and enquiry. . . When any man, even in political society, renders himself by his crimes, obnoxious to the public, he is punished by the laws in his goods and person; that is, the ordinary rules of justice are, with regard to him, suspended for a moment, and it becomes equitable to inflict on him, for the benefit of society, what otherwise he could not suffer without wrong or injury. The rage and violence of public war; what is it but a suspension of justice among the warring parties, who perceive, that this virtue is now no longer of any use or advantage to them? The laws of war, which then succeed to those of equity and justice, are rules calculated for the advantage and utility of that particular state, in which men are now placed. And were a civilized nation engaged with barbarians, who observed no rules even of war, the former must also suspend their observance of them, where they no longer serve to any purpose. ... Thus, the rules of equity or justice depend entirely on the particular state and condition in which men are placed, and owe their origin and existence to that utility, which results to the 
public from their strict and regular observance. Reverse, in any considerable circumstance, the condition of men: Produce extreme abundance or extreme necessity: Implant in the human breast perfect moderation and humanity, or perfect rapaciousness and malice: By rendering justice totally useless, you thereby totally destroy its essence, and suspend its obligation upon mankind." 1

We have hitherto restricted our use of the word punishment to the penalties of the law. But of course the legal penalties are not the only ways in which society punishes an offender. Public opinion, blame, scorn, cuts, snubs, jeers, taunts, hisses, caricatures, boycott, withdrawal of coöperation and patronage, and many other ways are constantly made use of, and are about as effective in restraining from social harm as are the more definite measures of the law. These and all similar forms of chastisement are justified only by the principle of social utility. With this as its justification, punishment may be regarded as the "protector, not alone of the labors of living men for themselves, but also of the labors of bygone men for coming generations, guardian not merely of the dearest possessions of innumerable persons, but likewise of the spiritual property of the human race - of the inventions and discoveries, the arts and the sciences, the secrets of healing; and the works of delight." 2

This view regards an act as criminal and deserving

${ }^{1}$ Hume, "An Enquiry Concerning the Principles of Morals," sect. III, "Of Justice," part I. Cf. Mill, "Utilitarianism," chap. on "Justice"; Bentham, "An Introduction to the Principles of Morals and Legislation," chap. II, sect. 19.

${ }^{2} C f$. Ross. op. cit., p. 442. 
of penalty because it is contrary to the social interest. In the ultimate analysis, punishment must be regarded as justified by its being an expression of the general social will. Society expresses its disapproval of acts by corrective penalties. It disapproves because the acts are regarded as prejudicial to the attainment of the social will. Punishment is justified, not because it is right, but because it is good. It is good, because it satisfies the social will. What is the social will? The will of the individuals having the power. Might makes social right. This statement seems in flagrant opposition to the basal utilitarian tenet that in the good of society each individual is to count for one and only one. This latter principle may seem to many to be a "moral" principle, resting on a priori grounds of right. But in reality, it has its foundation in the actual nature of men and society. The actual nature of men is such as to make, speaking in general terms, each individual count for one and only one. Taken in the large and in the long run, the power is with the many. It is the will of the many that determines social right; and the determination of this right rests on the might of the many to make their will prevail. So it is correct to say that ultimately might makes right. This is in accordance with the movement of evolution and its laws. Punishment is but an aspect of the struggle for existence. Society's right to punish is based upon the necessity of punishment from the view-point of social utility, a necessity imposed by the struggle for existence.

An act is a crime in so far as it contravenes the will of society. It does this in so far as it injures or works 
against the good of society. Society's good determines its will; its will determines the obligatory. The right to punish is wholly a social right. It cannot be based on anything external to society, because no obligation can be proved to exist on the part of society toward anything else. For socicty, its own will is supreme. It punishes what is contrary to its will. Its right to do this is grounded in the fact that there is nothing higher than its will to make it not right that its will should be law and the foundation of obligation.

Why "ought" society to punish? Why "ought" it to do anything at all? Simply and solely because it "wills" to do it. Its will is the ultimate source of all social authority. If the socially right is not determined by the will of society, by what is it determined? If society's authority does not proceed from its own will, whence does it proceed? It certainly cannot emanate from anything external. For society, there is nothing superior to itself. It can derive from no outside source a privilege that is superior to the right grounded in its own will. Its laws need nothing else than its own will to make them valid. Its will is the ultimate basis of all dependence.

The author's book on "The Duty of Altruism" establishes the truth of the proposition that there can be rationally set up over the individual no external authority of moral obligation superior to the individual's own will; in other words, that man's moral riches must be regarded as the spontaneous creation of his own nature, which is intrinsically goodgoodness is man's natural and normal possession. 
Precisely similar lines of argument could establish the truth of the proposition that there can be rationally set up over society no external authority or moral obligation superior to society's own will. No "duty" can be imposed upon society; for that "duty" would have to be founded on some "good" greater than the good of society. But for society no good can surpass its own. Its good is determined by its nature, by what satisfies its will. Its own will is its highest law.

There is nothing outside of society that can give to it the right or power of commanding, and can beget in the persons commanded the duty of obedience. Society bases its authority to command in its own will or nature. It does not pass a decree ordering its members to keep its statutes. This would be absurd. If they were not before bound to observe its ordinances, then they could not be obliged to heed this one. The truth is, that de facto they are required to obey its laws or else suffer the consequences of their disobedience. The obligation to obey its laws is older than all laws, and rests not in some external authority or arbitrary enactment but in the nature of society. What obligates the members of society is the fundamental and unchangeable will or nature of society.

What is "the social will"? Is it to be deemed some mysterious entity separate and different from the individual wills? Is it to be regarded as the will of the majority of the people who compose society? In the last analysis, the social will reduces simply to the will of those persons who have the power.

Why call it the social will? The consideration that 
"society" is, after all, nothing but the totality of the individuals who constitute it, might at first seem incompatible with the position that the right of punishment rests on the social will. The expressions "society" and "social will" are used to indicate the fact that the separate individuals are organized and that their wills agree in such measure as to take shape in something specific, determinate, and unitary. To speak of "the social will," even though it is not a distinct entity, is no more improper than to speak of the individual will. For, as a matter of fact, this also is not a distinct entity. It is rather an organization of component elements (impulses, cravings, appetites, wants, passions, desires, wishes, etc.). Nevertheless, the organization is so complete that acts have a unity and determinateness which make it strictly proper to speak of the person's will. Similarly, the component wills of society are so organized as to give forth determinate, specific, and unitary expressions; and so it is perfectly legitimate to regard these as expressions of "the social will."

One might be tempted to consider it a valid objection to say: "If the socially right and obligatory are wholly dependent on the will of society, they are subject to caprice. They are not right and obligatory naturally, or in and of themselves, but only arbitrarily, that is, because willed to be such by society. Society might later will each to be changed into its opposite." Such an objection is founded on the failure to discriminate between the principle of right and some specific application of the right. The principle is not subject to change; but specific applications vary as the needs of society alter according to time 
and circumstance. What is socially necessary at one age may not be required at another. But the principle of obligation remains the same - the will of society. This is not something capricious. It is the same as the fundamental nature of society; and to say that the right and obligatory rest on society's will is to say that they rest on its fundamental nature. Now, this is not fitful or unstable. It is what it is, and could not be different, and could not will to be different. It could not will to be different unless it were already different from what it is - a contradiction in terms. Hence, when the right and obligatory are founded on the nature or will of society, they are given a perfectly stable and secure foundation. They are not declared variable and uncertain; for their basis, the nature of society, is not changeful and capricious.

If it be further objected that the will of society is shown to be subject to change and caprice by the fact that the civil powers sometimes command a thing to be done which was not before obligatory, and sometimes order a thing not to be done which was before demanded, it may be replied that these enactments of law must not be identified with the fundamental will or nature of society. Sometimes what is required by the law may really not be right. On what ground can it be declared to be not right? Only on the basis of the real nature of society's will. The act in question is not truly an expression of society's will. Thus, the proof that some legal decree is not binding is drawn not from something outside of society but from another and deeper reading of the essential nature of society.

It might be thought that the will of society is not 
to be regarded as the determiner of right and wrong, justice and injustice, but only of what must be done if punishment is to be avoided; in other words, that it commands, and backs up its commandment with a threat of penalty, but does not morally obligate. The difficulty here is due to confusing the will of society with the decrees of the law. Society delegates the function of framing laws to certain of its members; and sometimes the laws which these members make are not in accord with the real will of society. There may be a conflict between what is demanded by the legal statute and what is required by the nature of society. The individual of great insight may see that the law-makers have misinterpreted the needs of society and have passed a decree which is at variance with those needs. He may feel justified in refusing obedience. But in any such case, the appeal to a superior source of right is not to something other than society, but to the deeper nature of society which is expressed in law. The way in which the law is proved to be not obligatory is by appealing to a higher court of society than the lawcourt that enacted it. But the appeal is still to society and its will. Wherefore, it appears that what makes any act a duty is not its enactment as a law but its agreement with the nature and will of society. Legal ordinances do not create any new obligations, but merely attempt to give determinate expression to the will of society, which latter is the foundation of all social obligation. A legal statute obligates by virtue of being in accord with the nature and will of society, and it obligates no more than the degree of this accord. 
Neither must we be misled when the distinction is made between acts that are commanded because they are good and just, and acts that are good and just because they are commanded. The confusion is between the fundamental will of society and the provisional or experimental will as expressed in law. With this discrimination in mind, both statements may be true. The law requires acts because they are good and just; and acts are good and just because required by the real nature of society. Nothing is socially good or evil, right or wrong, just or unjust, deserving of reward or punishment, except as grounded in the nature or will of society. The right is wholly defined by the good; the good is purely human well-being. 


\section{CHAPTER XXIV}

\section{PRACTICAL PROCEDURES. CONCLUSION}

THE conclusion to be drawn from the acceptance of determinism is that the determining causes of crime should be sought and found and removed, or at least attenuated as much as possible. Combat alcoholism, remove the causes of poverty and misery, educate the children. Practice the thousand and one means of social hygiene and prophylaxis. There should be not only measures of prevention, but also measures of repression and cure. The public must be guaranteed against the attacks of criminals. Dangerous individuals must not be left at large to menace life and property. After society is protected, it is also to the common interest to look after the lot of the criminals themselves. Punishment is to be administered not as an end in itself, but as a medicine, a therapeutic treatment, appropriate for the particular individual, and calculated to better his condition and to render him inoffensive, to cure him of his malady and to restore him to society as constructive instead of destructive.

The deterministic conception regards people as being only what they must be by virtue of inheritance and experience, as deserving of pardon for their faults, and as worthy of a love which will try to lead them into better living. It takes people as they are, and admits that they could not be different. On this 
account, it feels an indulgence and sympathy which forgives the past, and looks forward with hope to the future.

The determinist thinks that crime and criminals are natural phenomena that should be studied with scientific care and by precise methods, in order to discover and apply the appropriate measure for protection. For this end he makes use of scientific anthropology, psychology, and sociology. The anthropological characteristics of the offender can often furnish a clear indication of his dangerousness to society and of what treatment would be best. The anthropologist can tell us whether a particular transgressor is a born, an insane, or an epileptic criminal. Psychological examination will reveal his mental anomalies, his impulsiveness, his lack of resistance to anger and passion, his vicious tendencies when under nervous excitation or alcoholism. The psychologist can inform us whether a special wrongdoer is a habitual, a passional, or an accidental criminal. Sociology will make known to us the social causes of crime, and whether the misdeed of a certain delinquent was due to defective education, to economic misfortune and poverty, to political corruption, or to bad home conditions.

The discovery of the real causes of the culprit's action will indicate the treatment adapted to his specific needs. This system founded on the individual's needs will of course be of greater social usefulness than the present method, which is based on the damage of the definite crime.

Scientific procedure, then, will be adjusted to the peculiar character of the individual criminal. In the 
application of punishment attention will be paid to modifying it according to the mental and physical condition of the patient. The error and injustice of a correctional process which results in increasing the criminality of the subject will be avoided. The reformable will be reformed; while the incorrigible and incurable will be held fast the remainder of their days. The instinctive and the insane transgressors, those persons in whom the tendency toward a life of crime is inborn, will be kept permanently confined either in prison or asylum. The epileptic will be placed in a suitable institution where he may be cared for and at the same time prevented from hurting himself or others. The delirious alcoholic will be put in a hospital for the inebriate and will receive special psychiatric treatment. The wild beast of a man will be kept in prison for life or put to death. The professional criminal, who has gone into crime as a profitable business, will be dealt with so severely as to convince him of its unprofitableness. The chance delinquent, the wrongdoer by accident, will receive an education calculated to strengthen his character and to develop motives of a kind to guarantee against future lapses. The young offender, the first offender, and the petty offender will be saved from the demoralizing effects of prison life and the mingling with vicious criminals; they will be placed on probation and left in freedom conditioned upon future good behavior. In case of repetition of their misdemeanors they will be sent to penal institutions of varing nature and severity, according to the needs, and will be committed with indeterminate sentences, "to be kept until cured," to be detained until con- 
sidered worthy of reinstatement in society. The decision concerning kind and length of treatment will be rendered, not by the sentencing judge, but by the directors of the houses of detention and correction, who watch the cases from day to day, with the right of appeal to a superior court consisting, perhaps, of the state prison commissioner, the sentencing judge, and the warden of the institution. Agencies will be established for educating backward children, for improving juveniles, and for aiding discharged prisoners.

The criminal class is so costly to society (by its damages to property and person, by its tremendous monetary tax, and by the constant terror in which all the people are forced to live), that we are apt to overestimate the number of criminals. As a matter of fact, the criminal class does not compose more than one or two per cent of the population, while the actually dangerous group is considerably smaller still. A very large proportion of imprisonments is due simply to inability of the prisoners to pay a small fine for breach of some petty ordinance like that against sleeping in a park, begging, fighting, or drunkenness. The problem, in such cases, is a problem of poverty rather than of crime. It is of course unfortunate that these poor people should violate the laws; it is a greater social misfortune that they should be so poor; it is the worst calamity of all, however, that they should go to prison. An improvement in the economic condition of the mass of the people would cut the prison problem in half. A great part of the remainder of this problem has been shown to be really one of mental disease, its treatment and cure. 
In some such ways as these which have been suggested, the phenomena of criminality and crime will be established upon a scientific basis, and efficacious measures of repression and prevention will be found. The most useful treatment will be applied to the criminal, with the aim of accomplishing the greatest good for all, including himself; and the social causes of crime will be discovered and removed.

All this procedure will be based on the belief that determinism is the correct explanation of human action and the conviction that social utility is the proper motive for social endeavor.

The doctrine of determinism does not lead to pessimism; on the contrary, it affords the only stable basis for hope and cheerfulness. It seems to us right to say that, taken in the large, men are good. In general, they have the disposition to identify the interests of self with the interests of others. Normal man shares the life of his fellows. He rejoices in their joy, and is sad in their sadness. He is intrinsically good. He has been made good by the operation of natural laws. Thanks to the working of those forces which evolutionists and social psychologists have discovered and described, the distinction between "I" and "Not I," "Mine" and "Not Mine," is being transcended. The normal, healthy human being lives too largely to live only for himself. $\mathrm{He}$ accumulates a surplus of life, a superabundance, which demands a giving away. In his essential character there are powers that press for activity in and through his fellows. He is constrained by his constitution to love others and to live in and through them. Man's entire being is social. In all directions 
his life is open to his fellows. At all points he invades their lives, and from all sides is invaded by them. Disinterestedness, goodness, generosity are inseparable from his nature; they are vital necessities of his existence. This naturalistic view regards goodness as man's natural and normal possession. Altruism must not be represented as acquired artificially - it is inherent in human nature. Man's moral riches are his spontaneous creation. ${ }^{1}$

So the doctrines of determinism and naturalism contain nothing to frighten us. Many people regard them as implying slavery to animality, passion, and lust. But man may be dominated by goodness instead of by evil. And if we have rightly observed and interpreted human nature, man is peculiarly constrained by beauty, truth, and goodness. But his is not an external bondage; he is constrained by his own constitution to love the things that are pure and lovely. His morality is the result of his superabundance. Normal man does not regard it as an unpleasant compulsion to promote the happiness of his fellows. He does not think when serving them, "I hate to do this, but I am afraid not to do it." On the contrary, he loves his fellows, rejoices in their welfare, and gives of his life to them. To explain morality, then, no external constraint is needed. The internal forces of human life itself suffice.

Our hope and our faith are in the completeness of determinism. All men are of necessity what they are, and cannot be otherwise; and they do of necessity what they do, and cannot act differently. But

${ }^{1}$ For expansion of these ideas, see the author's "Duty of Altruism," chapter on "The Will to Live the Largest Life." 
we rejoice that this determinism is a determinism of virtue and not of vice. Normal man simply cannot do evil, because he cannot act contrary to his character, which has been made for righteousness. $\mathrm{He}$ is not good in obedience to a command, but because that is his intrinsic disposition. He recognizes no imperative to serve others; but in his own nature he experiences a constraining impulse to serve them. He loves his fellow-men, and strives for their happiness. Truly, his will is not free in this; it is necessitated. He loves others because he must. $\mathrm{He}$ cannot help loving them. It is a vital demand of his nature. He cannot be other than himself. He rejoices in living out his nature, in fulfilling the life of love. 


\section{University of Californla}

SOUTHERN REGIONAL LIBRARY FACILITY

305 De Neve Drive - Parking Lot 17 - Box 951388

LOS ANGELES, CALIFORNIA 90095-1388

Return this material to the library from which it was borrowed.

B! 

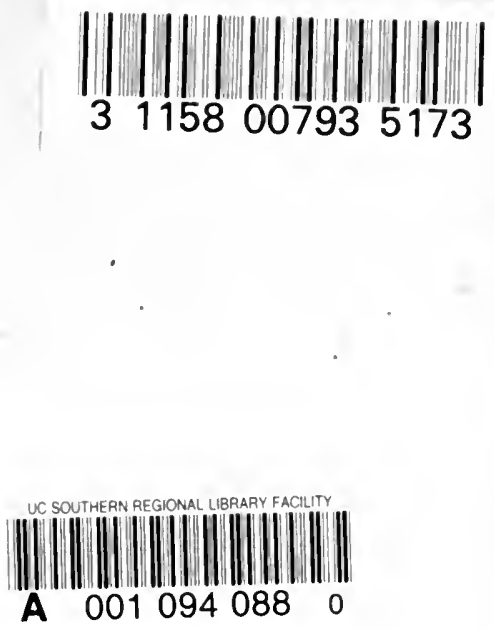
